OPEN ACCESS

Edited by:

Junichi Chikazoe, National Institute for Physiological

Sciences (NIPS), Japan

Reviewed by:

Robert J. Lee,

University of Pennsylvania,

United States

Linda Barlow,

University of Colorado Anschutz

Medical Campus, United States

${ }^{*}$ Correspondence:

Mathias Hafner

m.hafner@hs-mannheim.de

Rüdiger Rudolf

r.rudolf@hs-mannheim.de

Specialty section:

This article was submitted to Sensory Neuroscience,

a section of the journal

Frontiers in Human Neuroscience

Received: 14 February 2021

Accepted: 20 May 2021

Published: 22 June 2021

Citation:

von Molitor E, Riedel K, Krohn M, Hafner $M$, Rudolf $R$ and Cesetti $T$

(2021) Sweet Taste Is Complex:

Signaling Cascades and Circuits

Involved in Sweet Sensation.

Front. Hum. Neurosci. 15:667709.

doi: 10.3389/fnhum.2021.667709

\section{Sweet Taste Is Complex: Signaling Cascades and Circuits Involved in Sweet Sensation}

\author{
Elena von Molitor ${ }^{1}$, Katja Riedel' ${ }^{2}$, Michael Krohn ${ }^{2}$, Mathias Hafner ${ }^{1 *}$, Rüdiger Rudolf ${ }^{1,3 *}$ \\ and Tiziana Cesetti ${ }^{1}$ \\ ${ }^{1}$ Institute of Molecular and Cell Biology, Hochschule Mannheim, Mannheim, Germany, ${ }^{2}$ BRAIN AG, Zwingenberg, Germany, \\ ${ }^{3}$ Interdisciplinary Center for Neurosciences, Heidelberg University, Heidelberg, Germany
}

Sweetness is the preferred taste of humans and many animals, likely because sugars are a primary source of energy. In many mammals, sweet compounds are sensed in the tongue by the gustatory organ, the taste buds. Here, a group of taste bud cells expresses a canonical sweet taste receptor, whose activation induces $\mathrm{Ca}^{2+}$ rise, cell depolarization and ATP release to communicate with afferent gustatory nerves. The discovery of the sweet taste receptor, 20 years ago, was a milestone in the understanding of sweet signal transduction and is described here from a historical perspective. Our review briefly summarizes the major findings of the canonical sweet taste pathway, and then focuses on molecular details, about the related downstream signaling, that are still elusive or have been neglected. In this context, we discuss evidence supporting the existence of an alternative pathway, independent of the sweet taste receptor, to sense sugars and its proposed role in glucose homeostasis. Further, given that sweet taste receptor expression has been reported in many other organs, the physiological role of these extraoral receptors is addressed. Finally, and along these lines, we expand on the multiple direct and indirect effects of sugars on the brain. In summary, the review tries to stimulate a comprehensive understanding of how sweet compounds signal to the brain upon taste bud cells activation, and how this gustatory process is integrated with gastro-intestinal sugar sensing to create a hedonic and metabolic representation of sugars, which finally drives our behavior. Understanding of this is indeed a crucial step in developing new strategies to prevent obesity and associated diseases.

Keywords: sweet taste receptor, signaling, gustducin, calcium, GLP-1, gastro-intestinal tract, brain

\section{INTRODUCTION}

\section{Increased Sugar Consumption Causes Severe Health Problems}

Sugars, as a prime source of calories, are used for metabolic energy production. Perhaps as a consequence of this, sweet taste is one of the most passionate sensations humans experience (DiNicolantonio et al., 2018). Already the human fetus has a preference for sweet compounds present in the amniotic fluid, and neonates show responses to sweet solutions (Tatzer et al., 1985; 
Steiner et al., 2001) (for review Beauchamp and Mennella, 2011; Ventura and Mennella, 2011). Sugar attraction is generally driven by the activation of brain reward pathways (Araujo et al., 2012; Kendig, 2014; for review Han et al., 2019; Gutierrez et al., 2020) and may lead to addictive behavior (Kendig, 2014). The strong attraction to sugars is partly learned (Veldhuizen et al., 2007) and influenced by many factors, such as other sensory inputs (Ohla et al., 2012) (for review Small, 2012), emotions (Noel and Dando, 2015) and the internal metabolic state (Zhang et al., 2018). Furthermore, also genetics may influence individual variability in sweet taste preference (Keskitalo et al., 2007; Bachmanov et al., 2014).

Only 200 years ago, industrialization and colonial trading increased the global sugar availability by distributing the yield of large sugar cane fields to the world (Tappy, 2012; Chow, 2017). Since then, the consumption of the once luxury product increased steadily. Initially used to sweeten beverages such as tea, coffee and coco, the fabrication of chocolate bars, icecreams and sodas started in the 20th century (Tappy, 2012). Nowadays, sugar has conquered virtually all food suppliers over the world (DiNicolantonio et al., 2018), and sugar consumption increased from $5 \mathrm{~kg} /$ person/year in 1800, to $70 \mathrm{~kg} /$ person/year in 2006 (Tappy, 2012). This has contributed to obesity and has become a main risk factor for many chronic disorders including type-2 diabetes, cardiovascular diseases and metabolic syndrome (Bray and Popkin, 2014; Borges et al., 2017; Chow, 2017; Kochem, 2017). However, in contrast to amino acids or fats, which are essential for the body, there is no strict physiological requirement for sugar consumption (Westman, 2002; DiNicolantonio et al., 2018).

To fight the present sugar overload, much effort has been put into finding sugar substitutes, such as non-caloric sweeteners, which are sweet, but contain no calories (Pepino, 2015). Today, there are seven principal non-caloric sweeteners on the market: advantame, saccharin, aspartame, sucralose, cyclamate, neotame and acesulfame $\mathrm{K}^{+}$, whose daily acceptable intake dosage is approved by the FDA (Pepino, 2015). However, some of the sweeteners are known for their unpleasant bitter off-taste (Moskowitz and Klarmann, 1975; Kuhn et al., 2004; Galindo-Cuspinera et al., 2006). Although their safety has been clinically assessed (FDA/EFSA) (summarized in BfR Background Information from Bundesinstitut für Riskobewertung, 2014), recent studies suggest that they may increase the risk of cancer, obesity and diabetes. A probable reason for these unexpected side effects might be the activation sweet taste receptors in many extraoral tissues (for review Yamamoto and Ishimaru, 2013; Laffitte et al., 2014). Thus, understanding sweet taste signaling, including its effect in the gastro-intestinal tract and the brain, might help to mitigate the sugar dominance and improve global health.

\section{Structure of the Taste Buds}

According to the current knowledge, sweet taste is first sensed by the taste buds, i.e., gustatory organs, which are formed by roughly 100 specialized taste bud cells each (Lindemann, 1996; Montmayeur, 2002; Roper and Chaudhari, 2017). Humans possess about 5,000 taste buds (Suzuki, 2007; Witt, 2019). Taste bud cells can be grouped into four types (I-IV), defined by their morphology, function and expression profile (for review Roper, 2013): type I cells, with glia-like function; type II (receptor) cells, which stimulate the gustatory nerve terminals via unconventional ATP release upon detection of umami, bitter or sweet stimuli (Finger et al., 2005; Huang et al., 2007); type III cells, which transduce sour taste and make functional synapses with the afferent gustatory nerve fibers (Finger, 2005; DeFazio et al., 2006; Roper, 2013) and finally, type IV basal cells, which serve as progenitor cells (Ren et al., 2014) to replenish mature taste bud cells, as these possess a limited life span (in rodents, half-live varies form 8 to 22 days according to the cell type) (Chaudhari and Roper, 2010; Perea-Martinez et al., 2013; Liman et al., 2014; Barlow, 2015). More recently, a group of broadly responding taste bud cells has been characterized which have a type III phenotype, but respond to multiple gustatory stimuli (Dutta Banik et al., 2020). In mammals, taste buds are located in specialized papillae all over the tongue, epiglottis and palate (Lindemann, 1999; Montmayeur, 2002; Witt, 2019). Fungiform papillae, in the anterior tongue, are innervated by the chorda tympani nerve, a branch of the cranial nerve VII. Circumvallate papillae are located on the dorsal tongue and are in contact with the glossopharyngeal nerve (cranial nerve IX) (Scott, 2005; Kikut-Ligaj and Trzcielińska-Lorych, 2015). Foliate papillae, on the lateral sides of the tongue, are innervated by both nerves (Montmayeur, 2002; Witt, 2019). In the larynx there are taste buds and also single taste cells, which are in contact with the superior laryngeal branch of the vagus nerve (X) (Jowett and Shrestha, 1998; Sbarbati et al., 2004). In addition, sweet compounds stimulate the gastro-intestinal system, the brain, and other organs, either directly or indirectly via gustatory mechanisms (for review von Molitor et al., 2020c). Reciprocal cross talk occurs between oral sweet-sensation and visceral homeostatic signals. Indeed, intestinal hormones and neuropeptides have been identified in taste buds and shown to modulate taste bud cells activity (for review Dotson et al., 2013). In particular, glucagon-like-peptide 1 (GLP-1), leptin and endocannabinoids modulate sweet taste responses (Ninomiya et al., 2002; Shin et al., 2008; Martin et al., 2009; Niki et al., 2010; Martin et al., 2012).

\section{Studying Taste in Human}

Studies on taste transduction in human have progressed slowly for many reasons: (1) taste bud cells make up less than $1 \%$ of the tongue, (2) human samples are rare, and (3) primary taste bud cells have a short life span (Liman et al., 2014; Barlow, 2015). Therefore, assessment of human taste physiology has been mostly carried out by in vivo "taste sensitivity measurements" which probe the ability of subjects to taste a certain stimulus and determine its quality (Reed and McDaniel, 2006; Aleman et al., 2016). Such tests fall into different categories. In "quality tests" only the taste modality is defined (Galindo-Cuspinera et al., 2006; Zhang et al., 2009). In "detection threshold tests" the lowest concentration of a tastant that a subject can recognize is determined (Reed and McDaniel, 2006; Zhang et al., 2009). In "intensity tests," participants evaluate the sweetness of molecules by ranking them in a hierarchical order, often relative to a 
standard (Reed and McDaniel, 2006). Alternatively, sweet taste can be analyzed using "hedonic assessment" (Reed and McDaniel, 2006), where people rate how pleasant a compound is (KampovPolevoy et al., 1997) and if it is preferred over another one (Liem and Mennella, 2002; Reed and McDaniel, 2006). Until now, assays to understand the underlying intracellular signaling and/or neuronal pathways are very difficult to pursue in humans. However, the sweet taste receptor inhibitor lactisol has been used in humans to investigate the perception of polysaccharides (Lapis et al., 2016; Schweiger et al., 2020). Further, a blue food-dye (Robert's Brilliant Blue FCF133) can be used for live staining of tongue papillae in humans (Shahbake et al., 2005; Zhang et al., 2009; Gardner and Carpenter, 2019). In addition, with brain imaging techniques, such as MRI (magnetic resonance imaging) and PET (positron emission tomography), the brain regions activated by sweet stimuli have been mapped in humans (Prinster et al., 2017; Canna et al., 2019; Avery et al., 2020) (for review Han et al., 2019).

Due to these limitations, taste-related signaling mechanisms have been studied mainly in rodents, although there are major species-related differences. For example, rodents have a much stronger preference for polysaccharides compared to humans (Feigin et al., 1987). Further, certain sweet taste receptor inhibitors are species specific, such as gurmarin for rodents and lactisol for humans (Hellekant, 1976; Hellekant et al., 1988; Jiang et al., 2005). An alternative experimental system consists in mammalian cell lines heterologously expressing the human sweet taste receptor and its downstream signaling molecules. In this case however, the native cellular background and the niche are missing (von Molitor et al., 2020b). Thus, a new approach, based on organoids derived from mouse taste progenitor cells, may resemble more closely the native environment (Ren et al., 2009, 2010, 2014, 2017) and organoids could be theoretically also generated from human papillae. Another recent approach consists in the generation of a stably proliferating cell line from human lingual cells, that can be used to produce 3D-cell cultures, such as spheroids (Hochheimer et al., 2014; von Molitor et al., 2020a). Thus, an optimal model to study sweet taste transduction, especially in human, has still to be established.

\section{A LONG WAY TO THE DISCOVERY OF THE SWEET TASTE RECEPTOR}

Long before the major components of taste transduction pathways were unraveled, Hänig showed that different tongue areas were more sensitive to certain taste modalities (Hanig, 1901). Unfortunately, many years later his experimental linegraph was redrawn in a simplified and mispresenting manner (Boring, 1942), leading to the common and long-lasting erroneous belief that the five taste modalities (sweet, bitter, umami, sour, salt) map to distinct tongue areas (Schiffman et al., 1986; Hoon et al., 1999). Finally, in 1974, evidence was provided that each taste modality can be sensed on every tongue part, but with different detection thresholds (Collings, 1974). Regarding sweetness, the nerve with the highest sensitivity is the glossopharyngeal in rats (Krimm et al., 1987), and chorda tympani in mice and rhesus monkeys (Hellekant et al., 1997; Danilova and Hellekant, 2003). In humans, since nerve recordings are not possible, contrasting results were obtained: the sweet detection threshold was reported to be lower either at the posterior tongue (Dastur, 1961; Okuda and Tomita, 1976) or at the tongue tip (Collings, 1974), while others reported no spatial difference (Nilsson, 1979; Sato et al., 2002). Nonetheless, subregional differences were detected even within the anterior tongue, with the edge and the lateral regions being the most sweet-sensitive areas (Stein et al., 1994). A reason for the divergence could be the heterogeneity of subjects, since taste is influenced by age (Stein et al., 1994; Ng et al., 2004), genetic variance (Bachmanov et al., 2014; Eriksson et al., 2019; Hwang et al., 2019), sex (Than et al., 1994; Fushan et al., 2010), diseases (Ng et al., 2004), and temperature (Talavera et al., 2005; Lemon, 2015).

Before the sweet taste receptor was discovered, sweet transduction in taste bud cells was proposed to involve cyclic adenosine monophosphate (cAMP) and protein-kinase A (PKA). In general, $\mathrm{cAMP}$ levels are regulated by its synthesis via adenyl cyclases (ACs) and hydrolysis via phosphodiesterases (PDEs) (Trubey et al., 2006). Already in 1972, a high AC activity was found in bovine tongue epithelium, enriched in taste buds (Kurihara and Koyama, 1972). Consistently, rat taste bud cells express AC 4,5 and 8 (Abaffy et al., 2003; Trubey et al., 2006). Sugars and saccharin were shown to stimulate AC in the presence of guanine nucleotides in frog, rat and pig tongue epithelium (Avenet and Lindemann, 1987; Striem et al., 1989; Naim et al., 1991; Striem et al., 1991). Electrophysiology studies revealed that application of cAMP analogs caused taste bud cell depolarization due to reduced $\mathrm{K}^{+}$outward currents via PKA-dependent phosphorylation (Avenet and Lindemann, 1987; Tonosaki and Funakoshi, 1988; Striem et al., 1991). Consistently, in rat and hamster taste bud cells, saccharin and sucrose elicited depolarization and generated action potentials, an effect that was mimicked by the application of a permeable analog of cAMP and cGMP and did not require extracellular $\mathrm{Ca}^{2+}$ (Béhé et al., 1990; Cummings et al., 1993). A different mechanism was unraveled in frog taste bud cells where saccharin and NC01 stimulation resulted in PDE-mediated cAMP hydrolysis, which in turn activated a cyclic-nucleotide-suppressible channel (CNG), mediating $\mathrm{Ca}^{2+}$ influx and cell depolarization (Kolesnikov and Margolskee, 1995). A direct proof of sweet-mediated cAMP/PKA pathway activation in taste bud cells is therefore still missing, hampered at that time by technical limitations, and later on possibly neglected.

In 2001, a big breakthrough was finally achieved, when multiple groups identified the "sweet taste receptor": a heterodimer formed by two G-protein coupled receptor (GPCR) subunits, T1R2 and T1R3, located at the taste pore of type II taste bud cells (Hoon et al., 1999; Bachmanov et al., 2001; Kitagawa et al., 2001; Max et al., 2001; Montmayeur et al., 2001; Nelson et al., 2001; Li et al., 2002) (for review Temussi, 2006; DuBois, 2016). This discovery was based on the observation that two mouse strains, called tasters (C57BL/6 and DBA/2), were strongly attracted by saccharin and D-phenylalanine (Bachmanov et al., 1997). Sac and $d p a$, which are both located 
on chromosome 4, were identified as the main loci determining sweet preference in mice (Fuller, 1974; Capeless and Whitney, 1995; Lush et al., 1995; Max et al., 2001; Margolskee, 2002; Shigemura et al., 2005). Consistently, both genes were found to influence peripheral nerve response to sucrose (Bachmanov et al., 1997). The first sweet-related subunit cloned was T1R2, however, its function was not clear at that time (Hoon et al., 1999). Soon afterward, Tas1r3, the gene encoding the T1R3 subunit, was mapped on the human chromosome 1p36, and based on this sequence the murine ortholog was found in the Sac locus (Fuller, 1974; Lush, 1989; Lush et al., 1995; Kitagawa et al., 2001; Montmayeur et al., 2001; Nelson et al., 2001; Sainz et al., 2001). Commonly, heterodimers of T1R2 and T1R3 form functional sweet taste receptors, as demonstrated with recombinant systems (Nelson et al., 2001; Li et al., 2002; Zhao et al., 2003) and transgenic mouse models (Zhao et al., 2003). The T1R family contains one additional subunit: T1R1, that forms with T1R3 the umami receptor (Nelson et al., 2001; Zhao et al., 2003). All three T1R subunits belong to the class C GPCRs. Immunostainings and in situ hybridization in mouse tongue revealed the expression of T1R3 in about one third of taste bud cells in almost all papillae (Table 1; Nelson et al., 2001). Even if bitter- (T2R) and sweet taste receptors (T1R2/T1R3) were both present in type II cells, their expression did not overlap (Nelson et al., 2001). Furthermore, also sweet (T1R2) and umami (T1R1) specific subunits were mainly present in distinct type II cell populations (Hoon et al., 1999; Stone et al., 2007). Interestingly, fitting the old observations of Hänig, regional differences in the expression were recognized (Table 1). In rodents, T1R3 was present in all papillae, but the strongest expression was observed in circumvallate and foliate papillae, where also T1R2 showed the highest and almost exclusive expression (Montmayeur et al., 2001; Nelson et al., 2001) (for review Montmayeur, 2002). In human, T1R3 was detected in circumvallate and fungiform papillae (Max et al., 2001). Thus, the heterodimeric T1R2/T1R3
GPCR was recognized as the main molecular sensor for sugars and other sweet compounds.

\section{SWEET TASTE RECEPTOR MEDIATED TRANSDUCTION}

Not only natural sugars, such as monosaccarides or disaccharides, activate the sweet taste receptor, but also ligands with very different chemical structures, such as amino acids, proteins and non-caloric sweeteners (McCaughey, 2008), may bind to different domains of T1R2/T1R3 (Sainz et al., 2007; DuBois, 2016). In particular, in transgenic cells and animals it was shown that the human T1R2 (hT1R2) confers sensitivity to aspartame, glycyrrhizic acid, monellin and thaumatin (Zhao et al., 2003), while hT1R3 contains a binding site for neohesperidin dihydrochalcone ( $\mathrm{Li}$ et al., 2002). It is not yet clear if also oligosaccharides, such as starch, are able to activate the sweet taste receptor (Lapis et al., 2016; Schweiger et al., 2020). In general, the change in the sweet taste receptor conformation upon ligand binding activates an intracellular downstream signaling.

\section{The Canonical Signaling Pathway for Sweet and Bitter Taste}

Sweet and bitter transduction pathways have been discovered in parallel and they share many components. In human, bitter compounds bind to a variety of $\sim 25$ different receptors of the $\mathrm{T} 2 \mathrm{R}$ family, that can form both homomeric and heteromeric complexes (Kuhn et al., 2004; Kuhn and Meyerhof, 2013). T2R activation leads to the release of the $\beta_{3} \gamma_{13}$ subunit (Huang et al., 1999; Rössler et al., 2000) from the associated G-protein, which then activates phospholipase C $\beta 2$ (PLC $\beta 2$ ) (Rössler et al., 1998; Miyoshi et al., 2001; Yan et al., 2001; Zhang et al., 2003) to generate inositol-3-phosphate (IP3) (Rössler et al., 1998; Miyoshi et al., 2001; Yan et al., 2001; Zhang et al., 2003). Subsequently,

TABLE 1 | Expression of the sweet taste receptor subunits (T1R2/T1R3) in mammal taste papillae.

\begin{tabular}{|c|c|c|c|c|c|c|}
\hline Subunit & $c V$ & Fungiform & Foliate & Palatal & Species & Source \\
\hline \multirow[t]{8}{*}{ T1R3 } & strong & strong & strong & & Mouse & Kitagawa et al., 2001 \\
\hline & $\sim 30 \%$ cells & $\sim 30 \%$ cells & $\sim 30 \%$ cells & $\sim 30 \%$ cells & Mouse & Nelson et al., 2001 \\
\hline & $24 \%$ cells & $15 \%$ cells & $14 \%$ cells & & Mouse & Montmayeur et al., 2001 \\
\hline & strong & strong & strong & & Mouse & Max et al., 2001 \\
\hline & $20 \%$ cells & $20 \%$ cells & & & Human & Max et al., 2001 \\
\hline & $100 \%$ TB, $23 \%$ cells & $<4 \% \mathrm{~TB},<1 \%$ cells & $100 \%$ TB, $26 \%$ cells & & Mouse & Sainz et al., 2001 \\
\hline & strong & no & Less strong & No & Mouse & Matsunami et al., 2000 \\
\hline & $6288 \times 10^{-7}$ & $150600 \times 10^{-7}$ & $30 \times 10^{-7}$ & & Mouse & Choi et al., 2016 \\
\hline \multirow[t]{6}{*}{$T 1 R 2$} & all TBs $20-30 \%$ cells & $0.5 \%$ cells & abundant & few & Rat & Hoon et al., 1999 \\
\hline & yes & yes & yes & & Mouse & Nelson et al., 2001 \\
\hline & yes & no & yes & & Mouse & Kitagawa et al., 2001 \\
\hline & strong & low & strong & & Mouse & Montmayeur et al., 2001 \\
\hline & strong & less strong & few & few & Mouse & Matsunami et al., 2000 \\
\hline & $7180 \times 10^{-7}$ & $21 \times 10^{-7}$ & $1170 \times 10^{-7}$ & & Mouse & Choi et al., 2016 \\
\hline
\end{tabular}

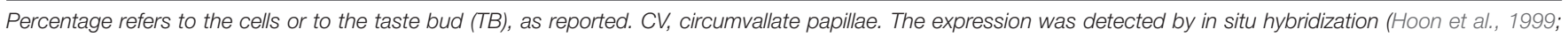

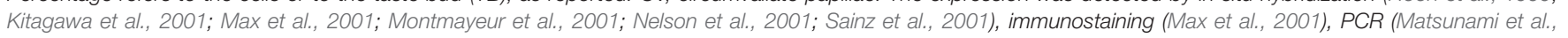
2000), and qPCR (Choi et al., 2016). 
IP3 binds to its receptor (IP3R) on the endoplasmic reticulum (Clapp et al., 2001; Miyoshi et al., 2001) and induces $\mathrm{Ca}^{2+}$ release from the stores (Akabas et al., 1988). Increased cytoplasmic $\mathrm{Ca}^{2+}$ levels in turn open the membrane-associated transient receptor potential channel (TRPM5) (Pérez et al., 2002; Zhang et al., 2003) permitting $\mathrm{Na}^{+}$influx, followed by cell depolarization and ATP release via CALHM1/3 channel (Taruno et al., 2013; Table 2 and Figure 1). The signaling network downstream the sweet taste receptor involves the same key players (Table 2) and it is known as the "canonical pathway." The functional role of these signaling molecules has been tested in several knockout mouse models, which displayed abolished or reduced nerve and behavioral responses to sweet compounds (Table 2) (for review von Molitor et al., 2020c).

\section{Sweet Transduction May Involve Multiple G-proteins}

The first described G-protein coupled to the sweet taste receptor was gustducin: a G-protein related to the $G_{i}$ family, which consists of $\mathrm{G} \alpha$-gustducin $\left(\mathrm{G} \alpha_{\text {gust }}\right)$ and $\mathrm{G} \beta_{3} \gamma_{13}$ (McLaughlin et al., 1992; Huang et al., 1999). Gustducin is specifically expressed in the taste papillae and is closely related to the retinal transducin (McLaughlin et al., 1992; Margolskee, 1993). Gustducin and transducin share $80 \%$ sequence identity and many features, such as interaction with $\beta \gamma$ subunits, GTPase activity and PDE activation (McLaughlin et al., 1993; Hoon et al., 1995; Ruiz-Avila et al., 1995). A taste specific PDE was found in bovine and rat taste tissue, and gustducin was shown to be interchangeable with transducin in a recombinant baculovirus system (Law and Henkin, 1982; McLaughlin et al., 1994; Ruiz-Avila et al., 1995). In taste buds, the expression ratio transducine/gustducin is $1 / 25$ (McLaughlin et al., 1993;

TABLE 2 | Overview of signaling molecules involved in bitter and sweet signaling.

\begin{tabular}{lll}
\hline $\begin{array}{l}\text { Signaling } \\
\text { molecule }\end{array}$ & Bitter & Sweet \\
\hline$G \beta_{3}$ & Rössler et al., 2000 & Max et al., 2001 \\
$G \gamma_{13}$ & Huang et al., 1999 & Max et al., 2001 \\
PLCB2 & Rössler et al., 1998; & Asano-Miyoshi et al., 2000; \\
& Miyoshi et al., 2001; Yan & Max et al., 2001; Miyoshi \\
& et al., 2001; Zhang et al., & et al., 2001; Zhang et al., \\
& 2003 & 2003 \\
IP3 & Hwang et al., 1990; Ogura & Bernhardt et al., 1996; \\
& et al., 1997; Spielman, & Uchida and Sato, 1997; \\
& 1998; Huang et al., 1999 & Usui-Aoki et al., 2005 \\
IP3R & Clapp et al., 2001; Miyoshi & Miyoshi et al., 2001 \\
& et al., 2001 & \\
Ca ${ }^{2+}$ release & Akabas et al., 1988 & Bernhardt et al., 1996; \\
from stores & & Uchida and Sato, 1997 \\
TRPM5 & Pérez et al., 2002; Zhang & Pérez et al., 2002; Zhang \\
& et al., 2003 & et al., 2003; Talavera et al., \\
& & 2005 \\
\end{tabular}

Involvement of the signaling molecules was demonstrated with knockout mouse models, where $\mathrm{Ca}^{2+}$ signals in taste bud cells, nerve responses and/or behavioral attraction were measured upon stimulation. Immunostainings were used for localization of the signaling molecules.
Hoon et al., 1995; Ruiz-Avila et al., 1995). The strongest evidence that the sweet taste receptor can functionally couple to $\mathrm{G} \alpha_{\text {gust }}$ comes from experiments in recombinant systems, where T1R2/T1R3 was coexpressed with $G \alpha_{15}$ or the artificial chimeric $\mathrm{G} \alpha_{16}$ subunit derived from murine hematopoietic cells (Nelson et al., 2001, 2002). Still, the functional coupling of $\mathrm{G} \alpha_{\text {gust }}$ and the sweet taste receptor in native taste tissue is an open issue, as sucrose and non-caloric sweeteners were unable to activate gustducin in bovine taste membrane extract (Ruiz-Avila et al., 1995; Ming et al., 1998).

Further observations suggested that gustducin may be one, but not the only player in sweet taste transduction, since: (1) only a subset of sweet taste receptor expressing cells are positive for gustducin, with publications reporting from $1 / 10$ to $2 / 3$ of double positive cells (Hoon et al., 1999; Montmayeur et al., 2001; Max et al., 2001), and (2) in gustducin-knockout mice the responses to sweet compounds were reduced but not abolished (Wong et al., 1996; Ruiz-Avila et al., 2001; He et al., 2002; Danilova et al., 2006). Regarding $G \alpha_{\text {gust }}$ expression, regional differences occur and they are species-specific. In rats, taste buds of the fungiform papillae contain three time less gustducin-positive cells than those of the circumvallate papillae and the palate (Boughter et al., 1997). By contrast, in mice, G $\alpha_{\text {gust }}$ is coexpressed with T1R2/T1R3 in fungiform papillae and palatal taste bud cells, but not in the circumvallate papillae (Kim et al., 2003; Stone et al., 2007). This is consistent with the observation that in gustducin-knockout mice electrophysiological recordings from the chorda tympani nerve, showed an almost abolished response to sweet compounds (Wong et al., 1996), while the response of the glossopharyngeal nerve was less affected (Danilova et al., 2006). This suggests that sweet taste transduction may use different pathways according to the location of the taste bud cells, with species-specific differences. Little can be said about gustducin's functional role in humans as there is only one immunostaining study showing its expression in circumvallate and foliate papillae (Takami et al., 1994).

Gustducin is activated when an agonist binds to a bitter-, sweet- or umami-taste receptor. The conformational change of the GPCR induces GDP/GTP exchange on the G $\alpha$ subunit, which then dissociates to transduce the signal into the cell (Hoon et al., 1995). For bitter stimuli, the $G \alpha$ and $\beta \gamma$ subunits were proposed to activate distinct downstream effector molecules (Sainz et al., 2007): $\mathrm{G} \alpha$ may induce PDE-mediated cAMP hydrolysis, while $\beta \gamma$ may activate PLC $\beta 2 /$ IP3 signaling (Yan et al., 2001). Further, gustducin-knockout mice had elevated basal cAMP levels and bitter responses were unmasked only upon inhibition of PKA (Clapp et al., 2008), proposing that $\mathrm{G}_{\text {gust }}$ activates PDEs and is important to maintain low levels of cAMP in resting states (Lindemann, 1996; Spielman, 1998; Clapp et al., 2008). Unfortunately, this scenario was not investigated for sweet taste responses therefore, we can only speculate whether the sweetmediated pathway similarly requires gustducin to expand the functional range of cAMP changes. Nevertheless, this hypothesis provides a framework for understanding the reduced sweet preference in gustducin-knockout mice (Wong et al., 1996).

The picture is further complicated by the fact that additional G-proteins have been found in taste bud cells (Table 3). 


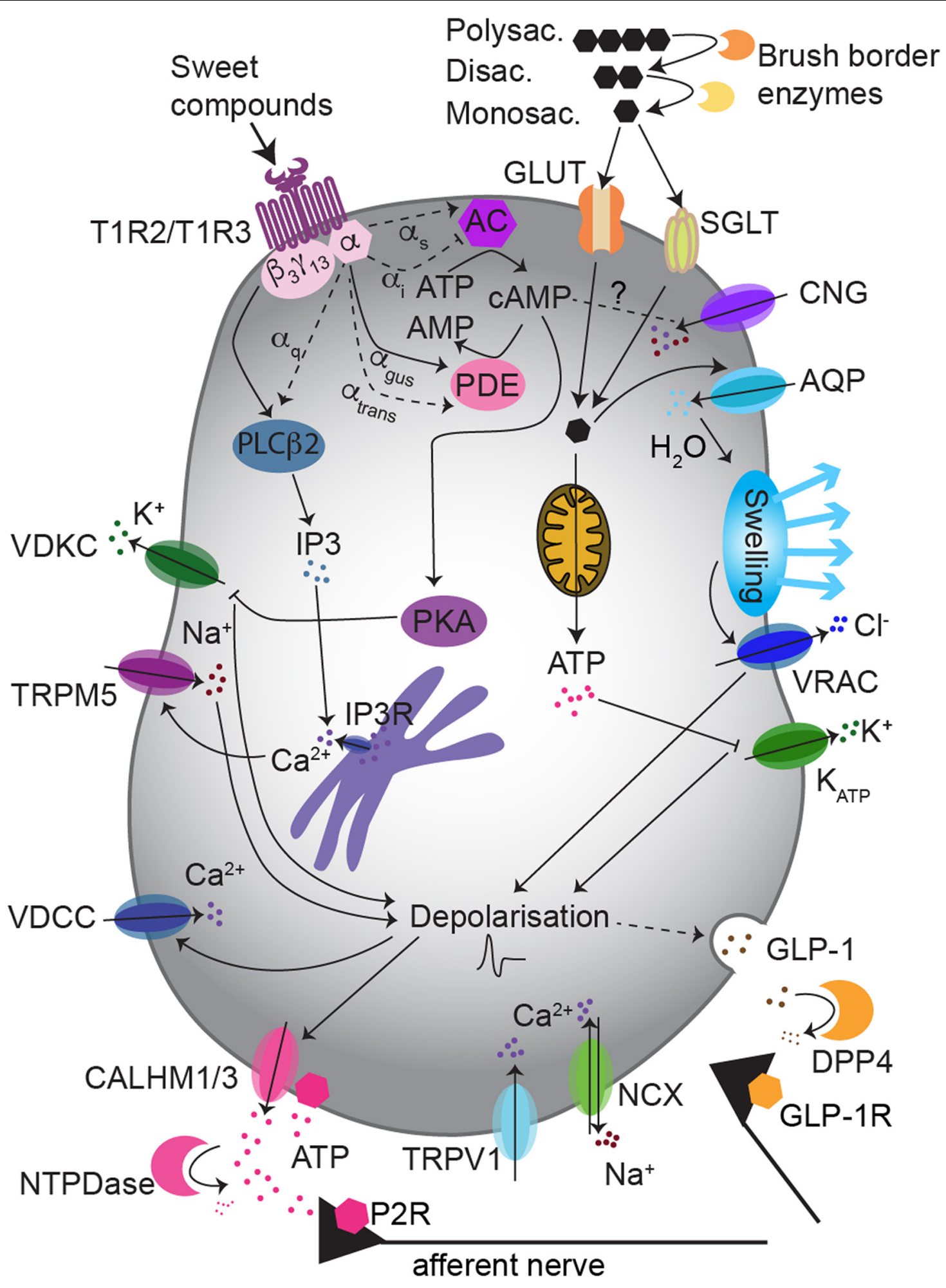

FIGURE 1 | Sweet taste transduction uses multiple pathways in type II taste bud cells. The "canonical pathway" implies the activation of gustducin by T1R3/T1R2 receptor, which then promotes: intracellular $\mathrm{Ca}^{2+}$ rise via PLC $\beta 2 / I P 3$ signaling, cell depolarization via TRPM5 and ATP release. Non-caloric sweeteners may preferentially use the PLCB2/IP3 pathway, while sugars may rather activate a cAMP/PKA pathway, depolarizing the cell via $\mathrm{K}^{+}$channels inhibition. The "alternative

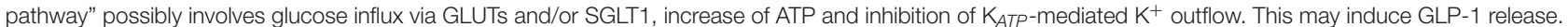
Abbreviations: AQP, aquaporins; DPP4, dipeptidyl peptidase 4; CALHM1/3, $\mathrm{Ca}^{2+}$ homeostasis modulator 1/3; VDKC, voltage-dependent $\mathrm{K}^{+}$channel; P2R, purinergic receptor class 2; GLP-1R, GLP-1 receptor. 
TABLE 3 | Overview of G-protein subunits expression in the taste buds.

\begin{tabular}{|c|c|c|}
\hline $\begin{array}{l}\text { Trimeric G } \\
\text { proteins }\end{array}$ & Species & Source \\
\hline \multirow[t]{4}{*}{$G \alpha_{\text {gust }}$} & $\begin{array}{l}\text { Recombinant in } \\
\text { baculovirus }\end{array}$ & Hoon et al., 1995 \\
\hline & Mouse & $\begin{array}{l}\text { Wong et al., 1996; Huang } \\
\text { et al., 1999; Ruiz-Avila } \\
\text { et al., 2001; He et al., 2002; } \\
\text { Kim et al., 2003; Danilova } \\
\text { et al., 2006; Miura et al., } \\
\text { 2007; Stone et al., } 2007\end{array}$ \\
\hline & Rat & $\begin{array}{l}\text { McLaughlin et al., 1992, } \\
\text { 1994; Yang et al., 1999; } \\
\text { Kusakabe et al., } 2000\end{array}$ \\
\hline & Human & Max et al., 2001 \\
\hline \multirow[t]{3}{*}{$G \alpha_{\text {trans }}$} & Mouse & He et al., 2002 \\
\hline & Rat & $\begin{array}{l}\text { Ruiz-Avila et al., 1995; } \\
\text { Yang et al., } 1999\end{array}$ \\
\hline & Bovine & Ruiz-Avila et al., 1995 \\
\hline$G \alpha_{S}$ & Rat & $\begin{array}{l}\text { McLaughlin et al., } 1992, \\
\text { 1994; Kusakabe et al., } \\
2000\end{array}$ \\
\hline$G \alpha_{i-2}$ & Rat & $\begin{array}{l}\text { McLaughlin et al., 1992, } \\
\text { 1994; Asano-Miyoshi et al., } \\
\text { 2000; Kusakabe et al., } \\
2000\end{array}$ \\
\hline$G \alpha_{i-3}$ & Rat & $\begin{array}{l}\text { McLaughlin et al., 1992, } \\
\text { 1994; Kusakabe et al., } \\
2000\end{array}$ \\
\hline$G \alpha_{i-4}$ & Rat & $\begin{array}{l}\text { McLaughlin et al., 1992, } \\
1994\end{array}$ \\
\hline$G \alpha_{12}$ & Rat & $\begin{array}{l}\text { McLaughlin et al., 1992, } \\
1994\end{array}$ \\
\hline$G \alpha_{15}$ & Mouse & $\begin{array}{l}\text { Shindo et al., 2008; } \\
\text { Tizzano et al., } 2008\end{array}$ \\
\hline$G \alpha_{q}$ & Rat & Kusakabe et al., 1998 \\
\hline$\beta_{3} \gamma_{13}$ & Mouse, human & Huang et al., 1999 \\
\hline$\beta_{3} \gamma_{13}$ & Rat & Rössler et al., 2000 \\
\hline
\end{tabular}

The expression was detected by immunofluorescence (Ruiz-Avila et al., 1995; Kusakabe et al., 2000; Max et al., 2001; Shindo et al., 2008), in situ hybridization (Yang et al., 1999; Kusakabe et al., 2000; Kim et al., 2003; Shindo et al., 2008), PCR (Kusakabe et al., 1998; Tizzano et al., 2008), Southern (Kusakabe et al., 2000), and Northern blot (Kusakabe et al., 1998), as well as gene expression profiling (Huang et al., 1999).

Besides $\mathrm{G} \alpha_{\text {gust }}$, also the mRNA for $\mathrm{G} \alpha_{i-2}, \mathrm{G} \alpha_{i-3}, \mathrm{G} \alpha_{s}$ and $\mathrm{G} \alpha_{14}$ was found in rat taste tissue (McLaughlin et al., 1992). Immunostaining analysis showed that also $\mathrm{G} \alpha_{15}$ and $\mathrm{G} \alpha_{q}$ were localized in rat taste buds (Kusakabe et al., 1998). The expression of $\mathrm{G} \alpha_{i-2}, \mathrm{G} \alpha_{i-3}, \mathrm{G} \alpha_{s}$, and $\mathrm{G} \alpha_{\text {gust }}$ was confirmed in rat circumvallate papillae with different techniques, proving that one taste bud cell can coexpress multiple $\mathrm{G} \alpha$ subunits, and $\mathrm{G} \alpha_{\text {gust }}$ may not be the dominant species (Kusakabe et al., 1998; Kusakabe et al., 2000). This finding suggests that different, mutually interacting pathways might coexist in individual taste bud cells. Conversely, other evidence supports the idea that multiple pathways may be segregated in different cell subpopulations: for example in mouse taste bud cells, $G \alpha_{14}$ was found to be coexpressed with T1R3, but not with gustducin (Shindo et al., 2008; Tizzano et al., 2008). The $\mathrm{G} \alpha_{14}$ subunit may be involved in PLC activation and IP3 generation (Kusakabe et al., 1998; Shindo et al., 2008; Tizzano et al., 2008). Based on a differential hybridization screen, $G \beta_{3} \gamma_{13}$ expression was detected in all $\mathrm{G} \alpha_{\text {gust }}$ positive receptor cells (Rebecchi and Pentyala, 2000). Additionally, also the $G \beta_{1} \gamma_{13}$ subunit was found in receptor cells, and stimulation with a bitter compound revealed its functionality (Huang et al., 1999). $\mathrm{G} \gamma_{13}$ colocalizes with $\mathrm{G} \alpha_{\text {gust }}$ and mediates production of IP3 via PLC $\beta 2$ upon bitter stimulation (Yan et al., 2001). Finally, also $G \gamma_{3}$ was found in taste bud cells, coexpressed with PLC $\beta 2, G \alpha_{\text {gust }}$ and G $\beta_{3}$ (Rössler et al., 2000). Hence, this plethora of observations suggests a heterogenous picture, with several G-proteins and multiple downstream signaling options involved in the sweet taste pathway.

In summary, it has been generally accepted that sweet taste transduction in taste bud cells is mediated by $\mathrm{G} \alpha_{\text {gust }}$. However, there are still many open questions, and several factors have to be considered in the interpretation of this transduction model: (1) functional studies are still very limited and mainly conducted in recombinant systems, (2) gustducin-knockout mice showed residual sweet taste responses, (3) besides $\mathrm{G} \alpha_{\text {gust }}$, also other $\mathrm{G} \alpha_{q}$ and $\mathrm{G} \alpha_{i}$ subunits have been found in taste bud cells (Table 3), (4) several second messengers are mobilized by sweet taste receptor activation. One could speculate that the relative importance of a certain signaling pathway varies among species. Indeed, in mice the $G \beta \gamma$ pathway may dominate, while in rats and hamsters the $\mathrm{G} \alpha$ pathway seems to be more prominent (Trubey et al., 2006). Therefore, it is likely that several G-proteins and different pathways are involved in sweet taste transduction, which may be similar for human sweet taste sensation as well.

\section{THE SWEET TASTE RECEPTOR-INDEPENDENT PATHWAY}

\section{Residual Sugar Attraction in Sweet Taste Receptor Deficient Mice}

After the discovery of the sweet taste receptor, it has been assumed that the taste of sugars and of non-caloric sweeteners is almost exclusively transduced via the heterodimer T1R2/T1R3. However, additional mechanisms mediating sugar perception in taste bud cells have been reported. Indeed, a small residual response to highly concentrated sugars, but not to non-caloric sweeteners, was observed in T1R2 and T1R3 single-knockout mice (Zhao et al., 2003). In another T1R3-knockout strain, no response to non-caloric sweeteners was observed, but chorda tympani responses to disaccharides were only moderately diminished and those to glucose were even preserved (Damak et al., 2003). Further evidence in favor of a sweet-sensing pathway independent of the classical sweet taste receptor, comes from knockout mice models for crucial downstream signaling molecules, such as PLC $\beta 2$ (Zhang et al., 2003; Dotson et al., 2005), TRPM5 (Zhang et al., 2003; Talavera et al., 2005; Damak et al., 2006; Sclafani et al., 2007; Ren et al., 2010; Eddy et al., 2012) or gustducin (Wong et al., 1996; He et al., 2002; Ruiz et al., 2003; Glendinning et al., 2005; Danilova et al., 2006; Sclafani et al., 2007), in which behavioral and nerve 
responses to sugars were not completely abolished (for review von Molitor et al., 2020c). Thus, it was proposed that, although the canonical T1R2/T1R3-mediated pathway is of principal importance for sweet sensation, additional sweet taste receptor independent pathways might sense caloric sugars (von Molitor et al., 2020c). These might employ T1R3 homodimers and/or completely different downstream signalings.

\section{The Sweet Taste Receptor Independent Pathway May Use Glucose Transporters}

In search of potential candidates for such alternative pathways, tissues involved in glucose homeostasis can be taken as models. Metabolic homeostasis in the body is achieved upon glucose absorption in the gastro-intestinal tract and glycemia regulation via pancreatic insulin release. Accordingly, gastro-intestinal and pancreatic cells use specialized mechanisms to sense and take up glucose. These include glucose transporters (GLUTs) and sodium-driven glucose symporters (SGLTs). The GLUT family contains 13 members with tissue-specific expression and functional diversity (Table 4). The SGLTs comprise only three family members (Scheepers et al., 2004; Zhao and Keating, 2007; Deng and Yan, 2016). In $\beta$-cells, GLUT2-mediated glucose entry elevates, via oxidative metabolism, the intracellular ATP level, which in turn leads to $\mathrm{K}_{A T P}$ channel inhibition (Ashcroft et al., 1984; Miki et al., 1998). This drives cell depolarization and triggers insulin release (Ashcroft, 2005; Yamamoto and Ishimaru, 2013; Laffitte et al., 2014). Alternatively, at hyperglycemic conditions, $\beta$-cell depolarization occurs via osmotic swelling and consequent activation of volume-regulated anion channels (VRACs), that mediates depolarizing outward $\mathrm{Cl}^{-}$currents (Matsumura et al., 2007; Best et al., 2010; Louchami et al., 2012). Conversely, SGLT1 activation directly depolarizes the cells since glucose entry is coupled to the influx of $\mathrm{Na}^{+}$. Furthermore, in contrast to GLUT, SGLT1 is activated also by non-metabolizable glucose analogs (Sclafani et al., 2020; Yasumatsu et al., 2020). In general, GLUTs and SGLT1 shuttle caloric sugars with different affinities (Table 3), but not non-caloric sweeteners. Considering the similarities between the taste papillae and the epithelia of the gastro-intestinal system (see chapter 7), the possibility that glucose transporters may be responsible for the residual response to sugars, as observed in sweet taste receptor deficient mice, was explored.

Notably, in human taste bud cells, glucose absorption has been long known (Kurosaki et al., 1998; Oyama et al., 1999; Toyono et al., 2011; Yee et al., 2011) and expression of both SGLT1 and GLUTs, was observed in taste papillae of different species (Table 4). Fittingly, also potential downstream players of GLUTs were found in taste bud cells (for review von Molitor et al., 2020c), supporting the hypothesis that GLUT and SGLT1 may be responsible for the residual glucose preference in T1R3-knockout mice (Damak et al., 2003). Specifically, the involvement of SGLT1 in T1R3-independent sugar responses in mice was recently reported. Yasumatzu et al. showed that $\mathrm{NaCl}$ selectively increased sweet responses to glucose and sucrose, but not to non-caloric sweeteners, nor to other taste modalities, both in wild type and T1R3-knockout mice (Yasumatsu et al., 2020). This increase was ablated by phlorizin, a SGLT1 blocker. Additionally, afferent sweet-responsive fibers showed three different response patterns to sweet stimuli: (1) fibers with a maximal response to sugars were sensitive to $\mathrm{NaCl}$ and phlorizin, (2) fibers with a maximal response to non-caloric sweeteners were unaffected by $\mathrm{NaCl}$ and phlorizin, and (3) fibers with a mixed behavior also responded to $\mathrm{NaCl}$ and phlorizin (Yasumatsu et al., 2020). This suggests that there are some sweet-responding taste bud cells expressing only SGLT1, some that express only $\mathrm{T} 1 \mathrm{R} 2 / \mathrm{T} 1 \mathrm{R} 3$ and a third group expressing both (Yasumatsu et al., 2020). Whether SGLT1-expressing cells represent type II or another cell population, such as the recently discovered "broadly responsive" cells, needs further investigation (Dutta Banik et al., 2020; Yasumatsu et al., 2020). It is still unknown if the SGLT1-mediated pathway induces $\mathrm{Ca}^{2+}$ signals,

TABLE 4 | GLUTs and SGLT expression in taste bud cells.

\begin{tabular}{|c|c|c|c|c|}
\hline Transporter & Substrate & Species & Papillae & Source \\
\hline GLUT4 (S/c2A4) & $\begin{array}{l}\text { glucose, dehydroacetic acid (Huang and Czech, 2007; } \\
\text { Vargas et al., 2019) }\end{array}$ & Mouse & $\mathrm{CV}$, foliate, fungiform & Yee et al., 2011 \\
\hline Glut5 (S/c2A5) & fructose (Douard and Ferraris, 2008) & Rat & CV & Merigo et al., 2011 \\
\hline Glut9 (S/c2A9) & glucose, fructose, urate (Doblado and Moley, 2009) & Mouse & $\mathrm{CV}$, foliate, fungiform papillae & Yee et al., 2011 \\
\hline Glut10 (S/c2A10) & glucose, galactose (Dawson et al., 2001) & Macaque & $\mathrm{CV}$, fungiform & Hevezi et al., 2009 \\
\hline Glut13 (Slc2A13) & glucose, IP3 (Zhao and Keating, 2007) & Macaque & $\mathrm{CV}$, fungiform & Hevezi et al., 2009 \\
\hline SGLT1 (SIC5) & $\begin{array}{l}\text { glucose, galactose (Sabino-Silva et al., 2010; Wright et al., } \\
\text { 2011) }\end{array}$ & Mouse & CV, foliate, fungiform & Yee et al., 2011 \\
\hline
\end{tabular}

Expression was detected by PCR (Merigo et al., 2011; Yee et al., 2011), immunohistochemistry (Merigo et al., 2011; Yee et al., 2011), or an affymetrix genome wide array (Hevezi et al., 2009). CV, circumvallate papillae. 


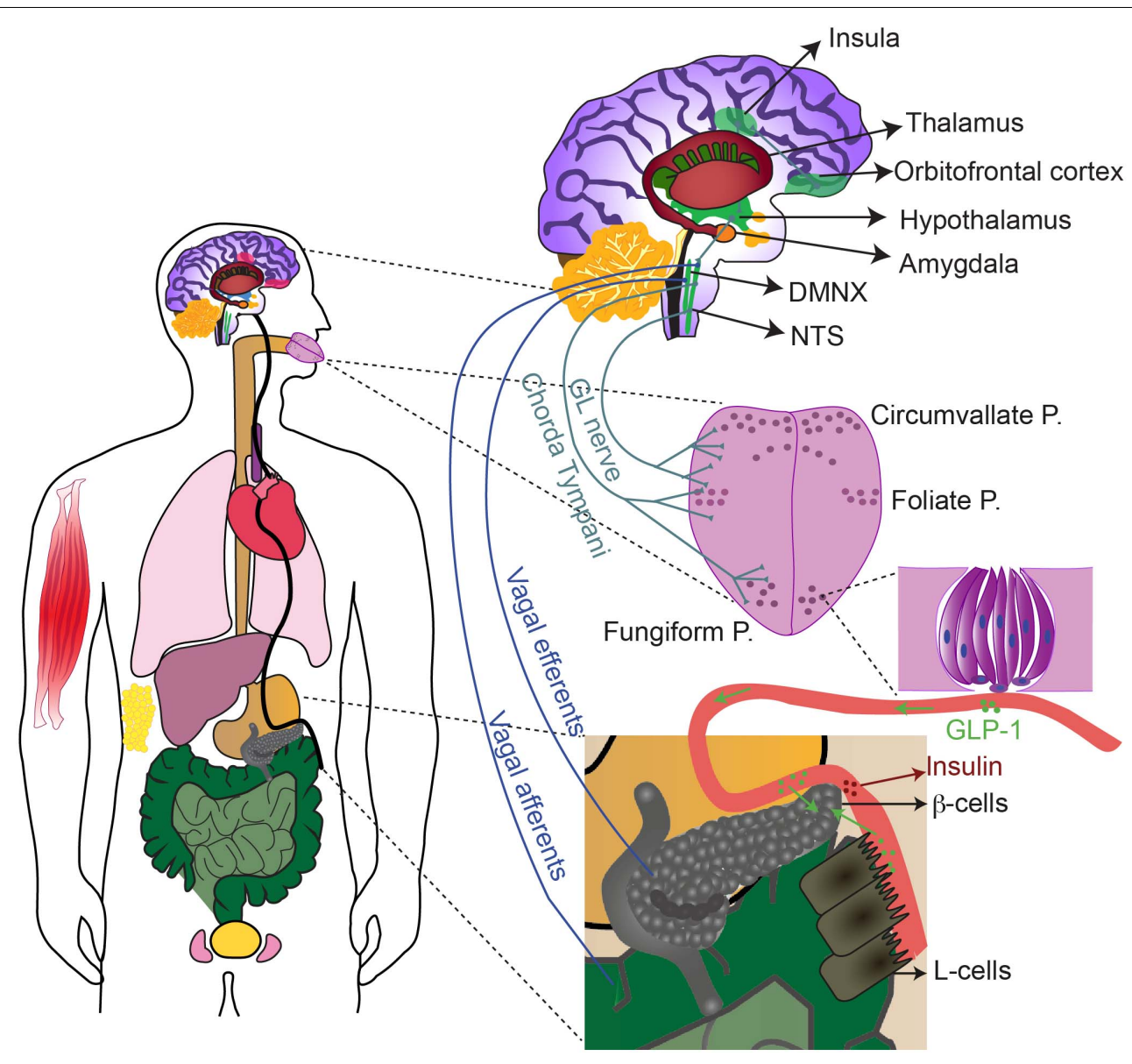

FIGURE 2 | The sweet taste receptor contributes to gustation and extraoral sugar-sensing. T1R2/T1R3, and possibly T1R3 homomers, are expressed with their downstream signaling molecules in multiple extraoral tissues (in color), including: oesophagus, stomach, liver, pancreas, intestine, bladder, testis, skeletal muscle, respiratory tract and adipose tissue. Activation of sweet-sensitive taste bud cells leads to purinergic stimulation of the chorda tympani and the glossopharyngeal (GL) nerves that send information, upon relay in the NTS and the thalamus, up to the insula. The insula communicates with several other brain regions (some are depicted) to regulate reward, motivation and energy homeostasis. Taste bud cells release also GLP-1 that can activate the afferent fibers as well. Sweet stimulation of taste bud cells thereby generates CPIR, possibly via NTS-DMNX communication and consequent activation of efferent vagal fibers. GLP-1 released by taste bud cells in the circulation, may also reach the pancreas, the intestine and the brain, exerting there paracrine effects.

TRMP5 activation and ATP release, or uses a completely different intracellular mechanism and neurotransmitter. In further support of the SGLT1 hypothesis, all sweet-responsive afferent fibers in T1R3-knockout mice were phlorizin sensitive and could be activated by the non-metabolizable sugar $\alpha \mathrm{MDG}$. In addition, $\mathrm{NaCl}$ increased licking of glucose solution in T1R3knockout animals, an effect blocked by phlorizin (Yasumatsu et al., 2020), providing evidence that the SGLT1-based pathway mediates sugar attraction. Theoretically, also disaccharides could be detected via the alternative pathway. Indeed, mouse taste cells express a group of disaccharidases, called "brush border" enzymes, that hydrolyze the disaccharides to monosaccharides, which in turn can enter the taste cells via the transporters (Merigo et al., 2009; Sukumaran et al., 2016). Additionally, livecell imaging in taste bud cells using a FRET-based glucose sensor (Deuschle et al., 2005) or (NAD(P)H,FAD) fluorescent imaging, may help to understand the contribution of SGLT1 and GLUTs to sweet responses. To unravel whether the alternative pathway also generates $\mathrm{Ca}^{2+}$ events to transduce gustatory responses, live $\mathrm{Ca}^{2+}$ imaging should be performed in taste bud cells of T1R3-knockout mice.

\section{Neurotransmitter and Physiological Role of the Alternative Pathway}

The alternative pathway may use not only a distinct intracellular signaling, but also a different neurotransmitter. A likely candidate for signal transmission from taste bud cells to gustatory nerves is glucagon-like peptide-1 (GLP-1) (Figures 1, 2). Indeed, GLP1 and its synthetizing enzyme convertase, were detected in a subset of type II and type III cells in mouse circumvallate papillae (Feng et al., 2008; Shin et al., 2010; Kokrashvili et al., 2014) (for review von Molitor et al., 2020c), while the related receptor (GLP-1R) was found in intragemmal nerve fibers (Shin et al., 2008; Takai et al., 2015). GLP-1 released by taste bud cells is selectively sweet- and lipid-dependent and it potentiates sweet 
taste mediated attraction (Martin et al., 2009; Martin et al., 2012). Besides this, taste bud cells may contribute to systemic GLP1, releasing it in the blood stream (Figure 2). In the body, GLP-1 is mainly released from enteroendocrine L-cells upon glucose uptake, via a mechanism involving SGLT1-mediated depolarization and activation of voltage-dependent calcium channels (VDCCs) (Best et al., 2010; Brubaker, 2017). Generally, GLP-1 controls fasting plasma glucagon, influences motoric mechanisms of gastric emptying, inhibits short-term food intake and potentiates pancreatic insulin release (Meier and Nauck, 2005; Schirra and Göke, 2005). In particular, GLP-1 induces the "cephalic phase insulin release" (CPIR). This is an innate response to sweet food ingestion that occurs prior its absorption, through which pancreatic insulin release occurs before blood glucose level rises (Louis-Sylvestre, 1976; Just et al., 2008). CPIR is important to prepare the body for ingestion, digestion, and storage of carbohydrate (Ahrén and Holst, 2001; Smeets et al., 2010). In healthy humans and rodents, CPIR is induced by oral exposure to sweet substances, but not to umami, salty or bitter compounds (Tonosaki et al., 2007; Just et al., 2008; Dušková et al., 2013). However, further studies are required to reveal the mechanism of GLP-1 release from sweet-sensitive taste bud cells and how this may induce CPIR (for review von Molitor et al., 2020c). Nonetheless, the alternative sweet-sensitive pathway could be a new interesting drug target (Laffitte et al., 2014; ZhuGe et al., 2020). If the idea holds true that taste bud cells mediate CPIR via oral secretion of GLP-1 (Chambers et al., 2017; Svendsen et al., 2018), controlling GLP-1 signaling in the tongue may help to control glycemia or even to treat diabetes (von Molitor et al., 2020c).

\section{CALORIC SUGARS AND NON-CALORIC SWEETENERS MAY UTILIZE DISTINCT PATHWAYS}

Before the discovery of the sweet taste receptor, taste bud cells responses to caloric and non-caloric sweeteners were proposed to be mediated by two different pathways. In rat taste buds, caloric sugars were shown to augment cAMP concentrations, while noncaloric sweeteners mainly raised intracellular IP3 concentration (Striem et al., 1991; Bernhardt et al., 1996). Moreover, with $\mathrm{Ca}^{2+}$ imaging experiments, it was shown that extracellular $\mathrm{Ca}^{2+}$ is required only for nutritive sugar-mediated responses (Bernhardt et al., 1996). Thus, the response to sugars seems to involve the cAMP/PKA pathway and to depend on $\mathrm{Ca}^{2+}$ influx, while non-caloric sweeteners probably induce IP3-mediated $\mathrm{Ca}^{2+}$ release from the stores (Bernhardt et al., 1996). However, it remains elusive, whether such a strict separation holds true, since saccharin was reported to activate both pathways: at low concentrations the cAMP/PKA-signaling, and at higher concentrations the IP3-pathway (Nakashima and Ninomiya, 1999). Presumably, saccharin can switch its activity from sweet to bitter agonist in a concentration-dependent manner (Kuhn, 2004; Galindo-Cuspinera, 2006; Behrens, 2017). Since mice deficient for PLCß2 (Zhang et al., 2003; Dotson et al., 2005) and TRPM5 (Zhang et al., 2003; Talavera et al., 2005; Damak et al., 2006) were shown to be insensitive to non-caloric sweeteners and to have largely reduced responses to natural sugars, PLC $\beta 2$ and TRPM5 may be crucial signaling molecules for perception of both caloric and non-caloric sweet tastants (for review von Molitor et al., 2020c). Furthermore, in rat taste buds the very same cells responded to sucrose and artifical sweeteners (Bernhardt et al., 1996; Lindemann, 1996). This can be interpreted as either both types of sweet stimuli activate the same pathway, or that two different pathways coexist in the same cell and interact. For example, GPCRs can mediate different signaling pathways via either, the $\alpha$ or $\beta \gamma$ subunit (Zhu et al., 1994; Zhu and Birnbaumer, 1996). In support of the two-pathways hypothesis, non-caloric sweeteners mediated responses differ from those elicited by natural sugars as they have a higher potency, a delayed on- and off-set, and a lower sweetness intensity (DuBois et al., 1991; DuBois, 2016; Wee et al., 2018). Therefore, they are ranked less sweet than sugars by humans (Antenucci and Hayes, 2015) and mice (Smith and Sclafani, 2002). Stimulation of taste buds with sugars and non-caloric sweeteners also evokes different physiological responses. Natural sugars were able to induce CPIR in humans, as described in most studies (Goldfine et al., 1969; Berthoud et al., 1980; Yamazaki and Sakaguchi, 1986; Tonosaki et al., 2007; Just et al., 2008; Shinozaki et al., 2008; Dušková et al., 2013; Dhillon et al., 2017), but for non-caloric sweeteners this is still controversial (reviewed Han et al., 2019; von Molitor et al., 2020c). Along the same line, there is clear evidence that GLP-1 is released by taste bud cells upon nutritive sugar consumption, but a corresponding efficacy of non-caloric sweeteners is debated (for review Renwick and Molinary, 2010; von Molitor et al., 2020c). Furthermore, upon oral perception, both caloric sugars and non-caloric sweeteners activated the gustatory cortex, but their responses differed in terms of intensity and activated regions (Frank et al., 2008; Chambers et al., 2009). Finally, while natural sugars activated brain reward areas, such as the dopaminergic midbrain area (Frank et al., 2008) and the striatum (Chambers et al., 2009), non-caloric sweeteners failed to do so (for review Han et al., 2019). Considering the broad consumption of non-caloric sweeteners, it is crucial to find an answer to these many open questions to better interpretate and predict their physiological effect.

\section{$\mathrm{Ca}^{2+}$ PATHWAYS IN TASTE RECEPTOR CELLS}

Sweet taste responses rely on intracellular $\mathrm{Ca}^{2+}$ signals, that are translated into afferent-fiber activity in order to send the information to upper brain centers. In this context, type II cells released $\mathrm{Ca}^{2+}$ from the stores via PLC/IP3-mediated signaling upon saccharin stimulation (Bernhardt et al., 1996; Rebello et al., 2013). Consistent with this observation, neither VDCCs gene expression nor depolarization-induced $\mathrm{Ca}^{2+}$ signals were observed in type II cells (Clapp et al., 2006; DeFazio et al., 2006). However, others reported voltage-dependent $\mathrm{Ca}^{2+}$ influx in a subpopulation of bitter-responding cells, that may feature both type II and type III cells (Hacker and Medler, 2008) (for review Medler, 2015). Consistenly, the presence of "broadly responsive" 
taste bud cells has been recently reported, that are positive for the type III cell marker SNAP25, and respond to KCl-mediated depolarization with $\mathrm{Ca}^{2+}$ influx. Further, they responded to bitter, umami and/or sweet stimuli with $\mathrm{Ca}^{2+}$ signals mediated, in this case, by a different PLC: the PLC $\beta 3$. Thus, these "broadly responsive" cells feature both voltage-dependent $\mathrm{Ca}^{2+}$ influx and intracellular $\mathrm{Ca}^{2+}$ release, even if it remained elusive, wether they express VDCCs, T2R and T1R. In all papillae types, such cells represented about $20-30 \%$ of all taste bud cells and about $50 \%$ of type III cells. Furthermore, since PLC $\beta 3$-knockout mice have a reduced licking behavior to bitter, sweet and umami stimuli, this cell population crucially contributes to taste perception (Banik et al., 2018; Dutta Banik et al., 2020).

Further potential $\mathrm{Ca}^{2+}$ mobilization routes include: cyclic nucleotide gated (CNG) channels, store-operated $\mathrm{Ca}^{2+}$ channels (SOCs), vanilloid-receptor-1 (TRPV1), and Calcium Sensing Receptor (CaSR) (Figure 1 and Table 5).

First, CNG channels are pivotal in decoding visual and olfactory sensations (Bradley et al., 2005). In frog taste bud cells, electrophysiological experiments have shown the presence of a CNG conductance that was inhibited by cAMP/cGMP. This argued for a sequence of events, whereby tastant-induced transducin activation would trigger PDE, leading to cyclic nucleotide degradation, CNG channel activation, depolarization and $\mathrm{Ca}^{2+}$ influx (Kolesnikov and Margolskee, 1995). In 1997, Misaka et al. cloned another CNG from rat tongue epithelial tissue that was present specifically in taste buds of circumvallate papillae at the pore side, whose expression disappeared upon glossopharyngeal nerve denervation. In contrast to the channel described by Kolesnikov and Margolskee, this channel was shown, in a recombinant system, to be activated by cGMP and cAMP (Misaka et al., 1997). However, it remained elusive whether it is able to conduct $\mathrm{Ca}^{2+}$, if it is functional in the native tissue and if it is linked to the sweet taste transduction pathway.

Second, SOCs may provide another way for $\mathrm{Ca}^{2+}$ entry into taste bud cells. In general, they are responsible for capacitive $\mathrm{Ca}^{2+}$ entry upon depletion of the store. In mouse taste bud cells, SOCs are composed of the proteins orai- 1 and orai-3, which are under the control of an endoplasmatic- $\mathrm{Ca}^{2+}$ depletion sensor, i.e., stromal interaction molecule-1 (STIM-1). STIM-1 was shown to mediate the perception of fatty acids by the induction of $\mathrm{Ca}^{2+}$ signals (Dramane et al., 2012; Abdoul-Azize et al., 2014). Orai-1 and orai-3 are expressed in CD36 positive cells (Dramane et al., 2012), with CD36 and GPR120 being considered as receptors for fatty acids. In mouse, both receptors are expressed in some type II and type III cells (Matsumura et al., 2009; Gilbertson and Khan, 2014). They mediate $\mathrm{Ca}^{2+}$ signals and the release of serotonin and GLP-1 (Ozdener et al., 2014). Since longchain fatty acids reinforce attraction to sugars (Martin et al., 2012), there might be a cross talk between signaling pathways triggered by fatty acids and sweet tastants. Indeed, TRPM5 may be a key signaling component in both pathways, since TRPM5knockout mice had not only a reduced sweet taste sensitivity, but also an abolished fat preference (Sclafani et al., 2007). Interestingly, store-operated $\mathrm{Ca}^{2+}$ entry is involved in responses to prolonged bitter stimulation, meaning that not only $\mathrm{Ca}^{2+}$ release but also $\mathrm{Ca}^{2+}$ influx may be important for transduction
TABLE 5 | Possible $\mathrm{Ca}^{2+}$ signaling pathways in type II taste bud cells.

\begin{tabular}{|c|c|c|c|}
\hline Molecule & Activation & Effect & Source \\
\hline VDCC & depolarization & $\mathrm{Ca}^{2+}$ influx & $\begin{array}{l}\text { Béhé et al., } \\
\text { 1990; Medler } \\
\text { et al., 2003; } \\
\text { Hacker and } \\
\text { Medler, } 2008\end{array}$ \\
\hline ORAI/STIM & $\begin{array}{l}\mathrm{Ca}^{2+} \text { release } \\
\text { from the store }\end{array}$ & $\mathrm{Ca}^{2+}$ influx & $\begin{array}{l}\text { Ogura et al., } \\
\text { 2002; } \\
\text { Matsumura } \\
\text { et al., 2009; } \\
\text { Gilbertson and } \\
\text { Khan, 2014; } \\
\text { Ozdener et al., } \\
2014\end{array}$ \\
\hline TRMP5/TRPM4 & $\begin{array}{l}\text { depolarization } \\
\text { and } \mathrm{Ca}^{2+}\end{array}$ & $\begin{array}{l}\mathrm{Na}^{+} \text {influx and } \\
\text { depolarization }\end{array}$ & $\begin{array}{l}\text { Pérez et al., } \\
\text { 2002; Prawitt } \\
\text { et al., 2003; } \\
\text { Talavera et al., } \\
\text { 2005; Kaske } \\
\text { et al., } 2007\end{array}$ \\
\hline CNG & cAMP/cGMP & $\begin{array}{l}\mathrm{Na}^{+} \text {influx and } \\
\text { depolarization }\end{array}$ & $\begin{array}{l}\text { Kolesnikov and } \\
\text { Margolskee, } \\
\text { 1995; Misaka } \\
\text { et al., } 1997\end{array}$ \\
\hline $\begin{array}{l}\text { Ryanodine } \\
\text { Receptor }\end{array}$ & $\begin{array}{l}\mathrm{Ca}^{2+}, \text { L-type } \\
\text { VDCC }\end{array}$ & $\begin{array}{l}\mathrm{Ca}^{2+} \text { release } \\
\text { from the store }\end{array}$ & $\begin{array}{l}\text { Rebello and } \\
\text { Medler, 2010; } \\
\text { Rebello et al., } \\
2013\end{array}$ \\
\hline IP3R & IP3 & $\begin{array}{l}\mathrm{Ca}^{2+} \text { release } \\
\text { from the store }\end{array}$ & $\begin{array}{l}\text { Clapp et al., } \\
2001 \text {; Hacker } \\
\text { and Medler, } \\
2008\end{array}$ \\
\hline TRPV1 & $\begin{array}{l}\text { capsaicine, } \\
\text { temperature, } \\
\mathrm{H}^{+}\end{array}$ & $\begin{array}{l}\mathrm{Ca}^{2+}, \mathrm{Na}^{+} \\
\mathrm{K}^{+}, \mathrm{Mg}^{2+} \text { influx }\end{array}$ & $\begin{array}{l}\text { Lyall et al., } \\
\text { 2004; Hacker } \\
\text { and Medler, } \\
\text { 2008; } \\
\text { Laskowski and } \\
\text { Medler, } 2009\end{array}$ \\
\hline CaSR & glutation, $\mathrm{Ca}^{2+}$ & $\begin{array}{l}\mathrm{Ca}^{2+} \text { release } \\
\text { from the store }\end{array}$ & $\begin{array}{l}\text { Maruyama } \\
\text { et al., 2012; } \\
\text { Medina et al., } \\
2016\end{array}$ \\
\hline
\end{tabular}

Expression and functionality were assessed with RT-PCR (Prawitt et al., 2003; Hacker and Medler, 2008; Laskowski and Medler, 2009; Matsumura et al., 2009; Rebello and Medler, 2010; Maruyama et al., 2012) immunohistochemistry (Misaka et al., 1997; Clapp et al., 2001; Medler et al., 2003; Kaske et al., 2007; Hacker and Medler, 2008; Matsumura et al., 2009; Rebello and Medler, 2010; Maruyama et al., 2012; Rebello et al., 2013; Medina et al., 2016), in situ hybridization (Pérez et al., 2002), live-microscopy imaging (Ogura et al., 2002; Hacker and Medler, 2008; Laskowski and Medler, 2009; Rebello and Medler, 2010; Maruyama et al., 2012; Rebello et al., 2013; Ozdener et al., 2014; Medina et al., 2016), and electrophysiology (Béhé et al., 1990; Kolesnikov and Margolskee, 1995; Misaka et al., 1997; Medler et al., 2003; Prawitt et al., 2003; Lyall et al., 2004; Talavera et al., 2005).

(Ogura et al., 2002). Probably, this mechanism has been often underestimated, since the majority of electrophysiological and functional imaging experiments used only brief taste stimuli applications. Still, it is not known if prolonged sweet stimuli also require store-operated $\mathrm{Ca}^{2+}$ influx.

Third, the vanilloid-receptor-1 (TRPV1) is a non-selective cation channel permeable to $\mathrm{Na}^{+}, \mathrm{Ca}^{2+}, \mathrm{K}^{+}$and $\mathrm{NH}_{4}{ }^{+}$which 
TABLE 6 | Gastro-intestinal expression of sweet taste signaling molecules.

\begin{tabular}{|c|c|c|c|c|c|c|c|c|c|c|}
\hline Organ & $T 1 R 2$ & $T 1 R 3$ & $T 2 R$ & $G \alpha_{\text {gust }}$ & $P L C \beta 2$ & TRPM5 & GLUT/SGLT & $K_{\text {ATP }}$ & Species & Source \\
\hline $\begin{array}{l}\text { Oeso- } \\
\text { phagus }\end{array}$ & & $\checkmark$ & & $\begin{array}{c}\checkmark \\
\text { low }\end{array}$ & & $\begin{array}{c}\checkmark \\
\text { low }\end{array}$ & & & Human & $\begin{array}{l}\text { Young et al., } \\
2009\end{array}$ \\
\hline Stomach & $\checkmark$ & $\checkmark$ & $\checkmark$ & $\checkmark$ & $\checkmark$ & $\checkmark$ & $\checkmark$ & $\checkmark$ & Mouse & $\begin{array}{l}\text { Hass et al., } \\
\text { 2007; Kaske } \\
\text { et al., 2007; } \\
\text { Bezençon } \\
\text { et al., 2008; } \\
\text { Hass et al., } \\
\text { 2010; Janssen } \\
\text { et al., 2011; } \\
\text { Widmayer } \\
\text { et al., 2011; } \\
\text { Sakata et al., } \\
2012\end{array}$ \\
\hline \multirow[t]{4}{*}{ Intestine } & $\checkmark$ & $\checkmark$ & $\checkmark$ & & $\checkmark$ & $\checkmark$ & & & & \\
\hline & & & & & low & & & & Human & $\begin{array}{l}\text { Bezençon } \\
\text { et al., 2007; } \\
\text { Jang et al., } \\
\text { 2007; Young } \\
\text { et al., } 2009\end{array}$ \\
\hline & $\checkmark$ & $\checkmark$ & $\checkmark$ & $\checkmark$ & & & $\checkmark$ & & Mouse & $\begin{array}{l}\text { Dyer et al., } \\
2005 ; \\
\text { Margolskee } \\
\text { et al., 2007; } \\
\text { Janssen et al., } \\
2011\end{array}$ \\
\hline & & & & & & & $\checkmark$ & $\checkmark$ & Rat & $\begin{array}{l}\text { Kuhre et al., } \\
2015\end{array}$ \\
\hline \multirow[t]{5}{*}{ Colon } & & $\checkmark$ & $\checkmark$ & $\checkmark$ & & & & & Human & $\begin{array}{l}\text { Taniguchi, } \\
\text { 2004; } \\
\text { Rozengurt } \\
\text { et al., } 2006\end{array}$ \\
\hline & $\checkmark$ & $\checkmark$ & & $\checkmark$ & & & & & & \\
\hline & & & & low & & & & & Mouse & $\begin{array}{l}\text { Bezençon } \\
\text { et al., 2008; } \\
\text { Reimann et al., } \\
2008\end{array}$ \\
\hline & & & & & & & $\checkmark$ & & & \\
\hline & & & & & & & low & & Rat & Jie et al., 2015 \\
\hline \multirow[t]{3}{*}{ Pancreas } & & $\checkmark$ & & & & $\checkmark$ & $\checkmark$ & $\checkmark$ & Human & $\begin{array}{l}\text { Prawitt et al., } \\
\text { 2003; } \\
\text { Taniguchi, } 2004\end{array}$ \\
\hline & $\checkmark$ & $\checkmark$ & & $\checkmark$ & & $\checkmark$ & $\checkmark$ & $\checkmark$ & Mouse & $\begin{array}{l}\text { Prawitt et al., } \\
\text { 2003; } \\
\text { Nakagawa } \\
\text { et al., 2009; } \\
\text { Colsoul et al., } \\
\text { 2010; } \\
\text { Nakagawa } \\
\text { et al., } 2014\end{array}$ \\
\hline & & & & & & & $\checkmark$ & $\checkmark$ & Rat & $\begin{array}{l}\text { Cook and } \\
\text { Hales, 1984; } \\
\text { Inagaki et al., } \\
\text { 1995; Vos } \\
\text { et al., } 1995\end{array}$ \\
\hline
\end{tabular}

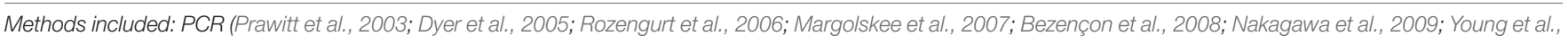

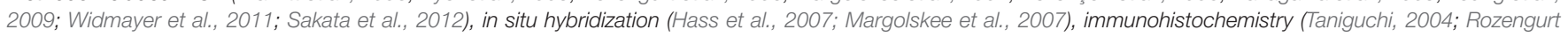

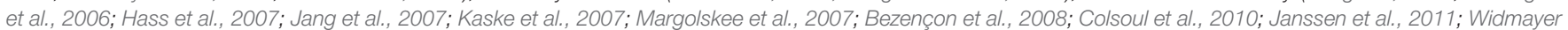
et al., 2011), biochemical measurement (Kuhre et al., 2015), or transcriptome analysis (Jie et al., 2015). 
is modulated by diverse stimuli such as vanilline, temperature, voltage and capsaicine. It was proposed to be responsible for salt detection, since it mediates amiloride-insensitive responses of the chorda tympani nerve not only to $\mathrm{Na}^{+}$, but also to $\mathrm{Ca}^{2+}, \mathrm{K}^{+}$and $\mathrm{NH}_{4}{ }^{+}$(Lyall et al., 2004). It is responsible for constitutive $\mathrm{Ca}^{2+}$ entry, which is then regulated by mitochondrial $\mathrm{Ca}^{2+}$ buffering and membrane $\mathrm{Ca}^{2+}$ extrusion via the $\mathrm{Na}^{+}-\mathrm{Ca}^{2+}$ exchanger (NCX) (Hacker and Medler, 2008; Laskowski and Medler, 2009). The concerted action of these players may contribute to the regulation of intracellular $\mathrm{Ca}^{2+}$ homeostasis in taste bud cells. In fact, both pharmacological alteration of the mitochondrial potential (Hacker and Medler, 2008) and blocking of NCX, induced $\mathrm{Ca}^{2+}$ signals in taste bud cells (Laskowski and Medler, 2009). Also, mitochondria were shown to differentially contribute to $\mathrm{Ca}^{2+}$ buffering in type II and type III cells (Hacker and Medler, 2008; Medler, 2015), and metabolic stimuli may affect intracellular $\mathrm{Ca}^{2+}$ homeostasis by interfering with mitochondrial activity: in type II cells, changes in mitochondrial potential induced by glucose metabolism may decrease mitochondrial $\mathrm{Ca}^{2+}$ buffering and affect intracellular $\mathrm{Ca}^{2+}$ transients (Hacker and Medler, 2008; Medler, 2015).

Fourth, an additional taste, called kokumi, makes use of the CaSR to induce specialized $\mathrm{Ca}^{2+}$ signals (Maruyama et al., 2012; Medina et al., 2016). CaSR is a typical GPCR which plays a central role in mammalian $\mathrm{Ca}^{2+}$ homeostasis (Chattopadhyay et al., 1997). It is present in both type II and type III cells, but it is not coexpressed with T1R3 (Bystrova et al., 2010; Maruyama et al., 2012). In rodents, most CaSR-positive cells were found in circumvallate and foliate papillae (San Gabriel et al., 2009). CaSR is activated by glutathione and cations such as $\mathrm{Ca}^{2+}, \mathrm{Mg}^{2+}$ and $\mathrm{Gd}^{3+}$. Although these CaSR agonists alone have no flavor, they enhanced the intensity of sweet or umami sensation. When recombinant CaSR was expressed in HEK cells, glucose and sucrose were able to elicit $\mathrm{Ca}^{2+}$ transients in the presence of extracellular $\mathrm{Ca}^{2+}$, suggesting that CaSR can be allosterically modulated by sugars to mobilize $\mathrm{Ca}^{2+}$ via a downstream pathway (Medina et al., 2016). Indeed, in mouse taste cells, kokumi substances induced intracellular $\mathrm{Ca}^{2+}$ release via PLC (Maruyama et al., 2012). CaSR can also be activated by bitter compounds (Rogachevskaja et al., 2011) and may, therefore, exert an ubiquitous and still largely unknown modulatory effect on several taste modalities.

\section{PRESENCE AND ROLE OF SWEET TASTE RECEPTOR IN EXTRAORAL TISSUES}

Apparently, T1R2/T1R3 is not only responsible for sweet taste detection in the oral cavity, since it is also expressed in several extra oral tissues (Figure 2), together with its downstream signaling molecules (Table $\mathbf{6}$ and Figure 2) (for review Yamamoto and Ishimaru, 2013; Laffitte et al., 2014). Most of these tissues are involved in carbohydrate metabolism and there, the sweet taste receptor is involved in nutrient sensing, monitoring changes in energy storage and triggering metabolic and behavioral responses to maintain the energy balance (Lee and Owyang, 2017). Thus, the wide expression of the sweet taste receptor highlights potential health risks that sweeteners pose, due to their multiple targets in the body (Laffitte et al., 2014). The following paragraphs briefly introduce the main findings on extraoral expression of sweet taste receptors and the knowledge on their function there.

\section{Sweet Taste Receptors in the Gastrointestinal Tract}

In the esophagus, mainly T1R3-homodimers are present (Young et al., 2009), while in the mouse stomach, T1R3 is expressed at higher levels than T1R2, supporting the hypothesis that homomeric and dimeric receptors may be both present (Hass et al., 2010). Gustducin expression in rat stomach, duodenum, and the pancreatic duct was already known in 1996 (Höfer et al., 1996). Later, Hass et al. identified a cluster of gustducin, PLC $\beta 2$ and TRPM5 expressing cells in the mouse stomach. Even if colocalization studies were not possible, they noticed that gustducin and TRPM5 positive cells were scattered, whereas PLC 32 positive cells were restricted to a basolateral subcompartment (Hass et al., 2007). PLC $\beta 2$ positive cells further expressed cytokeratin 18, a marker for brush cells (Hass et al., 2007). In a follow up study, they showed also T1R3 expression in this region (Hass et al., 2010). Thus, these brush cell clusters may have chemosensory function and support the gastric compartment to sense nutrients. This may not only initiate the appropriate gastric processes for digestion and regulate gastric emptying (Rozengurt, 2006; Kendig et al., 2014), but may also be relevant to transmit information to the hypothalamic nuclei governing food intake (Hass et al., 2010). Accordingly, gustducin and T1R3 are coexpressed with the hunger hormone ghrelin (Hass et al., 2010; Janssen et al., 2011). Concerning the sweet taste receptor independent pathway, mRNAs encoding GLUT1,4,5 and components of the $\mathrm{K}_{A T P}$ channel (Kir6.2 and SUR1), were also detected in the pool of gastric mucosal cells secreting ghrelin. However, activators or inhibitors of the $\mathrm{K}_{A T P}$ channel did not change ghrelin release, as shown with mouse ghrelinoma cells kept at low density (Sakata et al., 2012). Hence, both the canonical and the alternative pathway may play a role in a ghrelin releasing cells of the stomach.

RT-PCR results have shown that humans and mice similarly express T1R2, T1R3, gustducin, PLCB2 and TRMP5 in gastrointestinal tissues, with the exception of T1R2 that was not detected in the stomach (Bezençon et al., 2007). In rodent intestinal cell lines, T1R2/T1R3 is coexpressed with $\alpha$-gustducin (Dyer et al., 2005; Margolskee et al., 2007). Additionally, in humans, the sweet taste receptor is highly expressed in the jejunum and duodenum and to a lesser content in the ileum (Dyer et al., 2005; Young et al., 2009). Moreover, gustducin was detected in more than $90 \%$ of human L-cells, in less than $50 \%$ of K-cells, and in other cell types in the duodenum (Jang et al., 2007). Gustducin expression was most prominent in the mid-jejunum (Young et al., 2009), the place where carbohydrateinduced reflexes are likely to be initiated (Lin et al., 1989). Besides this, the expression of PLCB2 (Young et al., 2009) and TRPM5 (Prawitt et al., 2003; Young et al., 2009) has been demonstrated in gastro-intestinal cells, where they might be involved in sugar 
sensing via canonical sweet signaling (Table 6; Dyer et al., 2005; Bezençon et al., 2007). While the release of ghrelin by T1R3expressing brush and endocrine cells (Hass et al., 2010) seemed to be sweet taste receptor and gustducin independent in mice (Steensels et al., 2016), the canonical pathway may mediate the release of GLP-1. Indeed, intestinal cells, expressing T1R2 and T1R3, released GLP-1 (Dyer et al., 2005; Jang et al., 2007), which was reduced in T1R3-knockout mice and upon sweet taste receptor inhibition (Jang et al., 2007). Furthermore, T1R3 and gustducin were shown to regulate the expression of SGLT1 in enterocytes, since sugars and non-caloric sweeteners stimulated SGLT1 expression and glucose absorptive capacity in wild-type mice, but not in T1R3- or gustducin-knockout mice (Margolskee et al., 2007). More recently, glucose intake via GLUT2 was found to induce the release of GLP-1 in rat intestine via glucose metabolism and ATP-mediated closure of $\mathrm{K}_{\text {ATP }}$ (Kuhre et al., 2015). Thus, as in the taste buds, both sweet taste receptor dependent and independent pathways may coexist.

The expression of T1R3 and gustducin has been shown also in human enteroendocrine L-cells of the colon (Rozengurt et al., 2006). Curiously, in mouse colon cells, gustducin is coexpressed with TRPM5, but not with PLC 32 nor T1R3 (Bezençon et al., 2008). Further, SGLT1 and $K_{A T P}$ expression in rat colon cells is low (Reimann et al., 2008). As gustducin expression was found in L-cells, which secrete GLP-1 and peptide tyrosine tyrosine (PYY), sweet taste receptors there may be involved in energy homeostasis (Rozengurt et al., 2006; Rozengurt, 2006). Additionally, it was proposed that T1R3/T1R2, along with T2R, may play a role in the peristaltic reflex (Rozengurt, 2006; Kendig et al., 2014).

\section{Sweet Taste Receptors in the Pancreas}

Another key player in glucose homeostasis is the pancreas, where increased blood glucose levels are sensed via GLUT2. Upon glucose transport into $\beta$-cells, oxidative phosphorylation occurs which increases intracellular ATP that in turn inactivates $\mathrm{K}^{+}$channels to mediate cell depolarization. This mechanism links glycolysis to hormonal release, since subsequent VDCCsmediated $\mathrm{Ca}^{2+}$ influx triggers insulin secretion (Yamamoto and Ishimaru, 2013; Laffitte et al., 2014). Additionally, the pancreas senses sweet compounds via T1R3 and T1R2, which are both coexpressed with gustducin, as shown in MIN6 cells and mouse $\beta$-cells (Nakagawa et al., 2009; Medina et al., 2014). However, low mRNA levels of T1R2 were detected, suggesting that here T1R3-homodimers may be present and contribute to sweet taste receptor function (Young et al., 2009; Medina et al., 2014). T1R3 activation was shown to increase ATP production by promoting mitochondrial metabolism (Nakagawa et al., 2014; Kojima et al., 2015). Stimulation of $\beta$-cells with fructose, sucralose or non-caloric sweeteners led to increased insulin blood levels (Nakagawa et al., 2009), an effect blocked by knocking out T1R3 or inhibiting it with gurmarin, suggesting T1R3 functionality in $\beta$-cells (Geraedts et al., 2012; Nakagawa et al., 2013; Medina et al., 2014). In addition, TRMP5-knockout mice showed diminished glucose-mediated insulin secretion (Colsoul et al., 2010). Thus, in the pancreas, the canonical sweet taste pathway may function in synergy with the GLUTmediated pathway.

\section{Sweet Taste Receptors in Other Tissues}

Sweet taste receptor expression has been additionally documented in multiple other tissues not directly involved in glucose homeostasis, such as respiratory tract (Lee and Cohen, 2014; Workman et al., 2015), liver (Taniguchi, 2004), testes (Gong et al., 2016), heart (Wauson et al., 2012), bladder (Elliott et al., 2011), skeletal muscle (Kokabu et al., 2017), and adipose tissue (Masubuchi et al., 2013; Figure 2). The role of sweet taste receptors in these tissues is reviewed elsewhere (Lee and Cohen, 2015).

Besides metabolic functions, taste receptors may play a role also in the innate immune response. In support of this, human solitary chemosensory cells (SCCs) expressed T2R and T1R receptors (Lee et al., 2014). SCCs are discrete, nonciliated cells of the nasal respiratory epithelium (Yamamoto and Ishimaru, 2013; Maina et al., 2018). As shown in rodents, they express gustducin (Finger et al., 2003) and TRPM5 (Lin et al., 2008). During infection of the upper airways, gramnegative bacteria release bitter noxious substances, called acylhomoserine lactones (AHLs), which are agonists of T2R38 (Lee et al., 2012). Accordingly, human neutrophils can identify AHLs via T2R38 (Maurer et al., 2015) and additional T2R members (Yan et al., 2017). T2R stimulation then leads to PLC $\beta 2$ activation and increased intracellular $\mathrm{Ca}^{2+}$ which spreads to neighboring ciliated cells via gap junctions to induce secretion of anti-microbial peptides for killing pathogenic microbes (Finger et al., 2003; Lee et al., 2014) (for review see Maina et al., 2018; Triantafillou et al., 2018). Stimulation of the sweet taste receptor, expressed in the same cells, led to inhibition of this defense pathway (Lee et al., 2014). However, when bacteria metabolize glucose, its concentration in the airway mucus decreases and this interrupts the tonic activation of T1R2/T1R3, boosting the immune response (Maina et al., 2018). Thus, the combination of sweet taste receptor antagonists with bitter receptor agonists could be a new potential pharmacological approach to treatment chronic rhinosinusitis or airway infections (reviewed in Workman et al., 2015; Maina et al., 2018).

The ubiquitous expression of sweet taste receptors indicates that sweet compounds and other allosteric binding partners of T1R2/T1R3 (Kojima and Nakagawa, 2011) and T1R3-homomeric receptors (Young et al., 2009; Medina et al., 2014) may induce potential health risks via inappropriate metabolic effects, such as: stimulating the release of gut or pancreatic hormones, altering glucose absorption, or modulating immune responses (Geraedts et al., 2012; Laffitte et al., 2014). The other way around, this may open new theraputical prospectives for the treatment of obesity related metabolic disfunctions (Laffitte et al., 2014; Workman et al., 2015; Maina et al., 2018).

\section{HOW SUGARS AFFECT THE BRAIN}

The ability to detect sugars is crucial in human nutrition as it orients food choice and energy intake. Sugars not only provide the energy necessary for metabolism, but also guide the behavior. Our preference for sugars is innate (Steiner et al., 2001), but affective responses to flavors are acquired based on experience 
(Araujo et al., 2020), allowing the organism to learn which food is rich in energy. Further, sugar preference mediates attraction and reward mechanisms (for review Gutierrez et al., 2020). Thus, both nutritional and sensory properties regulate food intake.

Sugar preference and intake are controlled at least on three levels: gustation, gut-brain axis and brain-glucose sensing. The brain can sense glucose either directly or indirectly via oro- and visceral-sensation. Sensory, hedonic and metabolic values are encoded by separate brain circuitries working in parallel (Araujo et al., 2012) (for review Han et al., 2019; Gutierrez et al., 2020). Notably, preference for sugars does not seem to depend on its caloric content (Wright et al., 2011; Zukerman et al., 2013) nor on sweet taste receptors (Araujo et al., 2008; Ren et al., 2010; Oliveira-Maia et al., 2012; Tan et al., 2020), and even if food palatability affects what we eat, it does not influence how much we eat (Araujo, 2016). Rather, post-oral mechanisms are critical in controlling sugar intake and establishing long-term preference (Araujo, 2011). Therefore, different factors and pathways appear to regulate our preference for sugars on the one hand, and the amount of sugar consumption on the other hand.

\section{Gustatory Representation}

Consciously, sweetness can be perceived only upon activation of the sweet taste receptor in the oral cavity. Therefore, type II cells communicate with afferent gustatory fibers; these send the information, via several relay stations, up to the cortex (Figure 2; Ohla et al., 2019). How the taste quality is conveyed to the brain, is still a matter of debate. Yet, it is widely accepted that taste bud cells are hardwired to a defined behavior, i.e., not the identity of the taste receptor but of the perceiving cells determine the behavioral response. For example, when an opiate (Zhao et al., 2003) or a bitter-taste receptor (Mueller et al., 2005) was expressed in type II sweet-sensitive cells of mice, these transgenic animals were attracted by tasteless synthetic opiates or by bitter tastants, respectively. Thus, it was thought that sweet-responding taste bud cells respond only to this taste modality, however this view has been recently challenged by the discovery of broadly responding taste cells (Banik et al., 2018; Dutta Banik et al., 2020).

Afferent neurons may respond either to only one (best stimulus) or to multiple qualities (broadly tuned), and their tuning may vary according the stimulus concentration (Barretto et al., 2015; Wu et al., 2015). The cell bodies of the afferent neurons are located either in the geniculate, petrosal or nodose ganglia, projecting to the rostral portion of the solitary tract nucleus (rNTS) (Corson and Erisir, 2013). In human, the rNTS secondary neurons send their axons directly to the parvocellular portion of the Vetroposteromedial nucleus of the thalamus (VPMpc), while in rodents they make a first relay in the parabrachial nucleus (Samuelsen et al., 2013). From the thalamus, the information is conveyed to the primary gustatory cortex, called insula (IC), that further projects to the orbitofrontal cortex (for review Small, 2012; Ohla et al., 2019; Figure 2).

Electrophysiological and live-imaging experiments in rodents have shown that along the neural axis, both specialized and generalized neurons encode the sweet taste (Spector and Travers, 2005; Ohla et al., 2019). Moving toward higher brain centers, a growing percentage of neurons responds to multiple stimuli (broadly tuned). Here, combinatorial and temporal coding are crucial for taste decoding, thus the neuronal ensembles and their firing frequency pattern decode important gustatory information (Spector and Travers, 2005; Stapleton et al., 2007; Ohla et al., 2019). Accordingly, sweet taste intensity is decoded by neuronal firing frequency in the insular cortex and in the orbitofrontal cortex (Fonseca et al., 2018). In human, a gustatopic map has been recognized in the insula, where discrete regions were activated by oral exposure to a defined taste modality, and even the concentration intensity was represented by a spatial gradient (Prinster et al., 2017; Canna et al., 2019; Chikazoe et al., 2019; Porcu et al., 2020). On the contrary, other data support rather a distributed pattern of activity (Ohla et al., 2019; Porcu et al., 2020). Accordingly, no insular region revealed a consistent preference for a specific taste quality (Avery et al., 2020) and taste representation was not only highly variable across subjects (Schoenfeld et al., 2004; Avery et al., 2020), but also within subjects on different days (Avery et al., 2020). It is controversially discussed also for rodents whether the different taste modalities are encoded by topographically distinct cortical fields (Chen et al., 2011; Fletcher et al., 2017; for review Ohla et al., 2019). Optogenetic stimulation of the sweet responsive insular region induced increased licking of water in mice, suggesting that they perceived it as a sweet solution (Peng et al., 2015). Thus, the internal representation in the insula may underlie innate sweet preference. The insula not only encodes the chemical identity, but also the palatability of tastants (Araujo et al., 2006) and communicates with higher and lower-order neural relays, such as the striatum (Small et al., 2003; Oliveira-Maia et al., 2012) and the orbitofrontal cortex (Haase et al., 2008). Thus, as shown by electrophysiolgical recordings in mice, palatability is encoded by a widespread network including multiple brain regions (Parabrachial Nucleus, VPMpc, Basolateral Amygdala, Nucleus Accumbens Shell and lateral hypothalamic area) (for review Gutierrez et al., 2020). The coordinated action of these neural pathways motivates sugar intake. Furthermore, the insula preferentially interacts with the hypothalamus when the stimulus is nutritive (Rudenga et al., 2010). While it is still discussed whether the sweet taste itself can stimulate hunger (for review Low et al., 2014), sugars can induce attraction even in the absence of sweet taste receptor-mediated oral sensation, as shown with different ageusic transgenic mice (Nelson et al., 2001; Araujo et al., 2008; Sclafani et al., 2014). Oral sweet-sensing influences the initial food acceptance, but it does not determine the daily caloric intake (Glendinning et al., 2010; Ren et al., 2010). Other senses also influence sweet perception and hedonic value, via multisensory integration in the NST (Travers and Norgren, 1995), in the insula and in the orbitofrontal cortex (Rolls and Baylis, 1994) (for review Small, 2012). Sweet perception is additionally influenced by expectation (Veldhuizen et al., 2007), emotions (Noel and Dando, 2015), and metabolic state (Zhang et al., 2018).

\section{Gut-Brain Axis}

To feel pleasure and develop attraction to sugars, taste recognition needs to be integrated with energy-value sensing. Preference for a certain flavor develops only when its taste is 
paired to post-ingestive reward signals (for review Kim et al., 2018; Gutierrez et al., 2020). Accordingly, mice develop a preference for sugars over non-caloric sweeteners within $48 \mathrm{~h}$, when solutions, perceived equivalenty sweet, were provided (Tan et al., 2020). The mechanism involved is also responsible for sugar craving (Volkow et al., 2011). Sensing of the metabolic value occurs in the gastro-intestinal tract and/or the portal vein, both sending signals via vagal afferent fibers to the NTS and from here to upper brain centers. Specifically, in mice, proenkephalinepositive neurons of the caudal nucleus of the solitary tract (cNTS) were strongly activated by ingestion or intragastric application of sugars, but not of non-caloric sweeteners. This was mediated by vagal sensory neurons of the nodose ganglia receiving input from the duodenum and synapsing to cNTS excitatory neurons (Tan et al., 2020). Silencing these vagal afferents or the proenkephaline-positive neurons prevented the development of sugar preference, but left innate sweet attraction intact. Thus, innate sweet attraction and learned sugar preferences use different neural circuitries. Substrates of SGLT1, such as nonmetabolizable 3-OMG and galactose, were also able to activate vagal sensory neurons in the intestine. The lack of responses to non-caloric sweeteners, fructose and mannose further supported the involvement of SGLT1, since they are no substrates of SGLT1 (Tan et al., 2020). Consistently, in SGLT1-deficient mice, flavor conditioning to glucose was impaired, while natural preference was not affected (Sclafani et al., 2016). Tan et al. further provided evidence that this neural circuitry in mice is involved in the development of novel preference: when a stimulus was paired with chemo-genetic activation of cNTS proenkephaline-neurons, it became the preferred stimulus, thus less sweet solutions were preferred over sweeter ones, while silencing their synaptic activity prevented the development of preference (Tan et al., 2020). However, non-caloric sweeteners failed to activate the post-oral reward circuitry and to induce incretin hormone release, that mediates CPIR and satiety signals (for review Pepino and Bourne, 2011; Low et al., 2014). The uncoupling of gustatory signal and metabolic value, that occurs with non-caloric sweeteners, seems to alter reward and satiation responses also in human (for review Han et al., 2019). This may explain some adverse effects of noncaloric sweeteners and why they are not so effective in reducing weight (Swithers and Davidson, 2008; Lohner et al., 2017). In summary, visceral signals regulate feeding independently of the sweet taste receptor and its downstream signaling (Araujo et al., 2008; Ren et al., 2010; Oliveira-Maia et al., 2012; Tan et al., 2020). Thus, although post-oral sugar sensing does not convey taste perception, it is important to develop preference and it activates also neurons in the cortical region responsible for gustation. Indeed, activation of the dorsal insula is required to develop sugar preference in ageusic mice (TRPM5-knockout) with a conditioning protocol (Oliveira-Maia et al., 2012). Recent evidence suggests that sweetness and nutritional signals engage distinct brain networks, to motivate ingestion, both in mice and in humans (Tellez et al., 2016; Thanarajah et al., 2019).

Indeed, a recent study in healthy subjects combined fMRI and PET imaging to show that orosensory and post-ingestive mechanisms underly two distinct peaks in dopamine and recruit segregated brain circutries. The first dopaminergic response involved the dorsal striatum, the mesolimbic system, the orosensory pathways and areas participating in reward value signaling, while the second, delayed response was visible in distinct regions, such as the amygdala and the caudate nucleus (Thanarajah et al., 2019). In mice, sweet tasting stimulated dopamine release in the ventral striatum, via projection of the ventral tegmental area, while nutritional visceral sensing induced dopamine release in the dorsal striatum from the Substantia Nigra pars compacta neurons (SNpc). Thus, mesolimbic and nigrostriatal pathways detected taste and food energy, respectively (Tellez et al., 2016). However, the level of dopamine released in both regions was dependent on glucose oxidation rates, and glucose induced higher dopamine release compared to isocaloric serine. Thus, carbohydrate-specific preference can develop independently of taste quality or caloric load. Rather, it is associated with the ability of the body to use carbohydrates as a fuel (Ren et al., 2010). Similar results were obtained in humans with fMRI imaging, showing that glucose metabolism was a critical signal for regulating NAc and hypothalamic responses to food cues, independently of flavor liking (Araujo et al., 2013). However, the exact pathway linking sweet visceral sensing to dopamine release in the brain still needs to be elucidated in humans.

Recently, a pathway connecting gut-chemosensation to brain reward-circuitries was proposed in mice. It involves vagal afferent fibers originating from the stomach and the duodenum, which project, via the right nodose ganglia, to the ventromedial area of the NTS. At the end, via further projections, the dopaminergic neurons of the SNpc are activated to release dopamine in the dorsal striatum (Han et al., 2018). However, it is unlikely that this pathway is activated by sugars, since subdiaphragmatic vagotomy did not alter the preference to glucose ( $\mathrm{Qu}$ et al., 2019). Rather, the mesenteric portal system, which transports glucose from the proximal intestine to the liver, may be crucially involved in food preference acquisition. Mechanistically, this might involve glucose sensing via SGLT1 and GLUT2 followed by information transmission to upper neural stations (Berthoud, 2004; Zukerman et al., 2013; Sclafani et al., 2016; Zhang et al., 2019). Further, bypass surgery of obese people has brought evidence that the gut-brain axis regulates food reward and motivation to eat also in humans (for review Orellana et al., 2019). In Roux-en-Y gastric bypass (RYGB), a small pouch of the stomach is connected with a distal part of the small intestine. This surgery shows the higher efficacy in inducing large and permanent reductions in body weight. Notably, this is not only due to reduced volume and absorbtion of the ingested food, but also to neural and hormonal changes (Ochner et al., 2011; Goldstone et al., 2016; Kim et al., 2018; Tsouristakis et al., 2019). Presumably, both neural and hormonal mechanisms are responsible for the enhanced intake of healthy food as well as for the selective reduction of high-caloric food preference and of hunger, which are observed in RYGB patients (Nance et al., 2020). It appears, that such behavioral changes have a neural correlate. Indeed, RYGB seems to restore the balance in the dopaminergic reward systems, which is altered by overeating. In obese people, the availability of striatal dopaminergic D2R is reduced (Wang et al., 2001), while several prefrontal cortex 
regions are overactivated upon meal consumption or exposure to food cues (Tomasi and Volkow, 2013) (for review Volkow et al., 2011). Conversely, RYGB reduces prefrontal cortex activation and may restore striatal D2R availability (Hamilton et al., 2018). In summary, postingestive sugar sensing is important for body homeostasis as well as sweet gustation, but the exact mechanisms underlying post-oral learned sugar preference still need to be elucidated.

\section{Brain Glucose Sensing}

Glucose is the preferred brain fuel. Substituting it with lactate, the major metabolic alternative for neurons, specifically impaired neuronal network activities that require high energy expenditure, such as gamma- and theta-oscillations (Hollnagel et al., 2020). Thus, only glucose supports optimal information processing in awake animals. In addition to this, some brain areas have specialized neurons working as "glucose sensors": their firing activity is indeed regulated by extracellular glucose levels. Possibly, these neurons are not activated by intracellular glucose metabolism, but rather by sensing extracellular glucose via the sweet taste receptor (Ren et al., 2009; Kohno, 2017). The genes of the sweet taste receptor subunits, Tas1r2 and Tas1r3, and of the associated G-protein gustducin are active in several mammalian brain regions: most abundantly in the hypothalamus, but also in the hippocampus, the habenula, the cortex and the epithelial intraventricular cells of the choroid plexus (Ren et al., 2009).

The hypothalamus is a major regulator of energy balance, as it regulates food intake and metabolism (Kohno, 2017). Here, the first step in energy regulation, i.e., energy sensing, is executed by direct neuronal glucose sensing: some neurons respond to high glucose with excitation and some with inhibition (Fioramonti et al., 2007). It is still open, if this is directly linked to hunger induction, however, two hypothalamic neuronal populations might be particularly relevant in that context: AgRP (orexigenic neuropeptide Y/agouti-related peptide) and POMC (proopiomelanocortin) neurons located in the arcuate nuclei (ARC). Transition of AgRP neurons from active to inactive states was proportional to calories ingested, driving hunger and promoting food intake (Chen et al., 2016; Beutler et al., 2017). Via multiple downstream relay stations, AgRP neurons control also the neuronal activity in the insula, influencing food salience (Livneh et al., 2017). Conversely, POMC neuron activation led to suppression of appetite and food intake (Aponte et al., 2011). Several mechanisms have been described underlying these effects, some related to glucose metabolism and ATP production, and some independent of it, possibly mediated by the sweet taste receptor (for review see Kohno, 2017). Specifically, in the hypothalamus, T1R2 and T1R3 expression was regulated by the nutritional state: it was increased under food deprivation and decreased upon obesity (Ren et al., 2009). Mimicking this situation in vitro, exposure to a low glucose medium selectively promoted higher T1R2 expression in a mouse hypothalamic neuronal cell line, while hyperglycemic media reduced its expression, independently of glucose metabolism (Ren et al., 2009). The non-caloric sweetener sucralose regulated T1R2 expression as well, confirming a metabolism-independent pathway (Ren et al., 2009). Overall, this suggests that sweet taste receptor expression in hypothalamic neurons is under the control of ligand concentration and energy status. However, the regulation is bidirectional as activation of the sweet taste receptor in the ARC hypothalamic nuclei controls neuronal activity and, thus, food intake. In particular, mainly non-POMC leptine-responsive neurons in mice responded to high glucose and/or sucralose with $\mathrm{Ca}^{2+}$ increase that was mediated by the sweet taste receptor and L-type $\mathrm{Ca}^{2+}$ channels (Kohno et al., 2016). However, in 33\% of these neurons the response was not blocked by gurmarine, which specifically interacts with gustducin to block sweet signal transduction, therefore additional mechanisms may be involved (Kohno et al., 2016). Further studies are required to unravel the neuronal types in the ARC that respond to glucose and their physiological role in controlling hunger and satiety.

In summary, sugars can motivate their consumption independently of their sweet taste. Paring signals arising from the tongue and from the gastrointestinal systems is a way to develop and reinforce preference for sugars. Reinforcement occurs when taste is coupled to nutritional value sensing, assuring that absorption, metabolism and energy production follow gustation.

\section{THE JOURNEY OF UNRAVELING SWEET TASTE}

The field of sweet gustation research can be divided in two eras: before and after the discovery of the sweet taste receptor (Figure 3). The cloning of the sweet taste receptor, which occurred at the beginning of this millenium, was the result of a longstanding research and opened new perspectives, new methods and new approaches (Temussi, 2006; von Molitor et al., 2020c).

However, investigation of sweet taste signal transduction has started already in the 70s (Table 6), long before the sweet taste receptor was identified. These studies revealed the involvement of the cAMP/PKA pathway in sweet transduction in different species (Kurihara and Koyama, 1972; Avenet and Lindemann, 1987; Tonosaki and Funakoshi, 1988). In the 90s, gustducin was discovered (McLaughlin et al., 1992; Takami et al., 1994) and it took further $\sim 10$ years of intensive research to finally unravel the identity of the sweet taste receptor (Bachmanov et al., 2001; Kitagawa et al., 2001; Max et al., 2001; Montmayeur et al., 2001; Nelson et al., 2001; Li et al., 2002). This was followed by a boost of research which progressively uncovered the components of the PLC $\beta 2 / I P 3$ downstream-pathway. This was made possible by the parallel discoveries on bitter-mediated signaling (Table 2). Thus, many assumptions true for bitter transduction were transferred to sweet signaling, even if there were only weak or even contradictory evidences. At some point, it became a kind of common sense that sweet, bitter and umami receptors share a similar intracellular signaling mechanism, called "canonical pathway." Since bitter, sweet and umami receptors were found to be mainly expressed in different subgroups of type II cells, it was proposed that the specificity of the response is assured by the type of taste bud cell activated (Finger, 2005). Furthermore, sweetresponsive taste bud cells were shown to be hard-wired via a 


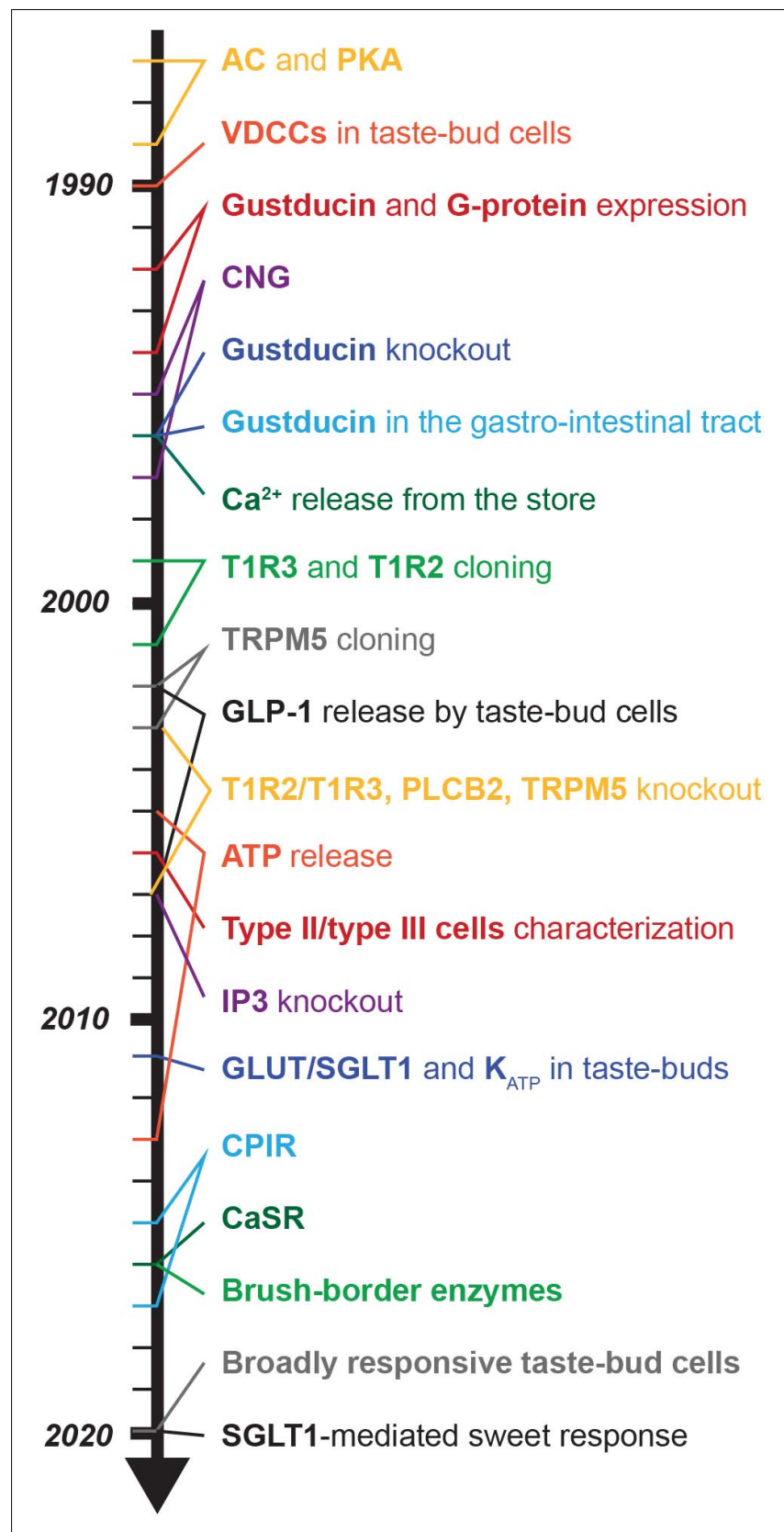

FIGURE 3 | Time-line of the most important findings in sweet taste signaling. The years of the most important publications are marked by lines. The scheme refers to findings related to sweet signaling transduction and focus mainly on the taste bud cells.

specific neural connection to a defined behavioral response (Zhao et al., 2003; Mueller et al., 2005). Thus, the first 10 years from the discovery of the sweet taste receptor were mainly dedicated to the characterization of the cell types (Finger, 2005; Clapp et al., 2006; DeFazio et al., 2006), the downstream molecules (Table 2) and the mechanism of taste bud cells communication (Finger et al., 2005; Huang et al., 2007; Taruno et al., 2013) with afferent fibers and neighboring cells. This reinforced the concept and the importance of the "canonical pathway," but it also marginalized the involvement of the cAMP/PKA-signaling and alternative viewpoints in sugar-mediated responses. A simplified interpretation of sweet taste coding in the taste buds was put forward: one-signaling mechanism and one-cell type (Zhao et al., 2003; Mueller et al., 2005).

However, it became increasingly clear that the picture was much more complicated. Knockout mice models for T1R2/T1R3 (Zhao et al., 2003) and its downstream molecules such as gustducin, PLC $\beta 2$ (Zhang et al., 2003), IP3R (Hisatsune et al., 2007), and TRMP5 (Zhang et al., 2003), verified their functional roles in sweet taste transduction, but residual responses to caloric sugars and not to non-caloric sweeteners (Damak et al., 2003) called for alternative mechanisms responsible for oral-mediated sweet gustation (Glendinning et al., 2015, 2017; Yasumatsu et al., 2020) (for review von Molitor et al., 2020c). In analogy to the mechanisms of glucose-sensing in extraoral tissue, some possible players, such as SGLT1, GLUT2, and $\mathrm{K}_{A T P}$ channels, have raised interest starting from the 2011 (Merigo et al., 2011; Yee et al., 2011), since they are expressed in taste bud cells, however their function is still debated (for review von Molitor et al., 2020c). Nonetheless, a physiological role was proposed for this alternative pathway, as it could be important to recognize the caloric value of food already in the mouth, and to drive CPIR (Glendinning et al., 2015, 2017). At the same time, sweet taste receptor expression was detected in many other organs (for review Yamamoto and Ishimaru, 2013; Laffitte et al., 2014). Since then, most publications have focused on studying taste transduction in extraoral tissues as they may offer new therapeutic possibilities. Accordingly, less projects still focus on fundamental sweet-signaling in taste bud cells, though there are still many open questions, even about the canonical signaling pathway. From the broad extraoral expression of sweet taste receptor, it became evident that the effects of sugars and noncaloric sweeteners are mediated not only by gustation, but also by sweet visceral-sensing (Araujo et al., 2008; Ren et al., 2010; Oliveira-Maia et al., 2012). Thus, for optimal energy homeostasis, glucose sensing in the tongue, intestine, pancreas and the brain need to be coordinated in order to drive the appropriate behavior. Recently, it was proposed that attraction to sugars is not only linked to conscious perception of sweetness, but also to visceral sugar-sensing, being especially relevant for the activation of reward circuitries and for learned sweet-preference (Kim et al., 2018; Han et al., 2019; Gutierrez et al., 2020). If this novel concept can be applied to human, it will challenge the whole interpretation of food-associated diseases, such as obesity and diabetes type II, and it will open new perspectives for their treatment (Neiers et al., 2016). We have also started to understand that non-caloric sweeteners, causing metabolic disregulation, increase the risk of these diseases (Renwick and Molinary, 2010; Pepino, 2015; Lohner et al., 2017). Consistently, extraoral sweet taste receptors are now in the focus of pharmaceutical industry (Sprous and Palmer, 2010). However, we should not stop investigating the sweet-signaling pathways in taste bud cells, since many questions are still open. Furthermore, discovering alternative sweet-sensitive taste mechanisms, their functional role and their ligands, may open the possibility to control energy homeostasis and our eating behavior already at the level of the 
mouth. In this context, it will be important to develop new and more physiological in vitro models to study sweet taste transduction in human.

\section{AUTHOR CONTRIBUTIONS}

EM and TC contributed to conceptualization, writing, and visualization. $\mathrm{KR}, \mathrm{MH}$, and $\mathrm{RR}$ contributed to writing - review and editing and contributed to supervision. RR contributed to project administration. $\mathrm{MH}$ and $\mathrm{RR}$ contributed to funding

\section{REFERENCES}

Abaffy, T., Trubey, K. R., and Chaudhari, N. (2003). Adenylyl cyclase expression and modulation of cAMP in rat taste cells. Am. J. Physiol. Cell Physiol. 284:2002. doi: 10.1152/ajpcell.00556.2002

Abdoul-Azize, S., Selvakumar, S., Sadou, H., Besnard, P., and Khan, N. A. (2014). $\mathrm{Ca} 2+$ signaling in taste bud cells and spontaneous preference for fat: Unresolved roles of CD36 and GPR120. Biochimie 96, 8-13. doi: 10.1016/j.biochi.2013.06. 005

Ahrén, B., and Holst, J. J. (2001). The cephalic insulin response to meal ingestion in humans is dependent on both cholinergic and noncholinergic mechanisms and is important for postprandial glycemia. Diabetes 50, 1030-1038. doi: 10.2337/ diabetes.50.5.1030

Akabas, M. H., Dodd, J., and Al-Awqati, Q. (1988). A bitter substance induces a rise in intracellular calcium in a subpopulation of rat taste cells. Science 242, 1047-1050. doi: 10.1126/science.3194756

Aleman, M. G., Marconi, L. J., Nguyen, N. H., Park, J. M., Patino, M. M., Wang, Y., et al. (2016). The Influence of Assay Design, Blinding, and Gymnema sylvestre on Sucrose Detection by Humans. J. Undergrad. Neurosci. Educ. 15, A18-A23.

Antenucci, R. G., and Hayes, J. E. (2015). Nonnutritive sweeteners are not supernormal stimuli. Int. J. Obes. 39, 254-259. doi: 10.1038/ijo.20 14.109

Aponte, Y., Atasoy, D., and Sternson, S. M. (2011). AGRP neurons are sufficient to orchestrate feeding behavior rapidly and without training. Nat. Neurosci. 14, 351-355. doi: 10.1038/nn.2739

Araujo, I. E. (2011). "Multiple reward layers in food reinforcement," in Neurobiology of Sensation and Reward, ed. J. A. Gottfried (Boca Raton, FL: CRC Press), 263-286.

Araujo, I. E. (2016). Circuit organization of sugar reinforcement. Physiol. Behav. 164, 473-477. doi: 10.1016/j.physbeh.2016.04.041

Araujo, I. E., Ferreira, J. G., Tellez, L. A., Ren, X., and Yeckel, C. W. (2012). The gut-brain dopamine axis: a regulatory system for caloric intake. Physiol. Behav. 106, 394-399. doi: 10.1016/j.physbeh.2012.02.026

Araujo, I. E., Gutierrez, R., Oliveira-Maia, A. J., Pereira, A., Nicolelis, M. A. L. and Simon, S. A. (2006). Neural ensemble coding of satiety states. Neuron 51, 483-494. doi: 10.1016/j.neuron.2006.07.009

Araujo, I. E., Lin, T., Veldhuizen, M. G., and Small, D. M. (2013). Metabolic regulation of brain response to food cues. Curr. Biol. 23, 878-883. doi: 10.1016/ j.cub.2013.04.001

Araujo, I. E., Oliveira-Maia, A. J., Sotnikova, T. D., Gainetdinov, R. R., Caron, M. G., Nicolelis, M. A. L., et al. (2008). Food reward in the absence of taste receptor signaling. Neuron 57, 930-941. doi: 10.1016/j.neuron.2008.01.032

Araujo, I. E., Schatzker, M., and Small, D. M. (2020). Rethinking Food Reward. Annu. Rev. Psychol. 71, 139-164. doi: 10.1146/annurev-psych-122216-011643

Asano-Miyoshi, M., Abe, K., and Emori, Y. (2000). Co-expression of calcium signaling components in vertebrate taste bud cells. Neurosci. Lett. 283, 61-64. doi: 10.1016/S0304-3940(00)00911-3

Ashcroft, F. M. (2005). ATP-sensitive potassium channelopathies: focus on insulin secretion. J. Clin. Invest. 115, 2047-2058. doi: 10.1172/JCI25495

Ashcroft, F. M., Harrison, D. E., and Ashcroft, S. J. H. (1984). Glucose induces closure of single potassium channels in isolated rat pancreatic $\beta$-cells. Nature 312, 446-448. acquisition. All authors have read and agreed to the published version of the manuscript.

\section{FUNDING}

This work was funded by the German Federal Ministry of Education and Research (BMBF) as part of the Innovation Partnership $\mathrm{M}^{2}$ Aind, project $\mathrm{M}^{2}$ OGA (03FH8I02IA) within the framework Starke Fachhochschulen-Impuls für die Region (FHImpuls).

Avenet, P., and Lindemann, B. (1987). Patch-clamp study of isolated taste receptor cells of the frog. J. Membr. Biol. 97, 223-240.

Avery, J. A., Liu, A. G., Ingeholm, J. E., Riddell, C. D., Gotts, S. J., and Martin, A. (2020). Taste Quality Representation in the Human Brain. J. Neurosci. 40, 1042-1052. doi: 10.1523/JNEUROSCI.1751-19.2019

Bachmanov, A. A., Bosak, N. P., Lin, C., Matsumoto, I., Ohmoto, M., Reed, D. R., et al. (2014). Genetics of taste receptors. Curr. Pharm. Des. 20, 2669-2683. doi: 10.2174/13816128113199990566

Bachmanov, A. A., Li, X., Reed, D. R., Ohmen, J. D., Li, S., Chen, Z., et al. (2001). Positional cloning of the mouse saccharin preference (Sac) locus. Chem. Senses 26, 925-933. doi: 10.1093/chemse/26.7.925

Bachmanov, A. A., Reed, D. R., Ninomiya, Y., Inoue, M., Tordoff, M. G., Price, R. A., et al. (1997). Sucrose consumption in mice: major influence of two genetic loci affecting peripheral sensory responses. Mamm. Genome 8, 545-548. doi: $10.1007 / \mathrm{s} 003359900500$

Banik, D. D., Martin, L. E., Freichel, M., Torregrossa, A.-M., et al. (2018). TRPM4 and TRPM5 are both required for normal signaling in taste receptor cells. Proc. Natl. Acad. Sci. U S A. 115, E772-E781. doi: 10.1073/pnas.17188 02115

Barlow, L. A. (2015). Progress and renewal in gustation: New insights into taste bud development. Development 142, 3620-3629. doi: 10.1242/dev.120394

Barretto, R. P. J., Gillis-Smith, S., Chandrashekar, J., Yarmolinsky, D. A., Schnitzer, M. J., Ryba, N. J. P., et al. (2015). The neural representation of taste quality at the periphery. Nature 517, 373-376. doi: 10.1038/nature 13873

Beauchamp, G. K., and Mennella, J. A. (2011). Flavor perception in human infants: development and functional significance. Digestion 83(Suppl. 1), 1-6. doi: 10. $1159 / 000323397$

Béhé, P., DeSimone, J. A., Avenet, P., and Lindemann, B. (1990). Membrane currents in taste cells of the rat fungiform papilla. Evidence for two types of Ca currents and inhibition of K currents by saccharin. J. Gen. Physiol. 96, 1061-1084. doi: 10.1085/jgp.96.5.1061

Bernhardt, S. J., Naim, M., Zehavi, U., and Lindemann, B. (1996). Changes in IP3 and cytosolic Ca2+ in response to sugars and non-sugar sweeteners in transduction of sweet taste in the rat. J. Physiol. 490(Pt 2), 325-336. doi: 10. 1113/jphysiol.1996.sp021147

Berthoud, H. R., Trimble, E. R., Siegel, E. G., Bereiter, D. A., and Jeanrenaud, B. (1980). Cephalic-phase insulin secretion in normal and pancreatic islettransplanted rats. Am. J. Physiol. 238, E336-E340. doi: 10.1152/ajpendo.1980. 238.4.E336

Berthoud, H.-R. (2004). Anatomy and function of sensory hepatic nerves. Anat. Rec. A Discov. Mol. Cell Evol. Biol. 280, 827-835. doi: 10.1002/ar.a.20088

Best, L., Brown, P. D., Sener, A., and Malaisse, W. J. (2010). Electrical activity in pancreatic islet cells: The VRAC hypothesis. Islets 2, 59-64. doi: 10.4161/isl.2.2. 11171

Beutler, L. R., Chen, Y., Ahn, J. S., Lin, Y.-C., Essner, R. A., and Knight, Z. A. (2017). Dynamics of Gut-Brain Communication Underlying Hunger. Neuron 96, 461.e-475.e. doi: 10.1016/j.neuron.2017.09.043

Bezençon, C., Fürholz, A., Raymond, F., Mansourian, R., Métairon, S., Le Coutre, J., et al. (2008). Murine intestinal cells expressing Trpm 5 are mostly brush cells and express markers of neuronal and inflammatory cells. J. Comp. Neurol. 509, 514-525. doi: 10.1002/cne.21768 
Bezençon, C., Le Coutre, J., and Damak, S. (2007). Taste-signaling proteins are coexpressed in solitary intestinal epithelial cells. Chem. Senses 32, 41-49. doi: 10.1093/chemse/bj1034

Borges, M. C., Louzada, M. L., Sá, T. H., Laverty, A. A., Parra, D. C., Garzillo, J. M. F., et al. (2017). Artificially Sweetened Beverages and the Response to the Global Obesity Crisis. PLoS Med. 14:e1002195. doi: 10.1371/journal.pmed. 1002195

Boring, E. G. (1942). Sensation and perception in the history of experimental psychology. New York,NY: Irvington Pub.

Boughter, J. D. Jr., Pumplin, D. W., Yu, C., Christy, R. C., and Smith, D. V. (1997). Differential Expression of $\alpha$-Gustducin in Taste Bud Populations of the Rat and Hamster. J. Neurosci. 17, 2852-2858. doi: 10.1523/JNEUROSCI.17-08-02852. 1997

Bradley, J., Reisert, J., and Frings, S. (2005). Regulation of cyclic nucleotide-gated channels. Curr. Opin. Neurobiol. 15, 343-349. doi: 10.1016/j.conb.2005.05.014

Bray, G. A., and Popkin, B. M. (2014). Dietary sugar and body weight: Have we reached a crisis in the epidemic of obesity and diabetes? health be damned! Pour on the sugar. Diabetes Care 37, 950-956. doi: 10.2337/dc13-2085

Brubaker, P. L. (2017). Species-Dependent Mechanisms Regulating GlucoseDependent GLP-1 Secretion? Diabetes 66, 2063-2065. doi: 10.2337/dbi17-0020

Bundesinstitut für Riskobewertung (2014). Bewertung von Süßstoffen und Zuckeraustauschstoffen. Berlin: Bundesinstitut für Riskobewertung.

Bystrova, M. F., Romanov, R. A., Rogachevskaja, O. A., Churbanov, G. D., and Kolesnikov, S. S. (2010). Functional expression of the extracellular-Ca2+sensing receptor in mouse taste cells. J. Cell Sci. 123, 972-982. doi: 10.1242/ jcs.061879

Canna, A., Prinster, A., Cantone, E., Ponticorvo, S., Russo, A. G., Di Salle, F., et al. (2019). Intensity-related distribution of sweet and bitter taste fMRI responses in the insular cortex. Hum. Brain Mapp. 40, 3631-3646. doi: 10.1002/ hbm. 24621

Capeless, C. G., and Whitney, G. (1995). The genetic basis of preference for sweet substances among inbred strains of mice: preference ratio phenotypes and the alleles of the Sac and dpa loci. Chem. Senses 20, 291-298. doi: 10.1093/chemse/ 20.3.291

Chambers, A. P., Sorrell, J. E., Haller, A., Roelofs, K., Hutch, C. R., Kim, K.-S., et al. (2017). The Role of Pancreatic Preproglucagon in Glucose Homeostasis in Mice. Cell Metab. 25, 927.e-934.e. doi: 10.1016/j.cmet.2017. 02.008

Chambers, E. S., Bridge, M. W., and Jones, D. A. (2009). Carbohydrate sensing in the human mouth: effects on exercise performance and brain activity. J. Physiol. 587, 1779-1794. doi: 10.1113/jphysiol.2008.164285

Chattopadhyay, N., Vassilev, P. M., and Brown, E. M. (eds) (1997). Calcium-sensing receptor: roles in and beyond systemic calcium homeostasis. Biol. Chem. 378, 759-768.

Chaudhari, N., and Roper, S. D. (2010). The cell biology of taste. J. Cell Biol. 190, 285-296. doi: 10.1083/jcb.201003144

Chen, X., Gabitto, M., Peng, Y., Ryba, N. J. P., and Zuker, C. S. (2011). A gustotopic map of taste qualities in the mammalian brain. Science 333, 1262-1266. doi: 10.1126/science. 1204076

Chen, Y., Lin, Y.-C., Zimmerman, C. A., Essner, R. A., and Knight, Z. A. (2016). Hunger neurons drive feeding through a sustained, positive reinforcement signal. Elife 5:18640. doi: 10.7554/eLife.18640

Chikazoe, J., Lee, D. H., Kriegeskorte, N., and Anderson, A. K. (2019). Distinct representations of basic taste qualities in human gustatory cortex. Nat. Commun. 10:1048. doi: 10.1038/s41467-019-08857-z

Choi, H.-J., Cho, Y.-K., Chung, K.-M., and Kim, K.-N. (2016). Differential expression of taste receptors in tongue papillae of DBA mouse. Int. J. Oral Biol. $41,25-32$.

Chow, K. F. (2017). A review of excessive sugar metabolism on oral and general health. Chin. J. Dent. Res. 20, 193-198.

Clapp, T. R., Medler, K. F., Damak, S., Margolskee, R. F., and Kinnamon, S. C. (2006). Mouse taste cells with $\mathrm{G}$ protein-coupled taste receptors lack voltagegated calcium channels and SNAP-25. BMC Biol. 4:7. doi: 10.1186/1741-70074-7

Clapp, T. R., Stone, L. M., Margolskee, R. F., and Kinnamon, S. C. (2001). Immunocytochemical evidence for co-expression of Type III IP3receptor with signaling components of bitter taste transduction. BMC Neurosci. 2:6. doi: $10.1186 / 1471-2202-2-6$
Clapp, T. R., Trubey, K. R., Vandenbeuch, A., Stone, L. M., Margolskee, R. F., Chaudhari, N., et al. (2008). Tonic activity of Galpha-gustducin regulates taste cell responsivity. FEBS Lett. 582, 3783-3787. doi: 10.1016/j.febslet.2008.10.007

Collings, V. B. (1974). Human taste response as a function of locus of stimulation on the tongue and soft palate. Percept. Psychophys. 16, 169-174. doi: 10.3758/ BF03203270

Colsoul, B., Schraenen, A., Lemaire, K., Quintens, R., van Lommel, L., Segal, A., et al. (2010). Loss of high-frequency glucose-induced Ca2+ oscillations in pancreatic islets correlates with impaired glucose tolerance in Trpm5-/- mice. Proc. Natl. Acad. Sci. U S A. 107, 5208-5213. doi: 10.1073/pnas.0913107107

Cook, D. L., and Hales, C. N. (1984). Intracellular ATP directly blocks K+ channels in pancreatic B-cells. Nature 311, 271-273. doi: 10.1038/311271a0

Corson, J. A., and Erisir, A. (2013). Monosynaptic convergence of chorda tympani and glossopharyngeal afferents onto ascending relay neurons in the nucleus of the solitary tract: a high-resolution confocal and correlative electron microscopy approach. J. Comp. Neurol. 521, 2907-2926. doi: 10.1002/cne.23357

Cummings, T. A., Powell, J., and Kinnamon, S. C. (1993). Sweet taste transduction in hamster taste cells: Evidence for the role of cyclic nucleotides. J. Neurophysiol. 70, 2326-2336. doi: 10.1152/jn.1993.70.6.2326

Damak, S., Rong, M., Yasumatsu, K., Kokrashvili, Z., Pérez, C. A., Shigemura, N., et al. (2006). Trpm5 null mice respond to bitter, sweet, and umami compounds. Chem. Senses 31, 253-264. doi: 10.1093/chemse/bjj027

Damak, S., Rong, M., Yasumatsu, K., Kokrashvili, Z., Varadarajan, V., Zou, S., et al. (2003). Detection of sweet and umami taste in the absence of taste receptor T1r3. Science 301, 850-853. doi: 10.1126/science.10 87155

Danilova, V., and Hellekant, G. (2003). Comparison of the responses of the chorda tympani and glossopharyngeal nerves to taste stimuli in C57BL/6J mice. $B M C$ Neurosci. 4:5. doi: 10.1186/1471-2202-4-5

Danilova, V., Damak, S., Margolskee, R. F., and Hellekant, G. (2006). Taste responses to sweet stimuli in alpha-gustducin knockout and wild-type mice. Chem. Senses 31, 573-580. doi: 10.1093/chemse/bjj062

Dastur, D. K. (1961). The relationship between terminal lingual innervation and gustation. A clinical and histological study. Brain 84, 499-513. doi: 10.1093/ brain/84.3.499

Douard, V., and Ferraris, R. P. (2008). Regulation of the fructose transporter GLUT5 in health and disease. Am. J. Physiol. Endocrinol. Metab. 295, E227E237. doi: 10.1152/ajpendo.90245.2008

Dawson, P. A., Mychaleckyj, J. C., Fossey, S. C., Mihic, S. J., Craddock, A. L., and Bowden, D. W. (2001). Sequence and functional analysis of GLUT10: a glucose transporter in the Type 2 diabetes-linked region of chromosome 20q12-13.1. Mol. Genet. Metab. 74, 186-199. doi: 10.1006/mgme.2001.3212

DeFazio, R. A., Dvoryanchikov, G., Maruyama, Y., Kim, J. W., Pereira, E., Roper, S. D., et al. (2006). Separate populations of receptor cells and presynaptic cells in mouse taste buds. J. Neurosci. 26, 3971-3980. doi: 10.1523/JNEUROSCI.051506.2006

Deng, D., and Yan, N. (2016). GLUT, SGLT, and SWEET: Structural and mechanistic investigations of the glucose transporters. Protein Sci. 25, 546-558. doi: $10.1002 /$ pro. 2858

Deuschle, K., Okumoto, S., Fehr, M., Looger, L. L., Kozhukh, L., and Frommer, W. B. (2005). Construction and optimization of a family of genetically encoded metabolite sensors by semirational protein engineering. Protein Sci. 14, 23042314. doi: $10.1110 /$ ps. 051508105

Dhillon, J., Lee, J. Y., and Mattes, R. D. (2017). The cephalic phase insulin response to nutritive and low-calorie sweeteners in solid and beverage form. Physiol. Behav. 181, 100-109. doi: 10.1016/j.physbeh.2017.09.009

DiNicolantonio, J. J., O'Keefe, J. H., and Wilson, W. L. (2018). Sugar addiction: is it real? A narrative review. Br. J. Sports Med. 52, 910-913. doi: 10.1136/bjsports2017-097971

Doblado, M., and Moley, K. H. (2009). Facilitative glucose transporter 9, a unique hexose and urate transporter. Am. J. Physiol. Endocrinol. Metab. 297, E831E835. doi: 10.1152/ajpendo.00296.2009

Dotson, C. D., Geraedts, M. C. P., and Munger, S. D. (2013). Peptide regulators of peripheral taste function. Semin. Cell Dev. Biol. 24, 232-239. doi: 10.1016/j. semcdb.2013.01.004

Dotson, C. D., Roper, S. D., and Spector, A. C. (2005). PLCbeta2-independent behavioral avoidance of prototypical bitter-tasting ligands. Chem. Senses 30, 593-600. doi: 10.1093/chemse/bji053 
Dramane, G., Abdoul-Azize, S., Hichami, A., Vögtle, T., Akpona, S., Chouabe, C., et al. (2012). STIM1 regulates calcium signaling in taste bud cells and preference for fat in mice. J. Clin. Invest. 122, 2267-2282. doi: 10.1172/JCI5 9953

DuBois, G. E. (2016). Molecular mechanism of sweetness sensation. Physiol. Behav. 164, 453-463. doi: 10.1016/j.physbeh.2016.03.015

DuBois, G. E., Orthoefer, F. T., and Walters, D. E. (1991). Sweeteners: Discovery, Molecular Design, and Chemoreception: Developed from a Symposium Sponsored by the Division of Agricultural and Food Chemistry at the 199th National Meeting of the American Chemical Society, Boston, Massachusetts, April 22-27, 1990. Boston: American Chemical Society.

Dušková, M., Macourek, M., Šrámková, M., Hill, M., and Stárka, L. (2013). The role of taste in cephalic phase of insulin secretion. Prague Med. Rep. 114, 222-230. doi: 10.14712/23362936.2014.11

Dutta Banik, D., Benfey, E. D., Martin, L. E., Kay, K. E., Loney, G. C., Nelson, A. R., et al. (2020). A subset of broadly responsive Type III taste cells contribute to the detection of bitter, sweet and umami stimuli. PLoS Genet. 16:e1008925. doi: 10.1371 /journal.pgen. 1008925

Dyer, J., Salmon, K. S. H., Zibrik, L., and Shirazi-Beechey, S. P. (2005). Expression of sweet taste receptors of the T1R family in the intestinal tract and enteroendocrine cells. Biochem. Soc. Trans. 33, 302-305. doi: 10.1042/ BST0330302

Eddy, M. C., Eschle, B. K., Peterson, D., Lauras, N., Margolskee, R. F., and Delay, E. R. (2012). A conditioned aversion study of sucrose and SC45647 taste in TRPM5 knockout mice. Chem. Senses 37, 391-401. doi: 10.1093/ chemse/bjr093

Elliott, R. A., Kapoor, S., and Tincello, D. G. (2011). Expression and distribution of the sweet taste receptor isoforms T1R2 and T1R3 in human and rat bladders. J. Urol. 186, 2455-2462. doi: 10.1016/j.juro.2011.07.083

Eriksson, L., Esberg, A., Haworth, S., Holgerson, P. L., and Johansson, I. (2019). Allelic Variation in Taste Genes Is Associated with Taste and Diet Preferences and Dental Caries. Nutrients 11:nu1107149. doi: 10.3390/nu11071491

Feigin, M. B., Sclafani, A., and Sunday, S. R. (1987). Species differences in polysaccharide and sugar taste preferences. Neurosci. Biobehav. Rev. 11, 231240. doi: 10.1016/S0149-7634(87)80031-3

Feng, X.-H., Liu, X.-M., Zhou, L.-H., Wang, J., and Liu, G.-D. (2008). Expression of glucagon-like peptide- 1 in the taste buds of rat circumvallate papillae. Acta Histochem. 110, 151-154. doi: 10.1016/j.acthis.2007.10.005

Finger, T. E. (2005). Cell types and lineages in taste buds. Chem. Senses 30(Suppl. 1), i54-i55. doi: 10.1093/chemse/bjh110

Finger, T. E., Böttger, B., Hansen, A., Anderson, K. T., Alimohammadi, H., and Silver, W. L. (2003). Solitary chemoreceptor cells in the nasal cavity serve as sentinels of respiration. Proc. Natl. Acad. Sci. U S A. 100, 8981-8986. doi: 10.1073/pnas. 1531172100

Finger, T. E., Danilova, V., Barrows, J., Bartel, D. L., Vigers, A. J., Stone, L., et al. (2005). ATP signaling is crucial for communication from taste buds to gustatory nerves. Science 310, 1495-1499. doi: 10.1126/science.1118435

Fioramonti, X., Contié, S., Song, Z., Routh, V. H., Lorsignol, A., and Pénicaud, L. (2007). Characterization of glucosensing neuron subpopulations in the arcuate nucleus: integration in neuropeptide $\mathrm{Y}$ and pro-opio melanocortin networks? Diabetes 56, 1219-1227. doi: 10.2337/db06-0567

Fletcher, M. L., Ogg, M. C., Lu, L., Ogg, R. J., and Boughter, J. D. (2017). Overlapping Representation of Primary Tastes in a Defined Region of the Gustatory Cortex. J. Neurosci. 37, 7595-7605. doi: 10.1523/JNEUROSCI.064917.2017

Fonseca, E., Lafuente, V., Simon, S. A., and Gutierrez, R. (2018). Sucrose intensity coding and decision-making in rat gustatory cortices. Elife 7:41152. doi: 10. 7554/eLife.41152

Frank, G. K. W., Oberndorfer, T. A., Simmons, A. N., Paulus, M. P., Fudge, J. L., Yang, T. T., et al. (2008). Sucrose activates human taste pathways differently from artificial sweetener. Neuroimage 39, 1559-1569. doi: 10.1016/ j.neuroimage.2007.10.061

Fuller, J. L. (1974). Single-locus control of saccharin preference in mice. J. Hered. 65, 33-36. doi: 10.1093/oxfordjournals.jhered.a108452

Fushan, A. A., Simons, C. T., Slack, J. P., and Drayna, D. (2010). Association between common variation in genes encoding sweet taste signaling components and human sucrose perception. Chem. Senses 35, 579-592. doi: 10.1093/ chemse/bjq063
Galindo-Cuspinera, V., Winnig, M., Bufe, B., Meyerhof, W., and Breslin, P. A. S. (2006). A TAS1R receptor-based explanation of sweet 'water-taste'. Nature 441, 354-357.

Gardner, A., and Carpenter, G. H. (2019). Anatomical stability of human fungiform papillae and relationship with oral perception measured by salivary response and intensity rating. Sci. Rep. 9:9759. doi: 10.1038/s41598-019-46093-z

Geraedts, M. C. P., Takahashi, T., Vigues, S., Markwardt, M. L., Nkobena, A., Cockerham, R. E., et al. (2012). Transformation of postingestive glucose responses after deletion of sweet taste receptor subunits or gastric bypass surgery. Am. J. Physiol. Endocrinol. Metab. 303, E464-E474. doi: 10.1152/ ajpendo.00163.2012

Gilbertson, T. A., and Khan, N. A. (2014). Cell signaling mechanisms of orogustatory detection of dietary fat: Advances and challenges. Progress Lipid Res. 53, 82-92. doi: 10.1016/j.plipres.2013.11.001

Glendinning, J. I., Beltran, F., Benton, L., Cheng, S., Gieseke, J., Gillman, J., et al. (2010). Taste does not determine daily intake of dilute sugar solutions in mice. Am. J. Physiol. Regul. Integr. Comp. Physiol. 299:2010. doi: 10.1152/ajpregu. 00331.2010

Glendinning, J. I., Bloom, L. D., Onishi, M., Zheng, K. H., Damak, S., Margolskee, R. F., et al. (2005). Contribution of alpha-gustducin to taste-guided licking responses of mice. Chem. Senses 30, 299-316. doi: 10.1093/chemse/bji025

Glendinning, J. I., Frim, Y. G., Hochman, A., Lubitz, G. S., Basile, A. J., and Sclafani, A. (2017). Glucose elicits cephalic-phase insulin release in mice by activating KATP channels in taste cells. Am. J. Physiol. Regul. Integr. Comp. Physiol. 312, R597-R610. doi: 10.1152/ajpregu.00433.2016

Glendinning, J. I., Stano, S., Holter, M., Azenkot, T., Goldman, O., Margolskee, R. F., et al. (2015). Sugar-induced cephalic-phase insulin release is mediated by a T1r2+T1r3-independent taste transduction pathway in mice. Am. J. Physiol. Regul. Integr. Comp. Physiol. 309, R552-R560. doi: 10.1152/ajpregu.00056.2015

Goldfine, I. D., Ryan, W. G., and Schwartz, T. B. (1969). The effect of glucola, diet cola and water ingestion on blood glucose and plasma insulin. Proc. Soc. Exp. Biol. Med. 131, 329-330. doi: 10.3181/00379727-131-33870

Goldstone, A. P., Miras, A. D., Scholtz, S., Jackson, S., Neff, K. J., Pénicaud, L., et al. (2016). Link Between Increased Satiety Gut Hormones and Reduced Food Reward After Gastric Bypass Surgery for Obesity. J. Clin. Endocrinol. Metab. 101, 599-609. doi: 10.1210/jc.2015-2665

Gong, T., Wei, Q., Mao, D., and Shi, F. (2016). Expression patterns of taste receptor type 1 subunit 3 and $\alpha$-gustducin in the mouse testis during development. Acta Histochem. 118, 20-30. doi: 10.1016/j.acthis.2015.11.001

Gutierrez, R., Fonseca, E., and Simon, S. A. (2020). The neuroscience of sugars in taste, gut-reward, feeding circuits, and obesity. Cell Mol. Life Sci. 77, 3469-3502. doi: 10.1007/s00018-020-03458-2

Haase, L., Cerf-Ducastel, B., and Murphy, C. (2008). Cortical Activation in Response to Pure Taste Stimuli During the Physiological States of Hunger and Satiety. Neuroimage 44, 1008-1021. doi: 10.1016/j.neuroimage.2008.09.044

Hacker, K., and Medler, K. F. (2008). Mitochondrial calcium buffering contributes to the maintenance of Basal calcium levels in mouse taste cells. J. Neurophysiol. 100, 2177-2191. doi: 10.1152/jn.90534.2008

Hamilton, J., Swenson, S., Hajnal, A., and Thanos, P. K. (2018). Roux-en-Y gastric bypass surgery normalizes dopamine D1, D2, and DAT levels. Synapse 2018:22058. doi: 10.1002/syn.22058

Han, P., Bagenna, B., and Fu, M. (2019). The sweet taste signalling pathways in the oral cavity and the gastrointestinal tract affect human appetite and food intake: a review. Int. J. Food Sci. Nutr. 70, 125-135. doi: 10.1080/09637486.2018.1492522

Han, W., Tellez, L. A., Perkins, M. H., Perez, I. O., Qu, T., Ferreira, J., et al. (2018). A Neural Circuit for Gut-Induced Reward. Cell 175, 665.e-678.e. doi: 10.1016/j.cell.2018.08.049

Hanig, D. P. (1901). Zur Psychophysik des Geschmackssinnes. Wiesloch: Engelmann.

Hass, N., Schwarzenbacher, K., and Breer, H. (2007). A cluster of gustducinexpressing cells in the mouse stomach associated with two distinct populations of enteroendocrine cells. Histochem. Cell Biol. 128, 457-471.

Hass, N., Schwarzenbacher, K., and Breer, H. (2010). T1R3 is expressed in brush cells and ghrelin-producing cells of murine stomach. Cell Tissue Res. 339, 493-504. doi: 10.1007/s00441-009-0907-6

He, W., Danilova, V., Zou, S., Hellekant, G., Max, M., Margolskee, R. F., et al. (2002). Partial rescue of taste responses of alpha-gustducin null mice by transgenic expression of alpha-transducin. Chem. Senses 27, 719-727. doi: 10. 1093/chemse/27.8.719 
Hellekant, G. (1976). On the gustatory effects of gymnemic acid and miraculin in dog, pig and rabbit. Chem. Senses 2, 85-95. doi: 10.1093/chemse/2.1.85

Hellekant, G., Danilova, V., and Ninomiya, Y. (1997). Primate sense of taste: behavioral and single chorda tympani and glossopharyngeal nerve fiber recordings in the rhesus monkey. Macaca Mulatta. J. Neurophysiol. 77, 978-993. doi: $10.1152 /$ jn. 1997.77.2.978

Hellekant, G., DuBois, G. E., Roberts, T. W., and van der Wel, H. (1988). On the gustatory effect of amiloride in the monkey (Macaca mulatto). Chem. Senses 13, 89-93. doi: 10.1093/chemse/13.1.89

Hevezi, P., Moyer, B. D., Lu, M., Gao, N., White, E., Echeverri, F., et al. (2009). Genome-wide analysis of gene expression in primate taste buds reveals links to diverse processes. PLoS One 4:e6395. doi: 10.1371/journal.pone.0006395

Hisatsune, C., Yasumatsu, K., Takahashi-Iwanaga, H., Ogawa, N., Kuroda, Y., Yoshida, R., et al. (2007). Abnormal taste perception in mice lacking the type 3 inositol 1,4,5-trisphosphate receptor. J. Biol. Chem. 282, 37225-37231. doi: 10.1074/jbc.M705641200

Hochheimer, A., Krohn, M., Rudert, K., Riedel, K., Becker, S., Thirion, C., et al. (2014). Endogenous gustatory responses and gene expression profile of stably proliferating human taste cells isolated from fungiform papillae. Chem. Senses 39, 359-377. doi: 10.1093/chemse/bju009

Höfer, D., Püschel, B., and Drenckhahn, D. (1996). Taste receptor-like cells in the rat gut identified by expression of alpha-gustducin. Proc. Natl. Acad. Sci. U S A. 93, 6631-6634. doi: 10.1073/pnas.93.13.6631

Hollnagel, J.-O., Cesetti, T., Schneider, J., Vazetdinova, A., ValiullinaRakhmatullina, F., Lewen, A., et al. (2020). Lactate Attenuates Synaptic Transmission and Affects Brain Rhythms Featuring High Energy Expenditure. iScience 23:101316. doi: 10.1016/j.isci.2020.101316

Hoon, M. A., Adler, E., Lindemeier, J., Battey, J. F., Ryba, N. J., and Zuker, C. S. (1999). Putative Mammalian Taste Receptors: A Class of Taste-Specific GPCRs with Distinct Topographic Selectivity. Cell 96, 541-551. doi: 10.1016/S00928674(00)80658-3

Hoon, M. A., Northup, J. K., Margolskee, R. F., and Ryba, N. J. (1995). Functional expression of the taste specific G-protein, alpha-gustducin. Biochem. J. 309(Pt 2), 629-636. doi: 10.1042/bj3090629

Huang, L., Shanker, Y. G., Dubauskaite, J., Zheng, J. Z., Yan, W., Rosenzweig, S., et al. (1999). Ggamma13 colocalizes with gustducin in taste receptor cells and mediates IP3 responses to bitter denatonium. Nat. Neurosci. 2, 1055-1062. doi: $10.1038 / 15981$

Huang, S., and Czech, M. P. (2007). The GLUT4 glucose transporter. Cell Metab. 5, 237-252. doi: 10.1016/j.cmet.2007.03.006

Huang, Y.-J., Maruyama, Y., Dvoryanchikov, G., Pereira, E., Chaudhari, N., and Roper, S. D. (2007). The role of pannexin 1 hemichannels in ATP release and cell-cell communication in mouse taste buds. Proc. Natl. Acad. Sci. U S A. 104, 6436-6441. doi: 10.1073/pnas.0611280104

Hwang, L.-D., Lin, C., Gharahkhani, P., Cuellar-Partida, G., Ong, J.-S., An, J., et al. (2019). New insight into human sweet taste: a genome-wide association study of the perception and intake of sweet substances. Am. J. Clin. Nutr. 109, 1724-1737. doi: 10.1093/ajcn/nqz043

Hwang, P. M., Verma, A., Bredt, D. S., and Snyder, S. H. (1990). Localization of phosphatidylinositol signaling components in rat taste cells: Role in bitter taste transduction. Proc. Natl. Acad. Sci. U S A. 87, 7395-7399. doi: 10.1073/pnas.87. 19.7395

Inagaki, N., Gonoi, T., Clement, J. P., Namba, N., Inazawa, J., Gonzalez, G., et al. (1995). Reconstitution of IKATP: an inward rectifier subunit plus the sulfonylurea receptor. Science 270, 1166-1170. doi: 10.1126/science.270.5239. 1166

Jang, H.-J., Kokrashvili, Z., Theodorakis, M. J., Carlson, O. D., Kim, B.-J., Zhou, J., et al. (2007). Gut-expressed gustducin and taste receptors regulate secretion of glucagon-like peptide-1. Proc. Natl. Acad. Sci. U S A. 104, 15069-15074. doi: 10.1073/pnas.0706890104

Janssen, S., Laermans, J., Verhulst, P.-J., Thijs, T., Tack, J., and Depoortere, I. (2011). Bitter taste receptors and $\alpha$-gustducin regulate the secretion of ghrelin with functional effects on food intake and gastric emptying. Proc. Natl. Acad. Sci. US A. 108, 2094-2099. doi: 10.1073/pnas.1011508108

Jiang, P., Cui, M., Zhao, B., Liu, Z., Snyder, L. A., Benard, L. M. J., et al. (2005). Lactisole interacts with the transmembrane domains of human T1R3 to inhibit sweet taste. J. Biol. Chem. 280, 15238-15246. doi: 10.1074/jbc.M414287200
Jie, P. B., Qi, Z. H., Li, Z. Y., Hao, X. S., and Zheng, W. (2015). Chlorogenic acid maintains glucose homeostasis through modulating the expression of SGLT-1, GLUT-2, and PLG in different intestinal segments of Sprague-Dawley rats fed a high-fat diet. Biomed. Environ. Sci. 28, 894-903.

Jowett, A., and Shrestha, R. (1998). Mucosa and taste buds of the human epiglottis. J. Anat. 193(Pt 4), 617-618. doi: 10.1046/j.1469-7580.1998.19340617.x

Just, T., Pau, H. W., Engel, U., and Hummel, T. (2008). Cephalic phase insulin release in healthy humans after taste stimulation? Appetite 51, 622-627. doi: 10.1016/j.appet.2008.04.271

Kampov-Polevoy, A., Garbutt, J. C., and Janowsky, D. (1997). Evidence of preference for a high-concentration sucrose solution in alcoholic men. Am. J. Psychiatry 154, 269-270. doi: 10.1176/ajp.154.2.269

Kaske, S., Krasteva, G., König, P., Kummer, W., Hofmann, T., Gudermann, T., et al. (2007). TRPM5, a taste-signaling transient receptor potential ion-channel, is a ubiquitous signaling component in chemosensory cells. BMC Neurosci. 8:49. doi: 10.1186/1471-2202-8-49

Kendig, D. M., Hurst, N. R., Bradley, Z. L., Mahavadi, S., Kuemmerle, J. F., Lyall, V., et al. (2014). Activation of the umami taste receptor (T1R1/T1R3) initiates the peristaltic reflex and pellet propulsion in the distal colon. Am. J. Physiol. Gastrointest Liver Physiol. 307, G1100-G1107. doi: 10.1152/ajpgi.00251.2014

Kendig, M. D. (2014). Cognitive and behavioural effects of sugar consumption in rodents. Rev. Appet. 80, 41-54. doi: 10.1016/j.appet.2014.04.028

Keskitalo, K., Knaapila, A., Kallela, M., Palotie, A., Wessman, M., Sammalisto, S., et al. (2007). Sweet taste preferences are partly genetically determined: identification of a trait locus on chromosome 16. Am. J. Clin. Nutr. 86, 55-63. doi: $10.1093 /$ ajcn/86.1.55

Kikut-Ligaj, D., and Trzcielińska-Lorych, J. (2015). How taste works: cells, receptors and gustatory perception. Cell Mol. Biol. Lett. 20, 699-716. doi: 10. 1515/cmble-2015-0042

Kim, K.-S., Seeley, R. J., and Sandoval, D. A. (2018). Signalling from the periphery to the brain that regulates energy homeostasis. Nat. Rev. Neurosci. 19, 185-196. doi: $10.1038 / \mathrm{nrn} .2018 .8$

Kim, M.-R., Kusakabe, Y., Miura, H., Shindo, Y., Ninomiya, Y., and Hino, A. (2003). Regional expression patterns of taste receptors and gustducin in the mouse tongue. Biochem. Biophys. Res. Communicat. 312, 500-506. doi: 10.1016/ j.bbrc.2003.10.137

Kitagawa, M., Kusakabe, Y., Miura, H., Ninomiya, Y., and Hino, A. (2001). Molecular genetic identification of a candidate receptor gene for sweet taste. Biochem. Biophys. Res. Commun. 283, 236-242. doi: 10.1006/bbrc.2001.4760

Kochem, M. (2017). Type 1 Taste Receptors in Taste and Metabolism. Ann. Nutr. Metab. 70(Suppl. 3), 27-36. doi: 10.1159/000478760

Kohno, D. (2017). Sweet taste receptor in the hypothalamus: a potential new player in glucose sensing in the hypothalamus. J. Physiol. Sci. 67, 459-465. doi: 10.1007/s12576-017-0535-y

Kohno, D., Koike, M., Ninomiya, Y., Kojima, I., Kitamura, T., and Yada, T. (2016). Sweet Taste Receptor Serves to Activate Glucose- and Leptin-Responsive Neurons in the Hypothalamic Arcuate Nucleus and Participates in Glucose Responsiveness. Front. Neurosci. 10:502. doi: 10.3389/fnins.2016.00502

Kojima, I., and Nakagawa, Y. (2011). The Role of the Sweet Taste Receptor in Enteroendocrine Cells and Pancreatic $\beta$-Cells. Diabetes Metab. J. 35, 451-457. doi: 10.4093/dmj.2011.35.5.451

Kojima, I., Nakagawa, Y., Ohtsu, Y., Hamano, K., Medina, J., and Nagasawa, M. (2015). Return of the glucoreceptor: Glucose activates the glucose-sensing receptor T1R3 and facilitates metabolism in pancreatic $\beta$-cells. J. Diabetes Investig. 6, 256-263. doi: 10.1111/jdi.12304

Kokabu, S., Lowery, J. W., Toyono, T., Sato, T., and Yoda, T. (2017). On the Emerging Role of the Taste Receptor Type 1 (T1R) Family of Nutrient-Sensors in the Musculoskeletal System. Molecules 22:molecules22030469. doi: 10.3390/ molecules 22030469

Kokrashvili, Z., Yee, K. K., Ilegems, E., Iwatsuki, K., Li, Y., Mosinger, B., et al. (2014). Endocrine taste cells. Br. J. Nutr. 111(Suppl. 1), S23-S29. doi: 10.1017/ S0007114513002262

Kolesnikov, S. S., and Margolskee, R. F. (1995). A cyclic-nucleotide-suppressible conductance activated by transducin in taste cells. Nature $376,85-88$. doi: $10.1038 / 376085 \mathrm{a} 0$

Krimm, R. F., Nejad, M. S., Smith, J. C., Miller, I. J., and Beidler, L. M. (1987). The effect of bilateral sectioning of the chorda tympani and the greater superficial 
petrosal nerves on the sweet taste in the rat. Physiol. Behav. 41, 495-501. doi: 10.1016/0031-9384(87)90086-2

Kuhn, C., and Meyerhof, W. (2013). Oligomerization of sweet and bitter taste receptors. Methods Cell Biol. 117, 229-242. doi: 10.1016/B978-0-12-408143-7. 00013-X

Kuhn, C., Bufe, B., Winnig, M., Hofmann, T., Frank, O., Behrens, M., et al. (2004). Bitter taste receptors for saccharin and acesulfame K. J. Neurosci. 24, 10260-10265. doi: 10.1523/JNEUROSCI.1225-04.2004

Kuhre, R. E., Frost, C. R., Svendsen, B., and Holst, J. J. (2015). Molecular mechanisms of glucose-stimulated GLP-1 secretion from perfused rat small intestine. Diabetes 64, 370-382. doi: 10.2337/db14-0807

Kurihara, K., and Koyama, N. (1972). High activity of adenyl cyclase in olfactory and gustatory organs. Biochem. Biophys. Res. Commun. 48, 30-34. doi: 10.1016/ 0006-291X(72)90339-7

Kurosaki, Y., Yano, K., and Kimura, T. (1998). Perfusion cells for studying regional variation in oral mucosal permeability in humans. 2. A specialized transport mechanism in D-glucose absorption exists in dorsum of tongue. J. Pharm. Sci. 87, 613-615. doi: 10.1021/js9703028

Kusakabe, Y., Yamaguchi, E., Tanemura, K., Kameyama, K., Chiba, N., Arai, S., et al. (1998). Identification of two $\alpha$-subunit species of GTP-binding proteins, G $\alpha 15$ and G $\alpha$ q, expressed in rat taste buds. Biochim. Biophys. Acta Mol. Cell Res. 1403, 265-272. doi: 10.1016/S0167-4889(98)00062-7

Kusakabe, Y., Yasuoka, A., Asano-Miyoshi, M., Iwabuchi, K., Matsumoto, I., Arai, S., et al. (2000). Comprehensive study on G protein alpha-subunits in taste bud cells, with special reference to the occurrence of Galphai2 as a major Galpha species. Chem. Senses 25, 525-531. doi: 10.1093/chemse/25.5.525

Laffitte, A., Neiers, F., and Briand, L. (2014). Functional roles of the sweet taste receptor in oral and extraoral tissues. Curr. Opin. Clin. Nutr. Metab. Care 17, 379-385. doi: 10.1097/MCO.0000000000000058

Lapis, T. J., Penner, M. H., and Lim, J. (2016). Humans Can Taste Glucose Oligomers Independent of the hT1R2/hT1R3 Sweet Taste Receptor. Chem. Senses 2016:bjw088. doi: 10.1093/chemse/bjw088

Laskowski, A. I., and Medler, K. F. (2009). Sodium-calcium exchangers contribute to the regulation of cytosolic calcium levels in mouse taste cells. J. Physiol. 587, 4077-4089. doi: 10.1113/jphysiol.2009.173567

Law, J. S., and Henkin, R. I. (1982). Taste bud adenosine -3'5'-monophosphate phosphodiesterase: Activity, subcellular distribution and kinetic parameters. Res. Commun. Chem. Pathol. Pharmacol. 38, 439-452.

Lee, A. A., and Owyang, C. (2017). Sugars, Sweet Taste Receptors, and Brain Responses. Nutrients 9:nu9070653. doi: 10.3390/nu9070653

Lee, R. J., and Cohen, N. A. (2014). Bitter and sweet taste receptors in the respiratory epithelium in health and disease. J. Mol. Med. 92, 1235-1244. doi: 10.1007/s00109-014-1222-6

Lee, R. J., and Cohen, N. A. (2015). Taste receptors in innate immunity. Cell Mol. Life Sci. 72, 217-236. doi: 10.1007/s00018-014-1736-7

Lee, R. J., Kofonow, J. M., Rosen, P. L., Siebert, A. P., Chen, B., Doghramji, L., et al. (2014). Bitter and sweet taste receptors regulate human upper respiratory innate immunity. J. Clin. Invest. 124, 1393-1405. doi: 10.1172/JCI72094

Lee, R. J., Xiong, G., Kofonow, J. M., Chen, B., Lysenko, A., Jiang, P., et al. (2012). T2R38 taste receptor polymorphisms underlie susceptibility to upper respiratory infection. J. Clin. Invest. 122, 4145-4159. doi: 10.1172/ JCI64240

Lemon, C. H. (2015). Perceptual and neural responses to sweet taste in humans and rodents. Chemosens. Percept. 8, 46-52. doi: 10.1007/s12078-015-9177-8

Li, X., Staszewski, L., Xu, H., Durick, K., Zoller, M., and Adler, E. (2002). Human receptors for sweet and umami taste. Proc. Natl. Acad. Sci. U S A. 99, 4692-4696. doi: 10.1073/pnas.072090199

Liem, D. G., and Mennella, J. A. (2002). Sweet and sour preferences during childhood: role of early experiences. Dev. Psychobiol. 41, 388-395. doi: 10.1002/ dev. 10067

Liman, E. R., Zhang, Y. V., and Montell, C. (2014). Peripheral coding of taste. Neuron 81, 984-1000. doi: 10.1016/j.neuron.2014.02.022

Lin, H. C., Doty, J. E., Reedy, T. J., and Meyer, J. H. (1989). Inhibition of gastric emptying by glucose depends on length of intestine exposed to nutrient. Am. J. Physiol. 256, G404-G411. doi: 10.1152/ajpgi.1989.256.2.G404

Lin, W., Ogura, T., Margolskee, R. F., Finger, T. E., and Restrepo, D. (2008). TRPM5-expressing solitary chemosensory cells respond to odorous irritants. J. Neurophysiol. 99, 1451-1460. doi: 10.1152/jn.01195.2007
Lindemann, B. (1996). Taste reception. Physiol. Rev. 76, 719-766. doi: 10.1152/ physrev.1996.76.3.719

Lindemann, B. (1999). Receptor seeks ligand: On the way to cloning the molecular receptors for sweet and bitter taste. Nat. Med. 5, 381-382. doi: 10.1038/7377

Livneh, Y., Ramesh, R. N., Burgess, C. R., Levandowski, K. M., Madara, J. C., Fenselau, H., et al. (2017). Homeostatic circuits selectively gate food cue responses in insular cortex. Nature 546, 611-616. doi: 10.1038/nature22375

Lohner, S., Toews, I., and Meerpohl, J. J. (2017). Health outcomes of non-nutritive sweeteners: analysis of the research landscape. Nutr. J. 16:55. doi: 10.1186/ s12937-017-0278-x

Louchami, K., Best, L., Brown, P., Virreira, M., Hupkens, E., Perret, J., et al. (2012). A new role for aquaporin 7 in insulin secretion. Cell Physiol. Biochem. 29, 65-74. doi: $10.1159 / 000337588$

Louis-Sylvestre, J. (1976). Preabsorptive insulin release and hypoglycemia in rats. Am. J. Physiol. 230, 56-60. doi: 10.1152/ajplegacy.1976.230.1.56

Low, Y. Q., Lacy, K., and Keast, R. (2014). The role of sweet taste in satiation and satiety. Nutrients 6, 3431-3450. doi: 10.3390/nu6093431

Lush, I. E. (1989). The genetics of tasting in mice: VI. Saccharin, acesulfame, dulcin and sucrose. Genet. Res. 53, 95-99. doi: 10.1017/S0016672300027968

Lush, I. E., Hornigold, N., King, P., and Stoye, J. P. (1995). The genetics of tasting in mice VII. Glycine revisited, and the chromosomal location of Sac and Soa. Genet. Res. 66, 167-174. doi: 10.1017/S0016672300034510

Lyall, V., Heck, G. L., Vinnikova, A. K., Ghosh, S., Phan, T.-H. T., Alam, R. I., et al. (2004). The mammalian amiloride-insensitive non-specific salt taste receptor is a vanilloid receptor-1 variant. J. Physiol. 558, 147-159. doi: 10.1113/jphysiol. 2004.065656

Maina, I. W., Workman, A. D., and Cohen, N. A. (2018). The role of bitter and sweet taste receptors in upper airway innate immunity: Recent advances and future directions. World J. Otorhinolaryngol. Head Neck Surg. 4, 200-208. doi: 10.1016/j.wjorl.2018.07.003

Margolskee, R. F. (1993). The molecular biology of taste transduction. Bioessays 15, 645-650. doi: 10.1002/bies.950151003

Margolskee, R. F. (2002). Molecular mechanisms of bitter and sweet taste transduction. J. Biol. Chem. 277, 1-4. doi: 10.1074/jbc.R100054200

Margolskee, R. F., Dyer, J., Kokrashvili, Z., Salmon, K. S. H., Ilegems, E., Daly, K., et al. (2007). T1R3 and gustducin in gut sense sugars to regulate expression of Na+-glucose cotransporter 1. Proc. Natl. Acad. Sci. U S A. 104, 15075-15080. doi: 10.1073/pnas.0706678104

Martin, B., Dotson, C. D., Shin, Y.-K., Ji, S., Drucker, D. J., Maudsley, S., et al. (2009). Modulation of taste sensitivity by GLP-1 signaling in taste buds. Ann. N Y. Acad. Sci. 1170, 98-101. doi: 10.1111/j.1749-6632.2009. 03920.x

Martin, C., Passilly-Degrace, P., Chevrot, M., Ancel, D., Sparks, S. M., Drucker, D. J., et al. (2012). Lipid-mediated release of GLP-1 by mouse taste buds from circumvallate papillae: putative involvement of GPR120 and impact on taste sensitivity. J. Lipid Res. 53, 2256-2265. doi: 10.1194/jlr.M025874

Maruyama, Y., Yasuda, R., Kuroda, M., and Eto, Y. (2012). Kokumi substances, enhancers of basic tastes, induce responses in calcium-sensing receptor expressing taste cells. PLoS One 7:e34489. doi: 10.1371/journal.pone.0 034489

Masubuchi, Y., Nakagawa, Y., Ma, J., Sasaki, T., Kitamura, T., Yamamoto, Y., et al. (2013). A novel regulatory function of sweet taste-sensing receptor in adipogenic differentiation of 3T3-L1 cells. PLoS One 8:e54500. doi: 10.1371/ journal.pone.0054500

Matsumura, K., Chang, B. H.-J., Fujimiya, M., Chen, W., Kulkarni, R. N., Eguchi, Y., et al. (2007). Aquaporin 7 Is a $\beta$-Cell Protein and Regulator of Intraislet Glycerol Content and Glycerol Kinase Activity, $\beta$-Cell Mass, and Insulin Production and Secretion?†. Mol. Cell Biol. 27, 6026-6037. doi: 10.1128/MCB. 00384-07

Matsumura, S., Eguchi, A., Mizushige, T., Kitabayashi, N., Tsuzuki, S., Inoue, K., et al. (2009). Colocalization of GPR120 with phospholipase-C $\beta 2$ and $\alpha$ -gustducin in the taste bud cells in mice. Neurosci. Lett. 450, 186-190. doi: 10.1016/j.neulet.2008.11.056

Matsunami, H., Montmayeur, J. P., and Buck, L. B. (2000). A family of candidate taste receptors in human and mouse. Nature 404, 601-604. doi: 10.1038/ 35007072

Maurer, S., Wabnitz, G. H., Kahle, N. A., Stegmaier, S., Prior, B., Giese, T., et al. (2015). Tasting Pseudomonas aeruginosa Biofilms: Human Neutrophils Express 
the Bitter Receptor T2R38 as Sensor for the Quorum Sensing Molecule N-(3Oxododecanoyl)-1-Homoserine Lactone. Front. Immunol. 6:369. doi: 10.3389/ fimmu.2015.00369

Max, M., Shanker, Y. G., Huang, L., Rong, M., Liu, Z., Campagne, F., et al. (2001). Tas1r3, encoding a new candidate taste receptor, is allelic to the sweet responsiveness locus Sac. Nat. Genet. 28, 58-63. doi: 10.1038/88270

McCaughey, S. A. (2008). The taste of sugars. Neurosci. Biobehav. Rev. 32, 10241043. doi: 10.1016/j.neubiorev.2008.04.002

McLaughlin, S. K., McKinnon, P. J., and Margolskee, R. F. (1992). Gustducin is a taste-cell-specific G protein closely related to the transducins. Nature 357, 563-569. doi: 10.1038/357563a0

McLaughlin, S. K., McKinnon, P. J., Robichon, A., Spickofsky, N., and Margolskee, R. F. (1993). Gustducin and transducin: a tale of two G proteins. Ciba Found Symp. 179, 186-196. doi: 10.1002/9780470514511.ch12

McLaughlin, S. K., McKinnon, P. J., Spickofsky, N., Danho, W., and Margolskee, R. F. (1994). Molecular cloning of G proteins and phosphodiesterases from rat taste cells. Physiol. Behav. 56, 1157-1164. doi: 10.1016/0031-9384(94)90360-3

Medina, A., Nakagawa, Y., Ma, J., Li, L., Hamano, K., Akimoto, T., et al. (2014). Expression of the glucose-sensing receptor T1R3 in pancreatic islet: changes in the expression levels in various nutritional and metabolic states. Endocr. J. 61, 797-805. doi: 10.1507/endocrj.ej14-0221

Medina, J., Nakagawa, Y., Nagasawa, M., Fernandez, A., Sakaguchi, K., Kitaguchi, T., et al. (2016). Positive Allosteric Modulation of the Calcium-sensing Receptor by Physiological Concentrations of Glucose. J. Biol. Chem. 291, 23126-23135. doi: $10.1074 /$ jbc.M116.729863

Medler, K. F. (2015). Calcium signaling in taste cells. Biochim. Biophys. Acta 1853, 2025-2032. doi: 10.1016/j.bbamcr.2014.11.013

Medler, K. F., Margolskee, R. F., and Kinnamon, S. C. (2003). Electrophysiological Characterization of Voltage-Gated Currents in Defined Taste Cell Types of Mice. J. Neurosci. 23, 2608-2617. doi: 10.1523/jneurosci.23-07-02608.2003

Meier, J. J., and Nauck, M. A. (2005). Glucagon-like peptide 1(GLP-1) in biology and pathology. Diabetes Metab. Res. Rev. 21, 91-117. doi: 10.1002/dmrr.538

Merigo, F., Benati, D., Cecchini, M. P., Cristofoletti, M., Osculati, F., and Sbarbati, A. (2009). Amylase expression in taste receptor cells of rat circumvallate papillae. Cell Tissue Res. 336, 411-421. doi: 10.1007/s00441-009-0789-7

Merigo, F., Benati, D., Cristofoletti, M., Osculati, F., and Sbarbati, A. (2011). Glucose transporters are expressed in taste receptor cells. J. Anat. 219, 243-252. doi: 10.1111/j.1469-7580.2011.01385.x

Miki, T., Nagashima, K., Tashiro, F., Kotake, K., Yoshitomi, H., Tamamoto, A., et al. (1998). Defective insulin secretion and enhanced insulin action in KATP channel-deficient mice. Proc. Natl. Acad. Sci. U S A. 95, 10402-10406.

Ming, D., Ruiz-Avila, L., and Margolskee, R. F. (1998). Characterization and solubilization of bitter-responsive receptors that couple to gustducin. Proc. Natl. Acad. Sci. U S A. 95, 8933-8938. doi: 10.1073/pnas.95.15.8933

Misaka, T., Kusakabe, Y., Emori, Y., Gonoi, T., Arai, S., and Abe, K. (1997). Taste buds have a cyclic nucleotide-activated channel, CNGgust. J. Biol. Chem. 272, 22623-22629. doi: 10.1074/jbc.272.36.22623

Miura, H., Nakayama, A., Shindo, Y., Kusakabe, Y., Tomonari, H., and Harada, S. (2007). Expression of gustducin overlaps with that of type III IP3 receptor in taste buds of the rat soft palate. Chem. Senses 32, 689-696. doi: 10.1093/chemse/ bjm036

Miyoshi, M. A., Abe, K., and Emori, Y. (2001). IP(3) receptor type 3 and PLCbeta2 are co-expressed with taste receptors T1R and T2R in rat taste bud cells. Chem. Senses 26, 259-265. doi: 10.1093/chemse/26.3.259

Montmayeur, J. (2002). Receptors for bitter and sweet taste. Curr. Opin. Neurobiol. 12, 366-371. doi: 10.1016/S0959-4388(02)00345-8

Montmayeur, J. P., Liberles, S. D., Matsunami, H., and Buck, L. B. (2001). A candidate taste receptor gene near a sweet taste locus. Nat. Neurosci. 4, 492-498. doi: $10.1038 / 87440$

Moskowitz, H. R., and Klarmann, L. (1975). The tastes of artificial sweetners and their mixtures. Chem. Senses 1, 411-421. doi: 10.1093/chemse/1.4.411

Mueller, K. L., Hoon, M. A., Erlenbach, I., Chandrashekar, J., Zuker, C. S., and Ryba, N. J. P. (2005). The receptors and coding logic for bitter taste. Nature 434, 225-229. doi: 10.1038/nature03352

Naim, M., Ronen, T., Striem, B. J., Levinson, M., and Zehavi, U. (1991). Adenylate cyclase responses to sucrose stimulation in membranes of pig circumvallate taste papillae. Comparat. Biochem. Physiol. Part B Comparat. Biochem. 100, 455-458. doi: 10.1016/0305-0491(91)90203-P
Nakagawa, Y., Nagasawa, M., Mogami, H., Lohse, M., Ninomiya, Y., and Kojima, I. (2013). Multimodal function of the sweet taste receptor expressed in pancreatic $\beta$-cells: generation of diverse patterns of intracellular signals by sweet agonists. Endocr. J. 60, 1191-1206. doi: 10.1507/endocrj.ej13-0282

Nakagawa, Y., Nagasawa, M., Yamada, S., Hara, A., Mogami, H., Nikolaev, V. O., et al. (2009). Sweet taste receptor expressed in pancreatic beta-cells activates the calcium and cyclic AMP signaling systems and stimulates insulin secretion. PLoS One 4:e5106. doi: 10.1371/journal.pone.0005106

Nakagawa, Y., Ohtsu, Y., Nagasawa, M., Shibata, H., and Kojima, I. (2014). Glucose promotes its own metabolism by acting on the cell-surface glucose-sensing receptor T1R3. Endocr. J. 61, 119-131. doi: 10.1507/endocrj.ej13-0431

Nakashima, K., and Ninomiya, Y. (1999). Transduction for sweet taste of saccharin may involve both inositol 1,4,5-trisphosphate and cAMP pathways in the fungiform taste buds in C57BL mice. Cell Physiol. Biochem. 9, 90-98. doi: $10.1159 / 000016305$

Nance, K., Acevedo, M. B., and Pepino, M. Y. (2020). Changes in taste function and ingestive behavior following bariatric surgery. Appetite 146: 104423.

Neiers, F., Canivenc-Lavier, M.-C., and Briand, L. (2016). What Does Diabetes "Taste" Like? Curr. Diab. Rep. 16:49. doi: 10.1007/s11892-016-0746-2

Nelson, G., Chandrashekar, J., Hoon, M. A., Feng, L., Zhao, G., Ryba, N. J. P., et al. (2002). An amino-acid taste receptor. Nature 416, 199-202. doi: 10.1038/ nature726

Nelson, G., Hoon, M. A., Chandrashekar, J., Zhang, Y., Ryba, N. J., and Zuker, C. S. (2001). Mammalian Sweet Taste Receptors. Cell 106, 381-390. doi: 10.1016/ S0092-8674(01)00451-2

Ng, K., Woo, J., Kwan, M., Sea, M., Wang, A., Lo, R., et al. (2004). Effect of age and disease on taste perception. J. Pain Symptom Manage. 28, 28-34. doi: 10.1016/j.jpainsymman.2003.11.007

Niki, M., Jyotaki, M., Yoshida, R., and Ninomiya, Y. (2010). Reciprocal modulation of sweet taste by leptin and endocannabinoids. Results Probl. Cell Differ. 52, 101-114. doi: 10.1007/978-3-642-14426-4_9

Nilsson, B. (1979). Taste acuity of the human palate. III. Studies with taste solutions on subjects in different age groups. Acta Odontol. Scand. 37, 235-252. doi: 10.3109/00016357909027585

Ninomiya, Y., Shigemura, N., Yasumatsu, K., Ohta, R., Sugimoto, K., Nakashima, K., et al. (2002). "Leptin and sweet taste," in Vitamins and Hormones, ed. G. Litwack (Amsterdam: Elsevier), 221-248.

Noel, C., and Dando, R. (2015). The effect of emotional state on taste perception. Appetite 95, 89-95. doi: 10.1016/j.appet.2015. 06.003

Ochner, C. N., Kwok, Y., Conceição, E., Pantazatos, S. P., Puma, L. M., Carnell, S., et al. (2011). Selective reduction in neural responses to high calorie foods following gastric bypass surgery. Ann. Surg. 253, 502-507. doi: 10.1097/SLA. 0b013e318203a289

Ogura, T., Mackay-Sim, A., and Kinnamon, S. C. (1997). Bitter Taste Transduction of Denatonium in the Mudpuppy Necturus maculosus. J. Neurosci. 17, 35803587. doi: 10.1523/JNEUROSCI.17-10-03580.1997

Ogura, T., Margolskee, R. F., and Kinnamon, S. C. (2002). Taste receptor cell responses to the bitter stimulus denatonium involve $\mathrm{Ca} 2+$ influx via storeoperated channels. J. Neurophysiol. 87, 3152-3155. doi: 10.1152/jn.2002.87.6. 3152

Ohla, K., Toepel, U., Le Coutre, J., and Hudry, J. (2012). Visual-gustatory interaction: orbitofrontal and insular cortices mediate the effect of high-calorie visual food cues on taste pleasantness. PLoS One 7:e32434. doi: 10.1371/journal. pone. 0032434

Ohla, K., Yoshida, R., Roper, S. D., Di Lorenzo, P. M., Victor, J. D., Boughter, J. D., et al. (2019). Recognizing Taste: Coding Patterns Along the Neural Axis in Mammals. Chem. Senses 44, 237-247. doi: 10.1093/chemse/ bjz013

Okuda, Y., and Tomita, H. (eds) (1976). Differences in sensitivity to taste on the tongue and in the soft palate. Tokyo: University of Tokyo.

Oliveira-Maia, A. J., Araujo, I. E., Monteiro, C., Workman, V., Galhardo, V., and Nicolelis, M. A. L. (2012). The insular cortex controls food preferences independently of taste receptor signaling. Front. Syst. Neurosci. 6:5. doi: 10. 3389/fnsys.2012.00005

Orellana, E. R., Covasa, M., and Hajnal, A. (2019). Neuro-hormonal mechanisms underlying changes in reward related behaviors following weight loss surgery: 
Potential pharmacological targets. Biochem. Pharmacol. 164, 106-114. doi: 10. 1016/j.bcp.2019.04.004

Oyama, Y., Yamano, H., Ohkuma, A., Ogawara, K., Higaki, K., and Kimura, T. (1999). Carrier-mediated transport systems for glucose in mucosal cells of the human oral cavity. J. Pharm. Sci. 88, 830-834. doi: $10.1021 /$ js $980298 \mathrm{f}$

Ozdener, M. H., Subramaniam, S., Sundaresan, S., Sery, O., Hashimoto, T., Asakawa, Y., et al. (2014). CD36- and GPR120-mediated $\mathrm{Ca}^{2+}$ signaling in human taste bud cells mediates differential responses to fatty acids and is altered in obese mice. Gastroenterology 146, 995-1005. doi: 10.1053/j.gastro.2014.01. 006

Peng, Y., Gillis-Smith, S., Jin, H., Tränkner, D., Ryba, N. J. P., and Zuker, C. S. (2015). Sweet and bitter taste in the brain of awake behaving animals. Nature 527, 512-515. doi: 10.1038/nature15763

Pepino, M. Y. (2015). Metabolic effects of non-nutritive sweeteners. Physiol. Behav. 152, 450-455. doi: 10.1016/j.physbeh.2015.06.024

Pepino, M. Y., and Bourne, C. (2011). Non-nutritive sweeteners, energy balance, and glucose homeostasis. Curr. Opin. Clin. Nutr. Metab. Care 14, 391-395. doi: 10.1097/MCO.0b013e3283468e7e

Perea-Martinez, I., Nagai, T., and Chaudhari, N. (2013). Functional cell types in taste buds have distinct longevities. PLoS One 8:e53399. doi: 10.1371/journal. pone.0053399

Pérez, C. A., Huang, L., Rong, M., Kozak, J. A., Preuss, A. K., Zhang, H., et al. (2002). A transient receptor potential channel expressed in taste receptor cells. Nat. Neurosci. 5, 1169-1176. doi: 10.1038/nn952

Porcu, E., Benz, K. M., Ball, F., Tempelmann, C., Hanke, M., and Noesselt, T. (2020). Macroscopic information-based taste representations in insular cortex are shaped by stimulus concentration. Proc. Natl. Acad. Sci. U S A. 117, 7409-7417. doi: 10.1073/pnas.1916329117

Prawitt, D., Monteilh-Zoller, M. K., Brixel, L., Spangenberg, C., Zabel, B., Fleig, A., et al. (2003). TRPM5 is a transient Ca2+-activated cation channel responding to rapid changes in Ca2+i. Proc. Natl. Acad. Sci. U S A. 100, 15166-15171. doi: 10.1073/pnas.2334624100

Prinster, A., Cantone, E., Verlezza, V., Magliulo, M., Sarnelli, G., Iengo, M., et al. (2017). Cortical representation of different taste modalities on the gustatory cortex: A pilot study. PLoS One 12:e0190164. doi: 10.1371/journal. pone.0190164

Qu, T., Han, W., Niu, J., Tong, J., and Araujo, I. E. (2019). On the roles of the Duodenum and the Vagus nerve in learned nutrient preferences. Appetite 139, 145-151. doi: 10.1016/j.appet.2019.04.014

Rebecchi, M. J., and Pentyala, S. N. (2000). Structure, function, and control of phosphoinositide-specific phospholipase C. Physiol. Rev. 80, 1291-1335. doi: 10.1152/physrev.2000.80.4.1291

Rebello, M. R., and Medler, K. F. (2010). Ryanodine receptors selectively contribute to the formation of taste-evoked calcium signals in mouse taste cells. Eur. J. Neurosci. 32, 1825-1835. doi: 10.1111/j.1460-9568.2010.07463.x

Rebello, M. R., Maliphol, A. B., and Medler, K. F. (2013). Ryanodine Receptors Selectively Interact with L Type Calcium Channels in Mouse Taste Cells. PLoS One 8:e68174. doi: 10.1371/journal.pone.0068174

Reed, D. R., and McDaniel, A. H. (2006). The human sweet tooth. BMC Oral Health 6(Suppl. 1):S17. doi: 10.1186/1472-6831-6-S1-S17

Reimann, F., Habib, A. M., Tolhurst, G., Parker, H. E., Rogers, G. J., and Gribble, F. M. (2008). Glucose sensing in L cells: a primary cell study. Cell Metab. 8, 532-539. doi: 10.1016/j.cmet.2008.11.002

Ren, W., Aihara, E., Lei, W., Gheewala, N., Uchiyama, H., Margolskee, R. F., et al. (2017). Transcriptome analyses of taste organoids reveal multiple pathways involved in taste cell generation. Sci. Rep. 7:4004. doi: 10.1038/s41598-01704099-5

Ren, W., Lewandowski, B. C., Watson, J., Aihara, E., Iwatsuki, K., Bachmanov, A. A., et al. (2014). Single Lgr5- or Lgr6-expressing taste stem/progenitor cells generate taste bud cells ex vivo. Proc. Natl. Acad. Sci. U S A. 111, 16401-16406. doi: 10.1073/pnas.1409064111

Ren, X., Ferreira, J. G., Zhou, L., Shammah-Lagnado, S. J., Yeckel, C. W., and Araujo, I. E. (2010). Nutrient selection in the absence of taste receptor signaling. J. Neurosci. 30, 8012-8023. doi: 10.1523/JNEUROSCI.5749-09.2010

Ren, X., Zhou, L., Terwilliger, R., Newton, S. S., and Araujo, I. E. (2009). Sweet taste signaling functions as a hypothalamic glucose sensor. Front. Integr. Neurosci. 3:12. doi: $10.3389 /$ neuro.07.012.2009
Renwick, A. G., and Molinary, S. V. (2010). Sweet taste receptors, low-energy sweeteners, glucose absorption and insulin release. Br. J. Nutr. 104, 1415-1420. doi: 10.1017/S0007114510002540

Rogachevskaja, O. A., Churbanov, G. D., Bystrova, M. F., Romanov, R. A., and Kolesnikov, S. S. (2011). Stimulation of the extracellular $\mathrm{Ca}^{2+}$-sensing receptor by denatonium. Biochem. Biophys. Res. Commun. 416, 433-436. doi: 10.1016/j. bbrc.2011.11.095

Rolls, E. T., and Baylis, L. L. (1994). Gustatory, olfactory, and visual convergence within the primate orbitofrontal cortex. J. Neurosci. 14, 5437-5452. doi: 10. 1523/JNEUROSCI.14-09-05437.1994

Roper, S. D. (2013). Taste buds as peripheral chemosensory processors. Semin. Cell Dev. Biol. 24, 71-79. doi: 10.1016/j.semcdb.2012.12.002

Roper, S. D., and Chaudhari, N. (2017). Taste buds: Cells, signals and synapses. Nat. Rev. Neurosci. 18:485. doi: 10.1038/nrn.2017.68

Rössler, P., Boekhoff, I., Tareilus, E., Beck, S., Breer, H., and Freitag, J. (2000). G protein betagamma complexes in circumvallate taste cells involved in bitter transduction. Chem. Senses 25, 413-421. doi: 10.1093/chemse/25.4.413

Rössler, P., Kroner, C., Freitag, J., Noè, J., and Breer, H. (1998). Identification of a phospholipase C $\beta$ subtype in rat taste cells. Eur. J. Cell Biol. 77, 253-261. doi: 10.1016/S0171-9335(98)80114-3

Rozengurt, E. (2006). Taste receptors in the gastrointestinal tract. I. Bitter taste receptors and alpha-gustducin in the mammalian gut. Am. J. Physiol. Gastrointest. Liver Physiol. 291, G171-G177. doi: 10.1152/ajpgi.00073.2006

Rozengurt, N., Wu, S. V., Chen, M. C., Huang, C., Sternini, C., and Rozengurt, E. (2006). Colocalization of the alpha-subunit of gustducin with PYY and GLP1 in L cells of human colon. Am. J. Physiol. Gastrointest. Liver Physiol. 291, G792-G802. doi: 10.1152/ajpgi.00074.2006

Rudenga, K., Green, B., Nachtigal, D., and Small, D. M. (2010). Evidence for an Integrated Oral Sensory Module in the Human Anterior Ventral Insula. Chem. Senses 35, 693-703. doi: 10.1093/chemse/bjq068

Ruiz, C. J., Wray, K., Delay, E., Margolskee, R. F., and Kinnamon, S. C. (2003). Behavioral evidence for a role of alpha-gustducin in glutamate taste. Chem. Senses 28, 573-579. doi: 10.1093/chemse/bjg049

Ruiz-Avila, L., McLaughlin, S. K., Wildman, D., McKinnon, P. J., Robichon, A., Spickofsky, N., et al. (1995). Coupling of bitter receptor to phosphodiesterase through transducin in taste receptor cells. Nature 376, 80-85. doi: 10.1038/ 376080a0

Ruiz-Avila, L., Wong, G. T., Damak, S., and Margolskee, R. F. (2001). Dominant loss of responsiveness to sweet and bitter compounds caused by a single mutation in alpha -gustducin. Proc. Natl. Acad. Sci. U S A. 98, 8868-8873. doi: $10.1073 /$ pnas. 151235798

Sabino-Silva, R., Mori, R. C., David-Silva, A., Okamoto, M. M., Freitas, H. S., and Machado, U. F. (2010). The $\mathrm{Na}(+) /$ glucose cotransporters: from genes to therapy. Braz. J. Med. Biol. Res. 43, 1019-1026. doi: 10.1590/s0100879x2010007500115

Sainz, E., Cavenagh, M. M., LopezJimenez, N. D., Gutierrez, J. C., Battey, J. F., Northup, J. K., et al. (2007). The G-protein coupling properties of the human sweet and amino acid taste receptors. Dev. Neurobiol. 67, 948-959. doi: 10.1002/ dneu. 20403

Sainz, E., Korley, J. N., Battey, J. F., and Sullivan, S. L. (2001). Identification of a novel member of the T1R family of putative taste receptors. J. Neurochem. 77, 896-903. doi: 10.1046/j.1471-4159.2001.00292.x

Sakata, I., Park, W.-M., Walker, A. K., Piper, P. K., Chuang, J.-C., OsborneLawrence, S., et al. (2012). Glucose-mediated control of ghrelin release from primary cultures of gastric mucosal cells. Am. J. Physiol. Endocrinol. Metab. 302, E1300-E1310. doi: 10.1152/ajpendo.00041.2012

Samuelsen, C. L., Gardner, M. P. H., and Fontanini, A. (2013). Thalamic contribution to cortical processing of taste and expectation. J. Neurosci. 33, 1815-1827. doi: 10.1523/JNEUROSCI.4026-12.2013

San Gabriel, A., Uneyama, H., Maekawa, T., and Torii, K. (2009). The calciumsensing receptor in taste tissue. Biochem. Biophys. Res. Commun. 378, 414-418. doi: 10.1016/j.bbrc.2008.11.060

Sato, K., Endo, S., and Tomita, H. (2002). Sensitivity of three loci on the tongue and soft palate to four basic tastes in smokers and non-smokers. Acta Otolaryngol. Suppl. 2020, 74-82. doi: 10.1080/00016480260046445

Sbarbati, A., Merigo, F., Benati, D., Tizzano, M., Bernardi, P., and Osculati, F. (2004). Laryngeal chemosensory clusters. Chem. Senses 29, 683-692. doi: 10. 1093/chemse/bjh071 
Scheepers, A., Joost, H.-G., and Schürmann, A. (2004). The glucose transporter families SGLT and GLUT: molecular basis of normal and aberrant function. JPEN J. Parenter Enteral. Nutr. 28, 364-371. doi: 10.1177/ 0148607104028005364

Schiffman, S. S., Diaz, C., and Beeker, T. G. (1986). Caffeine intensities taste of certain sweeteners: Role of adenosine receptor. Pharmacol. Biochem. Behav. 24, 429-432. doi: 10.1016/0091-3057(86)90536-8

Schmidt, S., Joost, H.-G., and Schürmann, A. (2009). GLUT8, the enigmatic intracellular hexose transporter. Am. J. Physiol. Endocrinol. Metab. 296, E614E618. doi: 10.1152/ajpendo.91019.2008

Schirra, J., and Göke, B. (2005). The physiological role of GLP-1 in human: incretin, ileal brake or more? Regul. Pept. 128, 109-115. doi: 10.1016/j.regpep.2004.06. 018

Schoenfeld, M. A., Neuer, G., Tempelmann, C., Schüssler, K., Noesselt, T., Hopf, J.-M., et al. (2004). Functional magnetic resonance tomography correlates of taste perception in the human primary taste cortex. Neuroscience 127, 347-353. doi: 10.1016/j.neuroscience.2004.05.024

Schweiger, K., Grüneis, V., Treml, J., Galassi, C., Karl, C. M., Ley, J. P., et al. (2020). Sweet Taste Antagonist Lactisole Administered in Combination with Sucrose, But Not Glucose, Increases Energy Intake and Decreases Peripheral Serotonin in Male Subjects. Nutrients 12:nu12103133. doi: 10.3390/nu12103133

Sclafani, A., Koepsell, H., and Ackroff, K. (2016). SGLT1 sugar transporter/sensor is required for post-oral glucose appetition. Am. J. Physiol. Regul. Integr. Comp. Physiol. 310, R631-R639. doi: 10.1152/ajpregu.00432.2015

Sclafani, A., Marambaud, P., and Ackroff, K. (2014). Sucrose-conditioned flavor preferences in sweet ageusic T1r3 and Calhm1 knockout mice. Physiol. Behav. 126, 25-29. doi: 10.1016/j.physbeh.2013.12.003

Sclafani, A., Zukerman, S., and Ackroff, K. (2020). Residual Glucose Taste in T1R3 Knockout but not TRPM5 Knockout Mice. Physiol. Behav. 222:112945. doi: 10.1016/j.physbeh.2020.112945

Sclafani, A., Zukerman, S., Glendinning, J. I., and Margolskee, R. F. (2007). Fat and carbohydrate preferences in mice: the contribution of alpha-gustducin and Trpm5 taste-signaling proteins. Am. J. Physiol. Regul. Integr. Comp. Physiol. 293, R1504-R1513. doi: 10.1152/ajpregu.00364.2007

Scott, K. (2005). Taste Recognition: Food for Thought. Neuron 48, 455-464. doi: 10.1016/j.neuron.2005.10.015

Shahbake, M., Hutchinson, I., Laing, D. G., and Jinks, A. L. (2005). Rapid quantitative assessment of fungiform papillae density in the human tongue. Brain Res. 1052, 196-201. doi: 10.1016/j.brainres.2005.06.031

Shigemura, N., Yasumatsu, K., Yoshida, R., Sako, N., Katsukawa, H., Nakashima, K., et al. (2005). The role of the dpa locus in mice. Chem. Senses 30(Suppl. 1), i84-i85. doi: 10.1093/chemse/bjh125

Shin, Y.-J., Park, J.-H., Choi, J.-S., Chun, M.-H., Moon, Y. W., and Lee, M.-Y. (2010). Enhanced expression of the sweet taste receptors and alpha-gustducin in reactive astrocytes of the rat hippocampus following ischemic injury. Neurochem. Res. 35, 1628-1634. doi: 10.1007/s11064-010-0223-2

Shin, Y.-K., Martin, B., Golden, E., Dotson, C. D., Maudsley, S., Kim, W., et al. (2008). Modulation of taste sensitivity by GLP-1 signaling. J. Neurochem. 106, 455-463. doi: 10.1111/j.1471-4159.2008. 05397.x

Shindo, Y., Miura, H., Carninci, P., Kawai, J., Hayashizaki, Y., Ninomiya, Y., et al. (2008). G alpha14 is a candidate mediator of sweet/umami signal transduction in the posterior region of the mouse tongue. Biochem. Biophys. Res. Commun. 376, 504-508. doi: 10.1016/j.bbrc.2008.09.035

Shinozaki, K., Shimizu, Y., Shiina, T., Morita, H., and Takewaki, T. (2008). Relationship between taste-induced physiological reflexes and temperature of sweet taste. Physiol. Behav. 93, 1000-1004. doi: 10.1016/j.physbeh.2008.01.006

Small, D. M. (2012). Flavor is in the brain. Physiol. Behav. 107, 540-552. doi: 10.1016/j.physbeh.2012.04.011

Small, D. M., Jones-Gotman, M., and Dagher, A. (2003). Feeding-induced dopamine release in dorsal striatum correlates with meal pleasantness ratings in healthy human volunteers. Neuroimage 19, 1709-1715. doi: 10.1016/s10538119(03)00253-2

Smeets, P. A. M., Erkner, A., and Graaf, C. (2010). Cephalic phase responses and appetite. Nutr. Rev. 68, 643-655. doi: 10.1111/j.1753-4887.2010.00334.x

Smith, J. C., and Sclafani, A. (2002). Saccharin as a sugar surrogate revisited. Appetite 38, 155-160. doi: 10.1006/appe.2001.0467
Spector, A. C., and Travers, S. P. (2005). The representation of taste quality in the mammalian nervous system. Behav. Cogn. Neurosci. Rev. 4, 143-191. doi: $10.1177 / 1534582305280031$

Spielman, A. I. (1998). Gustducin and its role in taste. J. Dent. Res. 77, 539-544. doi: $10.1177 / 00220345980770040601$

Sprous, D., and Palmer, R. K. (2010). "Chapter 6 - The T1R2/T1R3 Sweet Receptor and TRPM5 Ion Channel: Taste Targets with Therapeutic Potential," in Progress in Molecular Biology and Translational Science: Membrane Proteins as Drug Targets, ed. C. A. Lunn (Florida,FL: Academic Press), 151-208.

Stapleton, J. R., Lavine, M. L., Nicolelis, M. A. L., and Simon, S. A. (2007). Ensembles of gustatory cortical neurons anticipate and discriminate between tastants in a single lick. Front. Neurosci. 1:161-174. doi: 10.3389/neuro.01.1.1. 012.2007

Steensels, S., Vancleef, L., and Depoortere, I. (2016). The Sweetener-Sensing Mechanisms of the Ghrelin Cell. Nutrients 8:nu8120795. doi: 10.3390/ nu8120795

Stein, N., Laing, D. G., and Hutchinson, I. (1994). Topographical differences in sweetness sensitivity in the peripheral gustatory system of adults and children. Dev. Brain Res. 82, 286-292. doi: 10.1016/0165-3806(94)90170-8

Steiner, J. E., Glaser, D., Hawilo, M. E., and Berridge, K. C. (2001). Comparative expression of hedonic impact: affective reactions to taste by human infants and other primates. Neurosci. Biobehav. Rev. 25, 53-74. doi: 10.1016/S01497634(00)00051-8

Stone, L. M., Barrows, J., Finger, T. E., and Kinnamon, S. C. (2007). Expression of T1Rs and gustducin in palatal taste buds of mice. Chem. Senses 32, 255-262. doi: 10.1093/chemse/bjl053

Striem, B. J., Naim, M., and Lindemann, B. (1991). Generation of Cyclic AMP in Taste Buds of the Rat Circumvallate Papilla in Response to Sucrose. Cell Physiol. Biochem. 1, 46-54. doi: 10.1159/000154592

Striem, B. J., Pace, U., Zehavi, U., Naim, M., and Lancet, D. (1989). Sweet tastants stimulate adenylate cyclase coupled to GTP-binding protein in rat tongue membranes. Biochem. J. 260, 121-126. doi: 10.1042/bj2600121

Sukumaran, S. K., Yee, K. K., Iwata, S., Kotha, R., Quezada-Calvillo, R., Nichols, B. L., et al. (2016). Taste cell-expressed $\alpha$-glucosidase enzymes contribute to gustatory responses to disaccharides. Proc. Natl. Acad. Sci. U S A. 113, 6035-6040. doi: 10.1073/pnas. 1520843113

Suzuki, T. (2007). Cellular mechanisms in taste buds. Bull. Tokyo Dent. Coll. 48, 151-161. doi: 10.2209/tdcpublication.48.151

Svendsen, B., Larsen, O., Gabe, M. B. N., Christiansen, C. B., Rosenkilde, M. M., Drucker, D. J., et al. (2018). Insulin Secretion Depends on Intra-islet Glucagon Signaling. Cell Rep. 25, 1127.e-1134.e. doi: 10.1016/j.celrep.2018.10.018

Swithers, S. E., and Davidson, T. L. (2008). A role for sweet taste: calorie predictive relations in energy regulation by rats. Behav. Neurosci. 122, 161-173. doi: 10. 1037/0735-7044.122.1.161

Takai, S., Yasumatsu, K., Inoue, M., Iwata, S., Yoshida, R., Shigemura, N., et al. (2015). Glucagon-like peptide-1 is specifically involved in sweet taste transmission. FASEB J. 29, 2268-2280. doi: 10.1096/fi.14-265355

Takami, S., Getchell, T. V., McLaughlin, S. K., Margolskee, R. F., and Getchell, M. L. (1994). Human taste cells express the G protein $\alpha$-gustducin and neuronspecific enolase. Mol. Brain Res. 22, 193-203. doi: 10.1016/0169-328X(94) 90047-7

Talavera, K., Yasumatsu, K., Voets, T., Droogmans, G., Shigemura, N., Ninomiya, Y., et al. (2005). Heat activation of TRPM5 underlies thermal sensitivity of sweet taste. Nature 438, 1022-1025. doi: 10.1038/nature04248

Tan, H.-E., Sisti, A. C., Jin, H., Vignovich, M., Villavicencio, M., Tsang, K. S., et al. (2020). The gut-brain axis mediates sugar preference. Nature 580, 511-516. doi: 10.1038/s41586-020-2199-7

Taniguchi, K. (2004). Expression of the sweet receptor protein, T1R3, in the human liver and pancreas. J. Vet. Med. Sci. 66, 1311-1314. doi: 10.1292/jvms.66.1311

Tappy, L. (2012). Q\&A:'toxic' effects of sugar: should we be afraid of fructose? BMC Biol. 10:42. doi: 10.1186/1741-7007-10-42

Taruno, A., Vingtdeux, V., Ohmoto, M., Ma, Z., Dvoryanchikov, G., Li, A., et al. (2013). CALHM1 ion channel mediates purinergic neurotransmission of sweet, bitter and umami tastes. Nature 495, 223-226. doi: 10.1038/nature11906

Tatzer, E., Schubert, M. T., Timischl, W., and Simbruner, G. (1985). Discrimination of taste and preference for sweet in premature babies. Early Hum. Dev. 12, 23-30. doi: 10.1016/0378-3782(85)90133-1 
Tellez, L. A., Han, W., Zhang, X., Ferreira, T. L., Perez, I. O., Shammah-Lagnado, S. J., et al. (2016). Separate circuitries encode the hedonic and nutritional values of sugar. Nat. Neurosci. 19, 465-470. doi: 10.1038/nn.4224

Temussi, P. (2006). The history of sweet taste: Not exactly a piece of cake. J. Mol. Recognit. 19, 188-199. doi: 10.1002/jmr.767

Than, T. T., Delay, E. R., and Maier, M. E. (1994). Sucrose threshold variation during the menstrual cycle. Physiol. Behav. 56, 237-239. doi: 10.1016/00319384(94)90189-9

Thanarajah, S. E., Backes, H., DiFeliceantonio, A. G., Albus, K., Cremer, A. L., Hanssen, R., et al. (2019). Food Intake Recruits Orosensory and Post-ingestive Dopaminergic Circuits to Affect Eating Desire in Humans. Cell Metab. 29, 695.e-706.e. doi: 10.1016/j.cmet.2018.12.006

Thorens, B. (2015). GLUT2, glucose sensing and glucose homeostasis. Diabetologia 58, 221-232. doi: 10.1007/s00125-014-3451-1

Tizzano, M., Dvoryanchikov, G., Barrows, J. K., Kim, S., Chaudhari, N., and Finger, T. E. (2008). Expression of Galpha14 in sweet-transducing taste cells of the posterior tongue. BMC Neurosci. 9:110. doi: 10.1186/1471-2202-9110

Tomasi, D., and Volkow, N. D. (2013). Striatocortical pathway dysfunction in addiction and obesity: differences and similarities. Crit. Rev. Biochem. Mol. Biol. 48, 1-19. doi: 10.3109/10409238.2012.735642

Tonosaki, K., and Funakoshi, M. (1988). Cyclic nucleotides may mediate taste transduction. Nature 331, 354-356. doi: 10.1038/331354a0

Tonosaki, K., Hori, Y., Shimizu, Y., and Tonosaki, K. (2007). Relationships between insulin release and taste. Biomed. Res. 28, 79-83.

Toyono, T., Seta, Y., Kataoka, S., Oda, M., and Toyoshima, K. (2011). Differential expression of the glucose transporters in mouse gustatory papillae. Cell Tissue Res. 345, 243-252. doi: 10.1007/s00441-011-1210-x

Travers, S. P., and Norgren, R. (1995). Organization of orosensory responses in the nucleus of the solitary tract of rat. J. Neurophysiol. 73, 2144-2162. doi: 10.1152/jn.1995.73.6.2144

Triantafillou, V., Workman, A. D., Kohanski, M. A., and Cohen, N. A. (2018). Taste Receptor Polymorphisms and Immune Response: A Review of Receptor Genotypic-Phenotypic Variations and Their Relevance to Chronic Rhinosinusitis. Front. Cell Infect. Microbiol. 8:64. doi: 10.3389/fcimb.2018. 00064

Trubey, K. R., Culpepper, S., Maruyama, Y., Kinnamon, S. C., and Chaudhari, N. (2006). Tastants evoke cAMP signal in taste buds that is independent of calcium signaling. Am. J. Physiol. Cell Physiol. 291, C237-C244. doi: 10.1152/ajpcell. 00303.2005

Tsouristakis, A. I., Febres, G., McMahon, D. J., Tchang, B., Conwell, I. M., Tsang, A. J., et al. (2019). Long-Term Modulation of Appetitive Hormones and Sweet Cravings After Adjustable Gastric Banding and Roux-enY Gastric Bypass. OBES Surg. 29, 3698-3705. doi: 10.1007/s11695-01904111-Z

Uchida, Y., and Sato, T. (1997). Changes in outward K+ currents in response to two types of sweeteners in sweet taste transduction of gerbil taste cells. Chem. Senses 22, 163-169. doi: 10.1093/chemse/22.2.163

Usui-Aoki, K., Matsumoto, K., Koganezawa, M., Kohatsu, S., Isono, K., Matsubayashi, H., et al. (2005). Targeted expression of Ip3 sponge and Ip3 dsRNA impaires sugar taste sensation in Drosophila. J. Neurogenet. 19, 123-141. doi: 10.1080/01677060600569713

Vargas, E., Podder, V., and Sepulveda, M. A. C. (2019). Physiology, Glucose Transporter Type 4 (GLUT4). Treasure Island, FL: StatPearls Publishing.

Veldhuizen, M. G., Bender, G., Constable, R. T., and Small, D. M. (2007). Trying to detect taste in a tasteless solution: modulation of early gustatory cortex by attention to taste. Chem. Senses 32, 569-581. doi: 10.1093/chemse/ bjm 025

Ventura, A. K., and Mennella, J. A. (2011). Innate and learned preferences for sweet taste during childhood. Curr. Opin. Clin. Nutr. Metab. Care 14, 379-384. doi: 10.1097/MCO.0b013e328346df65

Volkow, N. D., Wang, G.-J., and Baler, R. D. (2011). Reward, dopamine and the control of food intake: implications for obesity. Trends Cogn. Sci. 15, 37-46. doi: 10.1016/j.tics.2010.11.001

von Molitor, E., Nürnberg, E., Ertongur-Fauth, T., Scholz, P., Riedel, K., Hafner, M., et al. (2020a). Analysis of calcium signaling in live human Tongue cell 3DCultures upon tastant perfusion. Cell Calcium 87:102164. doi: 10.1016/j.ceca. 2020.102164 von Molitor, E., Riedel, K., Hafner, M., Rudolf, R., and Cesetti, T. (2020b). Sensing Senses: Optical Biosensors to Study Gustation. Sensors 20:s20071811. doi: 10. 3390/s20071811

von Molitor, E., Riedel, K., Krohn, M., Rudolf, R., Hafner, M., and Cesetti, T. (2020c). An alternative pathway for sweet sensation: possible mechanisms and physiological relevance. Pflugers Arch. 472, 1667-1691. doi: 10.1007/s00424020-02467-1

Vos, A., Heimberg, H., Quartier, E., Huypens, P., Bouwens, L., Pipeleers, D., et al. (1995). Human and rat beta cells differ in glucose transporter but not in glucokinase gene expression. J. Clin. Invest. 96, 2489-2495. doi: 10.1172/ JCI1 18308

Wang, G.-J., Volkow, N. D., Logan, J., Pappas, N. R., Wong, C. T., Zhu, W., et al. (2001). Brain dopamine and obesity. Lancet 357, 354-357.

Wauson, E. M., Zaganjor, E., Lee, A.-Y., Guerra, M. L., Ghosh, A. B., Bookout, A. L., et al. (2012). The G protein-coupled taste receptor T1R1/T1R3 regulates mTORC1 and autophagy. Mol. Cell 47, 851-862. doi: 10.1016/j.molcel.2012 .08 .001

Wee, M., Tan, V., and Forde, C. (2018). A Comparison of Psychophysical DoseResponse Behaviour across 16 Sweeteners. Nutrients 10:nu10111632. doi: 10. $3390 /$ nu10111632

Westman, E. C. (2002). Is dietary carbohydrate essential for human nutrition? Am. J. Clin. Nutr. 75, 951-953. doi: 10.1093/ajcn/75.5.951

Widmayer, P., Breer, H., and Hass, N. (2011). Candidate chemosensory cells in the porcine stomach. Histochem. Cell Biol. 136, 37-45.

Witt, M. (2019). Anatomy and development of the human taste system. Handb. Clin. Neurol. 164, 147-171. doi: 10.1016/B978-0-444-63855-7.00010-1

Wong, G. T., Gannon, K. S., and Margolskee, R. F. (1996). Transduction of bitter and sweet taste by gustducin. Nature 381, 796-800. doi: 10.1038/381796a0

Workman, A. D., Palmer, J. N., Adappa, N. D., and Cohen, N. A. (2015). The Role of Bitter and Sweet Taste Receptors in Upper Airway Immunity. Curr. Allergy Asthma Rep. 15:72. doi: 10.1007/s11882-015-0571-8

Wright, E. M., Loo, D. D. F., and Hirayama, B. A. (2011). Biology of human sodium glucose transporters. Physiol. Rev. 91, 733-794. doi: 10.1152/physrev. 00055.2009

Wu, A., Dvoryanchikov, G., Pereira, E., Chaudhari, N., and Roper, S. D. (2015). Breadth of tuning in taste afferent neurons varies with stimulus strength. Nat. Commun. 6:8171. doi: 10.1038/ncomms9171

Yamamoto, K., and Ishimaru, Y. (2013). Oral and extra-oral taste perception. Semin. Cell Dev. Biol. 24, 240-246. doi: 10.1016/j.semcdb.2012.08.005

Yamazaki, M., and Sakaguchi, T. (1986). Effects of D-glucose anomers on sweetness taste and insulin release in man. Brain Res. Bull. 17, 271-274. doi: 10.1016/03619230(86)90126-7

Yan, C. H., Hahn, S., McMahon, D., Bonislawski, D., Kennedy, D. W., Adappa, N. D., et al. (2017). Nitric oxide production is stimulated by bitter taste receptors ubiquitously expressed in the sinonasal cavity. Am. J. Rhinol. Allergy 31, 85-92. doi: 10.2500/ajra.2017.31.4424

Yan, W., Sunavala, G., Rosenzweig, S., Dasso, M., Brand, J. G., and Spielman, A. I. (2001). Bitter taste transduced by PLC-beta(2)-dependent rise in IP(3) and alpha-gustducin-dependent fall in cyclic nucleotides. Am. J. Physiol. Cell Physiol. 280, C742-C751. doi: 10.1152/ajpcell.2001.280.4.C742

Yang, H., Wanner, I. B., Roper, S. D., and Chaudhari, N. (1999). An optimized method for in situ hybridization with signal amplification that allows the detection of rare mRNAs. J. Histochem. Cytochem. 47, 431-446. doi: 10.1177/ 002215549904700402

Yasumatsu, K., Ohkuri, T., Yoshida, R., Iwata, S., Margolskee, R. F., and Ninomiya, Y. (2020). Sodium-glucose cotransporter 1 as a sugar taste sensor in mouse tongue. Acta Physiol. 2020:e13529. doi: 10.1111/apha.13529

Yee, K. K., Sukumaran, S. K., Kotha, R., Gilbertson, T. A., and Margolskee, R. F. (2011). Glucose transporters and ATP-gated K+ (KATP) metabolic sensors are present in type 1 taste receptor 3 (T1r3)-expressing taste cells. Proc. Natl. Acad. Sci. U S A. 108, 5431-5436. doi: 10.1073/pnas.1100 495108

Young, R. L., Sutherland, K., Pezos, N., Brierley, S. M., Horowitz, M., Rayner, C. K., et al. (2009). Expression of taste molecules in the upper gastrointestinal tract in humans with and without type 2 diabetes. Gut 58, 337-346. doi: 10.1136/gut. 2008.148932

Zhang, G.-H., Zhang, H.-Y., Wang, X.-F., Zhan, Y.-H., Deng, S.-P., and Qin, Y.M. (2009). The relationship between fungiform papillae density and detection 
threshold for sucrose in the young males. Chem. Senses 34, 93-99. doi: 10.1093/ chemse/bjn059

Zhang, J., Jin, H., Zhang, W., Ding, C., O'Keeffe, S., Ye, M., et al. (2019). Sour Sensing from the Tongue to the Brain. Cell 179, 392.e-402.e. doi: 10.1016/j.cell. 2019.08.031

Zhang, L., Han, W., Lin, C., Li, F., and Araujo, I. E. (2018). Sugar Metabolism Regulates Flavor Preferences and Portal Glucose Sensing. Front. Integr. Neurosci. 12:57. doi: 10.3389/fnint.2018.00057

Zhang, Y., Hoon, M. A., Chandrashekar, J., Mueller, K. L., Cook, B., Wu, D., et al. (2003). Coding of Sweet, Bitter, and Umami Tastes. Cell 112, 293-301. doi: 10.1016/S0092-8674(03)00071-0

Zhao, F.-Q., and Keating, A. (2007). Functional Properties and Genomics of Glucose Transporters. CG 8, 113-128. doi: 10.2174/13892020778 0368187

Zhao, G. Q., Zhang, Y., Hoon, M. A., Chandrashekar, J., Erlenbach, I., Ryba, N. J. P., et al. (2003). The receptors for mammalian sweet and umami taste. Cell 115, 255-266. doi: 10.1016/s0092-8674(03)00844-4

Zhu, X., and Birnbaumer, L. (1996). G protein subunits and the stimulation of phospholipase C by Gs-and Gi-coupled receptors: Lack of receptor selectivity of Galpha(16) and evidence for a synergic interaction between Gbeta gamma and the alpha subunit of a receptor activated G protein. Proc. Natl. Acad. Sci. U S A. 93, 2827-2831. doi: 10.1073/pnas.93. 7.2827
Zhu, X., Gilbert, S., Birnbaumer, M., and Birnbaumer, L. (1994). Dual signaling potential is common among Gs-coupled receptors and dependent on receptor density. Mol. Pharmacol. 46, 460-469.

ZhuGe, R., Roura, E., and Behrens, M. (2020). Editorial: Extra-Oral Taste Receptors: Function, Disease and Evolution. Front. Physiol. 11:607134. doi: 10.3389/fphys.2020.607134

Zukerman, S., Ackroff, K., and Sclafani, A. (2013). Post-oral appetite stimulation by sugars and nonmetabolizable sugar analogs. Am. J. Physiol. Regul. Integr. Comp. Physiol. 305, R840-R853. doi: 10.1152/ajpregu.00297.2013

Conflict of Interest: KR and MK were employed by the company BRAIN-Biotech.

The remaining authors declare that the research was conducted in the absence of any commercial or financial relationships that could be construed as a potential conflict of interest.

Copyright (c) 2021 von Molitor, Riedel, Krohn, Hafner, Rudolf and Cesetti. This is an open-access article distributed under the terms of the Creative Commons Attribution License (CC BY). The use, distribution or reproduction in other forums is permitted, provided the original author(s) and the copyright owner(s) are credited and that the original publication in this journal is cited, in accordance with accepted academic practice. No use, distribution or reproduction is permitted which does not comply with these terms. 